\title{
Revista de Historia del Arte
}

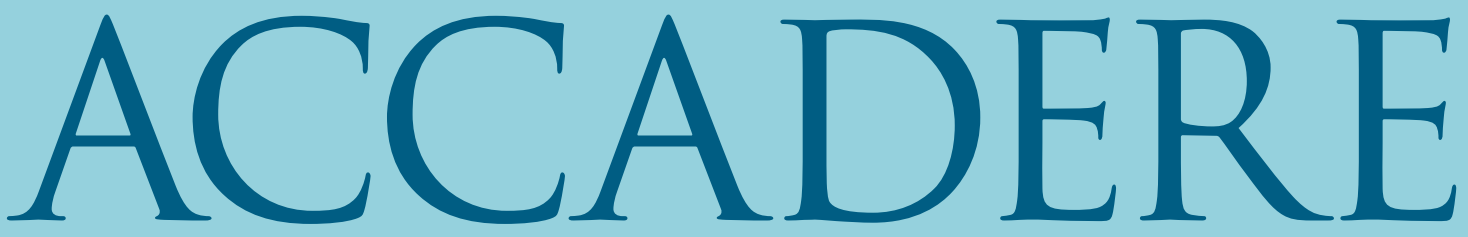

Universidad de La Laguna

$0 \quad 2020$ 
Revista

ACCADERE 


\title{
ACCADERE
}

Revista de Historia del Arte

\section{DIRECTORA}

Noemi Cinelli. Universidad de La Laguna (España) ncinelli@ull.edu.es

\author{
SECRETARIO DE REDACCIÓN
}

Carmelo Vega de la Rosa. Universidad de La Laguna (España) cvega@ull.edu.es

\section{VOCALES}

Gonzalo Pavés Borges. Universidad de La Laguna (España) gpavores@ull.es

Consuelo Soler Lizarazo. Universidad Autónoma de Chile (Chile) lsolerl@uautonoma.cl

Orietta Vittoria Rossi Pinelli. Universitá degli Studi di Roma «La Sapienza» (Italia) orietta.rossipinelli@uniroma1.it Antonio Marrero Alberto. Universidad Adolfo Ibáñez (Chile) antoniomarreroalberto@hotmail.es

\section{RESPONSABLES DE REVISIÓN}

Ivan Sergio. Universidad Autónoma de Chile (Chile) ivan.sergio@uautonoma.cl

Sara Barrios Díaz. Universidad de La Laguna (España) sbarrios@ull.edu.es Cristóbal Moya Díaz. Universidad de La Laguna (España) moyadiazcristobal@gmail.com

\section{CONSEJO ASESOR}

Antonio Albardonedo Freire. Universidad de Sevilla (España) aaf@us.es

Jesús Rojas-Marcos González. Universidad de Sevilla (España) rojasmarcos@us.es

Carmen de Tena Ramírez. Universidad de Sevilla (España) carmendetenaramirez@gmail.com

María de Los Ángeles Fernández Valle. Universidad Pablo de Olavide (Espańa) maferval@upo.es

Claudio Petit Laurent Charpentier. Universidad Católica de Temuco (Chile) claudiopetitlaurent@gmail.com

Alejandra Palafox Menegazzi. Universidad Autónoma de Chile (Chile) BYMENE43@hotmail.com

Ivan Sergio. Universidad Autónoma de Chile (Chile) ivan.sergio@uautonoma.cl

Emilce Nieves Sosa. Universidad Nacional de Cuyo (Argentina) ensr02@gmail.com

Consuelo Soler Lizarazo. Universidad Autónoma de Chile (Chile) lsolerl@uautonoma.cl

Pompeyo Pérez Díaz. Universidad de La Laguna (España) poperez@ull.es

María Inmaculada Rodríguez Moya. Universitat Jaume I (Espańa) mrodrigu@his.uji.es

Victor Mínguez Cornelles. Universitat Jaume I (España) minguez@his.uji.es

Juan Chiva Beltrán. Universitat Jaume I (España) chivaj@his.uji.es

Pedro Zamorano Pérez. Universidad de Talca (Chile) pzamoper@utalca.cl

Carmen Milagros González de Chávez. Universidad de La Laguna (España) cmgonzal@ull.edu.es

Ana María Quesada Acosta. Universidad de La Laguna (Espańa) aquesada@ull.edu.es

Ricardo Anguita Cantero. Universidad de Granada (Espańa)

Valeria Camporesi. Universidad Autónoma de Madrid (España)

Kepa Sojo. Universidad del País Vasco (España)

Esther Torrado Martín-Palomino. Universidad de La Laguna (España) estorra@ull.edu.es

Simonne Teixera. Universidade Estadual do Norte Fluminense Darcy Ribeiro-UENF (Brasil) simonnetex@gmail.com

Aline dos Santos Portilho. Instituto Federal Fluminense-(Brasil) asportilho@gmail.com

Juan Ignácio Brizuela. Universidade Federal da Bahia (Brasil) juanbrizuela.gpc@gmail.com

EDITA

Servicio de Publicaciones de la Universidad de La Laguna Campus Central. 38200 La Laguna. Santa Cruz de Tenerife Tel.: +34922319198

\section{DISEŃO EDITORIAL}

Jaime H. Vera

Javier Torres/Luis C. Espinosa

PREIMPRESIÓN

Servicio de Publicaciones

DOI: https://doi.org/10.25145/j.accadere.2020.00

ISSN: e-2660-9142

Prohibida la reproducción total o parcial de esta obra sin permiso del editor. 


\section{Revista}

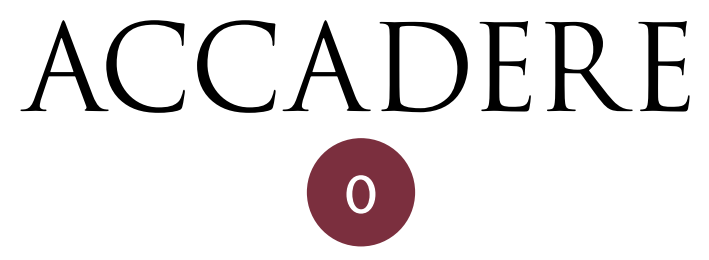


ACCADERE. Revista de Historia del Arte / Universidad de La Laguna. -N. 0 (2020)-. -La Laguna: Universidad, Servicio de Publicaciones, 2020-.

Semestral.

ISSN: e-2660-9142.

1. Arte-Historia -Publicaciones periódicas 2. Arte-Publicaciones periódicas I. Universidad de La Laguna. Servicio de Publicaciones.

$7(05)$

\section{ACERCA DE LA REVISTA}

ACCADERE. Revista de Historia del Arte del Departamento de Historia del Arte y Filosofía de la Universidad de La Laguna nace en 2020 por voluntad de un grupo de profesoras y profesores del Departamento citado. Es una publicación semestral, digital, gratuita, que acepta contribuciones inéditas y originales, que no estén en proceso de revisión en otras revistas. Sus contenidos están sujetos a proceso de double blind peer review, pueden referirse a cualquier rama de los estudios artísticos e históricos artísticos y pueden ser escritos en español, inglés, portugués e italiano. ACCADERE se publica en dos volúmenes anuales, en diciembre y junio. El plazo de entrega de originales para el volumen de diciembre termina el día 30 de julio; y para el volumen de junio acaba el día 30 de enero. Los trabajos recibidos serán valorados por, al menos, dos evaluadores/as externos/as especialistas en cada materia. El/la autor/a recibirá por correo electrónico las pruebas de composición y dispondrá de un plazo de 10 días para su corrección.

Número DOI. A cada artículo publicado en Accadere se le asigna un número DOI.

El DOI de esta revista es https://doi.org/10.25145/j.accadere.

ISSN: e-2660-9142.

\section{DECLARACIÓN DE BUENAS PRÁCTICAS}

ACCADERE. Revista de Historia del Arte reconoce en el European Code of Conduct for Research Integrity de la ALLEA de 2017 el documento de referencia para velar por la integridad y la ética de todo el proceso que lleva la publicación de los números de la revista. Rechaza contribuciones que no sean inéditas y originales, que sean fruto de plagio, que presenten contenidos discriminatorios y que atenten contra los derechos fundamentales de las personas.

\section{AUTORES/AS}

Los/las autores/as someterán a la evaluación en ACCADERE solo y exclusivamente trabajos originales, que no correspondan a traducciones de contribuciones ya publicadas, que reconozcan en cada momento la autoría de las fuentes y de las obras citadas. En caso de utilización de imágenes, fotos u otro material sujeto a derechos de autor, serán los/las autores/as quienes gestionen los permisos necesarios para su reproducción.

$A C C A D E R E$ confía en que el/la autor/a que firma el manuscrito es el/la responsable intelectual del mismo y que asume la responsabilidad pública del contenido del texto. Lo mismo se hará cuando la autoría se comparta entre varios/as firmantes.

\section{REVISORES/AS}

Los/las revisores/as de $A C C A D E R E$ tienen un rol fundamental, ya que deben asistir a los editores en la toma de decisión para publicar o no un manuscrito. Deben mantener confidencialidad respecto al contenido del material revisado y deben obligatoriamente eximirse de la evaluación si hay algún conflicto de interés, tanto positivo como negativo, con los/las autores/as y/o las instituciones relacionadas con el documento a evaluar. 
Las evaluaciones serán objetivas, exentas de juicios y críticas personales hacia los/las autores/as, no deben contener juicios y/o críticas personales infundadas al texto y/o a los/las autores/as, deben reportar eventuales plagios, deben aportar correcciones, aportaciones, observaciones, cuando las haya, justificándolas con claridad y de manera constructiva.

\section{DIRECCIÓN Y EQUIPO EDITORIAL}

La directora y el equipo editorial de $A C C A D E R E$ deciden cuáles manuscritos y en qué orden se publican en los varios números de la revista, mantendrán la total discreción sobre el material recibido y sus autores/as. Velarán por todo el proceso que desde la recepción de las contribuciones lleva a su publicación, garantizado por un proceso de evaluación doble, ciego y por pares especializados/as en la materia objeto de estudio.

\section{REVISIÓN}

Desde la recepción del manuscrito, el proceso de revisión durará entre 1 y 4 meses. La revisión tomará en consideración la novedad del argumento tratado, la aplicación de una metodología correcta para su estudio, la exhaustividad de las fuentes bibliográficas citadas, el dominio de la terminología adecuada, la coherencia entre título, resumen, elaboración, resultados y conclusiones aportadas.

Si un manuscrito es rechazado, no puede ser sometido a una segunda evaluación.

La aceptación de una contribución está limitada por el respeto a los requisitos legales vigentes en materia de difamación, derechos de autor y plagios.

(C) Los trabajos publicados en ACCADERE. Revista de Historia del Arte del Departamento de Historia del Arte y Filosofía de la Universidad de La Laguna son propiedad de sus respectivos autores, quienes conceden a la revista el derecho de primera publicación. Se permite el uso para fines docentes e investigadores de los textos, datos e informaciones contenidos en ellos. Se exige, sin embargo, permiso de los autores para publicarlos en cualquier otro soporte o para utilizarlos, distribuirlos o incluirlos en otros contextos accesibles a terceras personas. En todo caso, es necesario citar la procedencia de cualquier producción parcial o total. 



\section{SUMARIO / CONTENTS}

\section{ARTÍCULOS / ARTICLES}

Dioses grecorromanos en las crónicas de Indias. La mitología clásica en la comprensión del Nuevo Mundo / Greco-Roman Gods in the chronicles of the Indies. Classical mythology in the understanding of the New World

Carolina Valenzuela Matus

Celia Leyton, su pintura indigenista, retrato del patrimonio cultural del pueblo mapuche / Celia Leyton, her indigenous painting, portrait of the Mapuche's cultural heritage

Lorena Villegas, Renzo Vaccaro y Alex Mellado.

Pedro de Obregón y la miniatura toledana a mediados del siglo XVII / Pedro de Obregón and the Toledanian Miniaturism in the middle of the 17 th century Jaime Moraleda Moraleda

Extrañamientos en la ciudad. Del shock urbano a las derivas situacionistas / Extrangement in the city. From urban shock to random situationist derivés Nuria Vallespin Toro.

La iglesia palentina de San Pablo: breve estudio sobre sus retablos (siglos XVXVII) / The Palencia church of San Pablo: brief study on its altarpieces (15th-17th centuries) 

ARTÍCULOS / ARTICLES 



\title{
DIOSES GRECORROMANOS EN LAS CRÓNICAS DE INDIAS. LA MITOLOGÍA CLÁSICA EN LA COMPRENSIÓN DEL NUEVO MUNDO
}

\author{
Carolina Valenzuela Matus \\ Universidad Autónoma de Chile \\ carolina.valenzuela01@uautonoma.cl
}

\section{RESUMEN}

La tradición clásica ha contribuido a consolidar nuevos enfoques historiográficos sobre la América hispana. En este artículo, analizaremos, desde esta tradición, la influencia de la mitología grecolatina en las crónicas escritas por tres autores del siglo xvi: Bernardino de Sahagún, Jerónimo de Mendieta y José de Acosta. Estos religiosos compararon en sus obras a los dioses y héroes grecorromanos con los dioses nativos americanos con el objetivo de acercar a sus lectores a la comprensión del conjunto de creencias de estos pueblos a partir del referente familiar de la mitología clásica, especialmente durante el Renacimiento. Con esto, se busca en parte la comprensión del 'otro', pero nunca se pierde de vista el uso de lo clásico como una herramienta para legitimar la conversión y expansión de la evangelización del continente.

Palabras clave: cronistas de Indias, evangelizadores, Nuevo Mundo, tradición clásica.

\section{GRECO-ROMAN GODS IN THE CHRONICLES OF THE INDIES. CLASSICAL MYTHOLOGY IN THE UNDERSTANDING OF THE NEW WORLD}

\section{Abstract}

The classical tradition has contributed to consolidate new historiographic perspectives in the history of the Americas. In this article, we analyze since this tradition the influence of the Greek and Latin mythology in the chroniclers written by three xvi Century churchmen: Bernardino de Sahagún, Jerónimo de Mendieta and José de Acosta. In their works, the comparison of the Graeco-roman gods and heroes with the gods of the natives had the purpose to bring closer to the readers the comprehension of these beliefs considering the classical mythology as a familiar reference, especially during Renaissance. The objective is the comprehension of the 'otherness'. In addition, the classical is still a useful mean to facilitate conversion and legitimate the evangelization of the continent.

Keywords: Chroniclers of Indies, evangelizers, New World, classical tradition. 


\section{INTRODUCCIÓN}

Desde hace algunas décadas, los estudios sobre la tradición clásica proponen nuevas reflexiones sobre las formas de recepción del legado grecolatino en Hispanoamérica desde una perspectiva que entremezcla los aportes de diversas disciplinas como la filología, el arte, la historia, la filosofía, la antropología y la arqueología. El interés que suscitan estos estudios ha permitido que, en pleno siglo xxI, el legado de la tradición clásica siga más vigente que nunca.

Resulta de especial interés comprender, en términos generales, qué entendemos por legado clásico y cómo se visualiza este legado en la historia de América hispana. De acuerdo con Francisco García Jurado (2016), pueden reconocerse cuatro metáforas que contribuyen a las distintas formas que toma la tradición clásica. La primera sería la metáfora hereditaria de la entrega, donde lo clásico es entendido como algo transmisible o legable de una generación a otra, una tradición que discurre desde el pasado hasta el presente. Una segunda metáfora es la de la inmortalidad, y se refiere a la supervivencia del mundo clásico a través de los siglos, que puede trascender de manera ininterrumpida o bien revivir después de un tiempo. La tercera metáfora es la del contagio, que supone un influjo que discurre en un sentido único, desde el autor más antiguo al más reciente y, por último, la metáfora democrática, donde los lectores de otras épocas realizan nuevas lecturas o recepciones de los clásicos motivadas por diversas circunstancias históricas que permiten crear nuevos sentidos, de allí que los clásicos puedan mantenerse vivos en nuestra sociedad contemporánea.

Para el caso de los cronistas de Indias, es observable cómo muchos de estos escritores fueron influenciados por la lectura de los clásicos grecolatinos en el contexto del Renacimiento (fines del siglo XV y siglo XVI), momento determinante en la revaloración de la Antigüedad clásica en Europa. Esto se manifestó preferentemente a través de la difusión y traducción de textos clásicos, muchos de los cuales habían permanecido ocultos y guardados hasta entonces en diversos monasterios de Europa (Greenblatt 2011) o alojados en las bibliotecas de Constantinopla, zona oriental del Imperio romano e importante centro de conocimiento y circulación de ideas (Reynolds y Wilson 1986). Por otra parte, en la misma ciudad de Roma, se va tomando conciencia de que la Antigüedad, y con ella sus vestigios, se podía confrontar para fundar, con un proceso de imitación y emulación, la nueva Roma (Martín-Esperanza 2018).

En esta etapa se dieron otros importantes procesos como el desarrollo científico y las exploraciones geográficas, que permitieron incorporar al conocimiento de Europa territorios lejanos como África, Asia y América y a los pueblos que habitaban estos continentes, lo que se vio reflejado también en el arte de la época y en el interés por lo novedoso y lo exótico, materializado en la creación de gabinetes de naturaleza que albergaban muestras de naturalia y artificialia procedentes de diversos puntos del globo.

España vivió en esta época la consolidación de la monarquía hispánica y el desarrollo de un importante imperio de ultramar. Por tanto, los clásicos fueron utilizados como referentes artísticos, literarios e históricos para representar simbólicamente su poder reflejado en la comparación de la grandeza y ejemplaridad de los Reyes Católicos con el esplendor del Imperio romano bajo Augusto o la represen- 


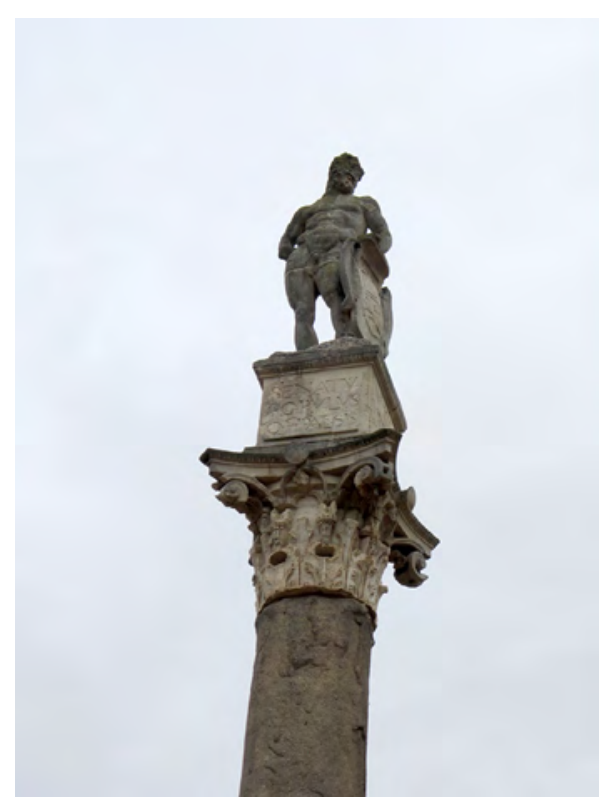

Figura 1. Representación de Carlos V como Hércules. Alameda de Hércules, Sevilla, España. Fotografía de la autora.

tación del emperador Carlos V como un nuevo Hércules (fig. 1) en un momento especialmente floreciente de la expansión geográfica y administrativa de su territorio ultramarino. Los humanistas españoles importaron desde Italia la concepción de un renacer de las letras antiguas y participaron activamente en la misión de recuperar los autores latinos de su país. Se subraya el pasado romano de la Península y se relaciona lo más posible con los romanos, «viendo en Séneca a un compatriota. También intentaron, como Juan de Mena, latinizar el español para demostrar su familiaridad con el latín. Para algunos humanistas como Juan de Lucena, el español estaba incluso más cerca del latín que el italiano» (Biersack 2009).

Con posterioridad a la etapa colonial, en los procesos de independencia de Hispanoamérica se utilizó la estética clásica y también los valores propugnados por esta, para conformar las nuevas naciones. A lo largo de todo el siglo XIX, los clásicos proporcionaron el simbolismo necesario para los ideales de libertad, progreso y civilización en la América hispana difundidos por las nuevas élites políticas y materializados posteriormente en la arquitectura de edificios públicos, estatuarias, discursos, coleccionismo y literatura, entre otros ${ }^{1}$.

1 Véase el más reciente estudio de Ricardo del Molino García, Minerva y los proyectos hispanoamericanos de dominio de la naturaleza en el siglo XIX y principios del siglo XX. El caso de Guate- 
En este artículo analizaremos las influencias clásicas vinculadas a las crónicas de Indias que hemos seleccionado. Sobre estas nos interesa especialmente la influencia de la mitología grecorromana, específicamente a través de sus dioses y héroes. Las crónicas establecieron un paralelo entre estos últimos y los dioses de las culturas nativas con el fin de buscar la comprensión de estas creencias, que muchas veces se contraponían a los tradicionales valores cristianos, pero a partir de modelos ya conocidos por los primeros europeos que llegaron al Nuevo Mundo y en especial por los religiosos dedicados a la evangelización.

\section{CRÓNICAS Y MITOLOGÍA CLÁSICA}

Las crónicas escritas por los diversos conquistadores y evangelizadores españoles que se aventuraron a la conquista de América en el siglo Xvi constituyeron un valioso testimonio de las primeras impresiones y experiencias que los europeos tuvieron en el Nuevo Mundo. Los objetivos que persiguieron estas crónicas fueron muy diversos y no por ello excluyentes; en muchos casos, estuvieron animados por la necesidad de comunicar al monarca lo que sucedía en sus territorios y resaltar así los méritos del cronista en tan arriesgada empresa de ultramar; en otros, se plasmaba la natural curiosidad del ser humano frente a una naturaleza y una población desconocidas para ellos.

En el intento que hicieron los cronistas por acercarse a aquellos aspectos culturales difíciles de comprender para los europeos, utilizaron diversos elementos de la Antigüedad clásica como medio para explicar la vida y las costumbres en las Indias occidentales, entre ellos resulta esencial la mitología, que sirvió para interpretar la religión y a los desconocidos dioses de los nativos a través de patrones ya familiares para la Europa renacentista.

En especial los evangelizadores buscaron en la mitología clásica el punto de acercamiento con las creencias religiosas de los indígenas, y por ello compararon los dioses y mitos de los nativos con los de los antiguos griegos y romanos. Esto es llamado por el antropólogo Fermín del Pino "comparación a efectos compensatorios» nos explica:

Esta comparación entre la religión americana y la de los tiempos clásicos de Europa tiende a compensar el mal efecto que puede producir en el lector europeo la descripción de creencias o ritos extraños, chocantes y a veces horribles (Pino Díaz 1982).

Colocar las creencias religiosas de los nativos al nivel de los clásicos demostraba que estos eran aptos para la cristianización y que sus civilizaciones en nada

mala (1898-1920). Destaca también el proyecto liderado por Mireia Romero titulado «Recepción e influjo de Pompeya y Herculano en España e Iberoamérica». Ministerio de Ciencia, Innovación y Universidades (PGC2018-093509-B-I00). 
desmerecían de las de los antiguos griegos y romanos, quienes volvían a ser un referente de autoridad con el Renacimiento.

La presencia de la mitología clásica en la interpretación de los dioses de los nativos americanos se encuentra de forma abundante en las crónicas, pero por la brevedad de este estudio, analizaremos estas analogías en la obra de tres religiosos: Bernardino de Sahagún, Historia general de las cosas de la Nueva España (c. 1577); Jerónimo de Mendieta, Historia Eclesiástica Indiana (c. 1573-1574); y José de Acosta, Historia Natural y Moral de las Indias (1590). En ellas encontramos ejemplos de cómo los evangelizadores comparan los atributos de los dioses locales con los dioses de la Antigüedad grecorromana. Se busca analizar los casos más significativos, teniendo siempre en perspectiva el hecho de que estos religiosos trabajaron tanto en pos de sus propósitos misionales como en la búsqueda de la comprensión de un otro completamente distinto a lo conocido por ellos hasta ese momento.

2.1. Fray Bernardino de Sahagún (1499-c. 1590): Historia general DE LAS COSAS DE LA NUEVA ESPANA

La Historia general de las cosas de la Nueva España ha sido considerada uno de los mayores antecedentes para el estudio etnográfico de México a pesar de su propósito claramente misional. Su autor, fray Bernardino de Sahagún, estudió en la Universidad de Salamanca, centro importante del Renacimiento europeo en Espańa. Hacia 1527 entró en la orden franciscana y dos años después emprendió su viaje a la Nueva España, en una misión encabezada por fray Antonio de Ciudad Rodrigo. Pasó todo el resto de su vida en México y escribió diversas obras en latín, náhuatl y español. De toda su producción, solo llegó a ver impresa su Psalmodia Christiana y Sermonario de los Santos del año en lengua mexicana (1583). Su obra monumental fue la Historia general de las cosas de la Nueva España, que le tomó más de treinta años de arduo trabajo para nunca verla impresa, ya que la obra se imprimió por primera vez recién en 1829 .

La elaboración de la Historia general fue compleja. En 1570, el trabajo que llevaba haciendo Sahagún junto con sus informantes fue paralizado por falta de fondos y por la escasa ayuda de sus superiores; dos años después, debió asumir la dirección y administración del colegio de Santa Cruz, lo que le dejó poco tiempo para la escritura. En 1575, un decreto real le ordena preparar una versión española de su texto y enviarla a España. No obstante, en 1577, el rey Felipe II emitió un decreto prohibiendo toda nueva investigación de la historia y religión de los naturales (Brading 1991), acontecimiento que condenó su obra a permanecer manuscrita. En México, «el virrey Martín Enríquez trató de adueñarse de los manuscritos de Sahagún, privando así al anciano de toda esperanza de ver algún día impresa la obra de su vida» (Brading 1991).

Una de las características de esta obra fue la complejidad de sus manuscritos debido a la existencia de varias copias de una misma obra en etapas distintas de su elaboración, el estado fragmentario de algunas de ellas y el frecuente cambio de títulos y arreglos. Para Ballesteros, la obra de Sahagún pasaría por tres periodos: 
1. Conocimiento por unos y por otros, incautaciones, envíos a España y dispersión. Algunas partes de la obra manuscrita fueron aprovechadas, con cita o sin ella, por varios autores (siglo XVI y comienzo del XVII). 2. Olvido total y custodia inconsciente en las bibliotecas y archivos a donde habían ido a parar los manuscritos (siglo Xviı y primera mitad del siglo XVIII). 3. Descubrimiento de los manuscritos, valoración de los mismos, copia de uno y otros y comienzo y aumento de las ediciones (segunda mitad los siglos XVIII, xIX y xx) (Ballesteros 1964).

En la obra se reconocen tres códices: el Matritense, el de Tolosa y el Florentino o Sequera. El códice Matritense se compone de la transcripción de los textos en idioma náhuatl compilados por Sahagún. Hacia 1762 una parte fue adquirida por un librero de Madrid y posteriormente vendida una parte a la Biblioteca de la Real Academia de la Historia, y la otra, al Palacio Real. Los libros i y v, que forman parte de estos códices, debieron componerse entre 1569 y 1571. Fueron publicados por Francisco del Paso y Troncoso en 1906. El códice de Tolosa contiene solo el texto en español con algunas variantes. La primera edición, de 1829, estaría basada en este manuscrito conservado en el convento de Tolosa (Navarra) sin que se sepa hasta ahora cómo llegó hasta allí. El códice Florentino o códice Sequera proviene de la obra monumental y manuscrita de Sahagún, que habría sido terminada hacia 1577. Esta obra fue llevada a Espańa por Rodrigo de Sequera en 1580, pero se conserva actualmente en la biblioteca Medicea Laurenziana de esa ciudad (Valenzuela 2016).

Originalmente la obra llevó el título de Historia Universal, título que se perdió con el tiempo dando paso a la denominación de Historia general. El texto en su forma final consistió en dos columnas de texto, una en náhuatl y el otro una «traducción» más o menos libre al castellano y numerosas ilustraciones en la copia más lujosa. Se dividió en doce libros donde se describen los orígenes y atributos de los dioses mexicanos, el calendario, los augurios y sus adivinos, descripciones de los cielos y de la naturaleza, de los reyes y señores, de los discursos moralizantes, así como también de los comerciantes y gente común, concluyendo con oraciones y plegarias y con el relato de la conquista desde la visión de los naturales.

Para David Brading, la obra de Sahagún está lejos de ser una historia, pues es débil al tratar los hechos del pasado, pero sí constituye «una enciclopedia que cubre virtualmente todos los aspectos de la religión, la sociedad y la filosofía natural de los mexicanos» (Brading 1991). Durante su investigación, Sahagún contó con la ayuda de antiguos alumnos suyos del colegio de Santa Cruz de Tlatelolco, quienes, además de conocer la lengua de sus mayores, eran diestros en el manejo del español y el latín.

En la Historia general, se observa claramente que la percepción que tiene el franciscano de la religión de los indígenas está determinada por un paralelismo con los dioses grecorromanos, ya que «para él la religión indígena no es un amasijo informe de supersticiones, sino un verdadero sistema de creencias, como lo fueran en su día el conjunto mitológico greco latino» (Ballesteros 1973). Para Sahagún el paralelo existe y se trata de un conjunto de dioses tan legítimos para los mexicanos como lo fueron los suyos para los hombres de la Antigüedad clásica. Sin embargo, 
que sean considerados legítimos en su contexto no significa que sean tenidos por tales por el franciscano, quien es ante todo un evangelizador comprometido con su causa, que es la implantación de la religión cristiana católica en el Nuevo Mundo. El análisis del legado clásico que aquí se procede a realizar utiliza como base el texto castellano del códice Florentino, en la edición de 1989, preparada por Alfredo López Austin y Josefina García Quintana.

Uno de los primeros aspectos en que se evidencia este legado en la obra lo encontramos en la historia de los primeros pueblos de México. El autor hace referencia a la antigua y célebre ciudad de Tulla, que habría sido destruida hacía ya mil años y que además:

Tuvo la adversa fortuna de Troya. Los chololtecas, que son los que della se escaparon, han tenido la succesión de los romanos, y como los romanos edificaron el Capitolio para su fortaleza, así los chololanos edificaron a mano aquel promontorio que está junto a Cholula. De la manera en que los chololtecas parecen haber tenido la sucesión de Roma, los tlaxcaltecas parecen haber succedido en la fortuna de los cartagineses. Hay grandes señales de las antiguallas destas gentes, como hoy día parece en Tulla y en Tullantzinco, y en un edificio llamado Xuchicalco (Sahagún 1989).

Encontramos también una interesante referencia a una ceremonia realizada en el mes de Izcalli, que es comparada con una práctica propia de la religión romana:

Acabándolos de horadar las orejas [a los niños], llevábanlos los padrinos y madrinas a rodearlos por la llama de un fuego que tenían aparejado para esto, que en latín se dice lustrare, que es ceremonia que la Sagrada Escritura reprende (Sahagún 1989).

Queda claro el conocimiento que Sahagún tenía del lustro, que consistía en una purificación mediante un sacrificio expiatorio, propia de la religión romana. Contreras y otros (1992) explican que se trata de la purificación de las impurezas morales de los hombres, animales y cosas. Esta era realizada por una persona experta y autorizada, distinta a la que era objeto de la ceremonia. Comportaba una serie de ritos que si se cumplían a cabalidad aseguraban que el efecto esperado se diera de forma infalible. Los instrumentos para realizar esta purificación en Roma fueron muy variados, entre ellos encontramos el agua, el fuego, el aire, el laurel, el olivo o la sangre de las víctimas sacrificadas, entre otras. Probablemente, Sahagún encontró alguna vaga similitud entre el rito mexicano que describe y la antigua práctica romana en lo que se refiere a la purificación mediante el fuego.

Asimismo, en la obra de fray Bernardino se encuentran diversos ejemplos de la comparación de los atributos de los dioses locales de México con los dioses de la Antigüedad grecorromana, por ejemplo, el dios Huitzilopuchtli «fue otro Hércules²,

2 Considero interesante señalar un paralelismo en Tácito cuando habla de los germanos señalando: «Recuerdan que entre ellos hubo también un Hércules, y cuando van a combatir lo celebran como el primero de todos los Héroes». Tac. Agr., 3,1. Sin embargo, es difícil identificar las influencias de este autor en Sahagún. 
el cual fue robustísimo, de grandes fuerzas y muy belicoso, gran destruidor de pueblos y matador de gentes» (Sahagún 1989). Del dios Tezcatlipoca dice que es «otro Júpiter», la diosa Chicomecóatl es vista como «otra diosa Ceres» (Sahagún 1989)³. La diosa del agua Chalchiuhtli Icue es «otra Juno» y la diosa de las cosas carnales Tlazultéutl es «otra Venus». Uno de los dioses menores en dignidad, Xiuhtecuhtli, «es otro Vulcán» (Sahagún 1989).

Estos ejemplos confirman el conocimiento que fray Bernardino tiene sobre los textos clásicos, que es lo que permite, según Rodríguez y Castro, que le sea fácil

hallar el paralelismo y la identidad de los dioses greco- romanos con los dioses mexicanos, aun a pesar de que no sabemos se encontrase en la biblioteca del convento de México (Tlatelolco) un libro de mitología greco-latina, los cual nos hace pensar que Fray Bernardino lo llevaba bien aprendido desde España (Rodríguez y Castro 1986).

López Austin observa que en la obra de Sahagún los dioses de los indígenas son de la misma índole que los dioses de los gentiles del Viejo Mundo, lo que queda reafirmado por las comparaciones del libro I. Se piensa también que en Sahagún hay algunas influencias del evemerismo, propio de las creencias de su época: Evémero era un filósofo y viajero griego que vivió entre los siglos III y IV a.C. y que en su obra Escrito Sagrado quiso demostrar que los llamados dioses habían sido en su tiempo seres humanos y que fueron considerados como dignos de culto por las generaciones posteriores (López Austin 2001).

Para López Austin, esta influencia es visible en Sahagún, quien afirmó la existencia humana de muchos de los dioses indígenas. Sahagún pudo haber tenido noticias de Evémero a través de san Agustín, quien lo menciona en el libro vi de La ciudad de Dios ${ }^{4}$, aunque en ninguna parte el religioso lo cita directamente: su influencia ha de buscarse en la cercanía de las ideas, sobre todo en el contexto de la defensa de la religión cristiana frente a los cultos paganos.

En el libro III, Sahagún ve a Quetzalcóatl como otro Hércules (recordemos que en el libro I relaciona a Hércules con Huitzilopochtli), pero no da mayores detalles sobre las características que justifican esta relación. Sobre esta temática resulta de gran interés el artículo de Javier Martínez Villarroya «Quetzalcoatl

\footnotetext{
${ }^{3}$ María José García (1989) señala que tampoco se encuentra tal identificación en el texto náhuatl.

${ }^{4}$ San Agustín decía: «¿Qué concepto tuvieron de Júpiter los que colocaron a su nodriza en el Capitolio? ¿No es cierto que confirmaron el pensamiento de Evémero, quien escribió no con mítica garrulería, sino con solicitud histórica, que todos esos dioses son hombres y seres mortales? Los que sentaron a la mesa de Júpiter a los dioses comilones y parásitos suyos, ¿qué pretendieron sino convertir lo sagrado en bufonesco?». Agustín, Civ., vi, 7, 251. Para Gilbert Highet: «Evémero explicaba todas las leyendas -divinas, humanas y semihumanas- diciendo que eran versiones ennoblecidas de las hazañas de guerreros y caudillos de carne y hueso que habían vivido mucho tiempo atrás, y que habían sido transformados en dioses por la admiración de sus tribus». Véase Highet 1996.
} 
y Heracles», donde se analizan en profundidad las analogías de estos mitos, señalando entre otras cosas:

Tanto Heracles como Quetzalcoatl son reyes expulsados de sus reinos, que en peregrinación se dirigen al País del Sol. Ambos reciben sacrificios de niños, civilizan pueblos y se debaten entre las dos vías, la del asceta y la del vividor. Su viaje a los infiernos se debe a que unen el cielo y la tierra, el espíritu y la materia, como fieles representantes de la realeza divina (Martínez 2005).

Efectivamente se pueden observar estas características en la obra del religioso: Sahagún relata que Quetzalcóatl se ve obligado a salir de la antigua ciudad de Tulla por engaño de unos nigrománticos. En su camino hacia la ciudad de Tlapalla, al igual que Hércules, fue viviendo varias aventuras como nos cuenta el propio religioso: «Hay otras cosas notables que hizo el Quetzalcóatl en muchos pueblos y dio todos los nombres a las sierras y montes y lugares» (Sahagún 1989).

A través de estas analogías existentes entre los dioses de los indios y las divinidades grecorromanas, Sahagún elabora un trabajo etnohistórico que aproxima a sus lectores a los antiguos dioses mexicanos y sobre todo a las creencias religiosas de estos pueblos, que han de ser conocidas para poder lograr la expansión de la fe cristiana.

\subsection{Fray Jerónimo de Mendieta (1525-1604): Historia ECLesiástica Indiana}

Fray Jerónimo de Mendieta fue también un religioso franciscano considerado uno de los últimos testigos de la edad dorada del siglo xvi. Como resultó común en su época, su máxima obra, Historia Eclesiástica Indiana, no llegó a imprimirse. La obra desapareció y solo se conoció su contenido parcial a través de la obra de fray Juan de Torquemada Monarquía indiana (1615). La Historia Eclesiástica de Mendieta se consideró perdida durante mucho tiempo hasta que el historiador y bibliógrafo español Pascual de Guayangos la encontró en la biblioteca del erudito y escritor Bartolomé José Gallardo. Por Guayangos la obra llegó al historiador mexicano Joaquín García Icazbalzeta, quien la publicó en 1874 (Valenzuela 2014). Su redescubrimiento a fines del siglo XIX resultó esencial para ampliar el conocimiento de los métodos misionales aplicados en el Nuevo Mundo.

Fray Jerónimo de Mendieta ingresó a la orden franciscana en 1545. En 1554 se trasladó a México para realizar labores de evangelización. Volvió a la península Ibérica en 1570, pero tres años después regresó a América de forma definitiva, tiempo en el que escribió la Historia Eclesiástica Indiana. En su obra, el religioso alaba las buenas condiciones de los nativos para recibir la palabra de Dios. Para Martínez Ferrer, Mendieta descubre en los naturales prehispánicos «valores religiosos auténticos, que conectan con lo mejor de la religiosidad y moral de los paganos clásicos como Aristóteles o Virgilio» (Martínez Ferrer 2008). Insiste en que originalmente los indígenas fueron monoteístas, tuvieron el conocimiento de un único y verdadero Dios, y que solo cayeron en el politeísmo como engaño del demonio. Asegurando este antecedente, los religiosos se convencían aún más de que los indígenas tenían todas las condiciones para adoptar sin problemas la religión cristiana. 
Pese a su marcado carácter milenarista que veía la proximidad del fin del mundo y la llegada de una nueva era, Mendieta no se mantiene ajeno al humanismo del siglo XVI, ya que los intereses misionales de los franciscanos lograron establecer una destacada conexión con el mundo clásico. En Sahagún, la América precolombina y la Antigüedad clásica funcionan como periodos análogos, esto significa que se buscan las similitudes entre la conversión de los indios del Nuevo Mundo llevada a cabo por estos evangelizadores con la conversión de los gentiles de la Antigüedad clásica (Phelan 1972).

En este breve análisis, utilizamos la edición de la Historia Eclesiástica Indiana de 1973, perteneciente a la Biblioteca de Autores Españoles (BAE). En la obra podemos constatar que, al igual que Sahagún, Mendieta trata de explicar la religión de los indios de la Nueva España recurriendo a ejemplos del mundo clásico y también a los escritos de Aristóteles y Virgilio. Luis Martínez Ferrer señala que las referencias a estos autores permiten interpretar con cierto realismo y «cientificidad» la religión prehispánica (Martínez Ferrer 2008), sobre todo cuando busca similitudes entre las creencias de los antiguos con los nativos del Nuevo Mundo:

Y así en lo primero conformaban con los gentiles antiguos, que a las ánimas de buenos y malos hacían moradores del infierno, como lo cuenta Virgilio en sus Eneidos, escribiendo la bajada de Eneas a aquel lugar (Mendieta 1973).

Mendieta continúa la comparación de las creencias de los nativos con el mundo cristiano, ya que señala que para ellos la medida de los castigos se aplica de acuerdo a la magnitud del pecado, y sobre este punto habría similitud entre los naturales de Indias, los antiguos griegos y los actuales cristianos.

Allí se refieren la diversidad de tormentos que vio Eneas, y por el consiguiente conforman con nosotros los cristianos que tenemos por fe lo que en diversas partes de la Escritura Sagrada se dice: que según la medida del pecado, será la manera de las llagas (Mendieta 1973).

En materia de los dioses, el que parece disgustar menos a Mendieta es Quetzalcóatl, quien ocupa un lugar principal en el conjunto de las creencias religiosas y que era reverenciado por tres cosas; primero, porque enseñó el oficio de la platería; segundo, por no admitir sacrificios de sangre; y tercero, porque vedaba y prohibía con eficacia la guerra, robos, muertes y otros daños. Posiblemente, se podría hacer más tolerable por el hecho de que a él no iban asociados los tan deplorables sacrificios humanos que tanto excitaron la imaginación de los religiosos y de los conquistadores en general (fig. 2).

En otro aspecto, reconoce que nahuas y otomíes tenían sus propias creencias sobre la vida y la muerte, contando que a los que morían de enfermedad «un perro bermejo los hacía pasar un río muy ancho, donde quedaban para siempre: que alude a la de la laguna Estigia, y al can Cerbero de nuestros antiguos gentiles» (Mendieta 1973).

Un uso similar de la Antigüedad se encuentra más adelante cuando relata que un sacerdote de los ídolos se vistió como el dios del vino. 


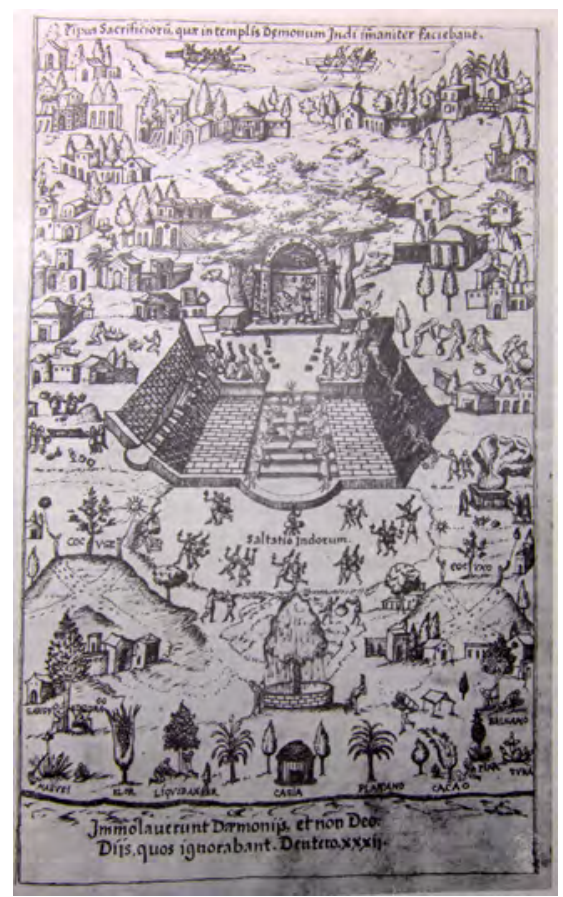

Figura 2. Representación de los sacrificios indígenas en Jerónimo de Mendieta, Historia Eclesiástica Indiana, edición de 1973, libro II, p. 50.

Quiso uno de ellos hacer demostración ante el pueblo, para que entendiese la gente que no había que temer al Dios de los cristianos ni a sus predicadores y para esto vistióse de las insignias de un dios que ellos tenían, llamado Ometochtli, que decían ser el dios del vino (como otro Baco), y salió al mercado mostrándose muy feroz y espantable (Mendieta 1973).

En la obra, Ometochtli es puesto en relación con Baco y aquel que se disfrazó del dios del vino murió debido al ataque de la gente del pueblo. Encontramos en la obra de Mendieta ejemplos concretos sobre la comparación de los dioses nativos con los de la Antigüedad grecorromana, logrando identificar en un autor de marcada influencia milenarista ${ }^{5}$ importantes valores de la tradición clásica. Por

5 Mendieta apostaba por mantener una Iglesia primitiva en las Indias, por lo que era necesaria la segregación de las comunidades indígenas como una condición para la creación de un reino milenario, como se ha señalado anteriormente. Por ello dedicó importante tiempo y energía en convencer a las autoridades de la necesidad de proteger a los indígenas (Valenzuela 2016). Los milenaristas creían que Cristo volvería a reinar sobre la tierra durante mil ańos, antes del último 
ello, se han de considerar ambas vertientes en los nuevos análisis que aborden la obra de este franciscano.

\subsection{JosÉ de Acosta (1540-1600): Historia NATURAL Y MORAL DE LAS INDIAS}

La Historia Natural y Moral de las Indias del jesuita José de Acosta, ha sido un referente para el estudio de la historia y de la antropología del Nuevo Mundo, convirtiéndose en un libro trascendente para el conocimiento de la naturaleza y la geografía, así como del pasado y las costumbres indígenas. Su obra constituyó todo un referente posterior en la elaboración de las historias naturales jesuitas realizadas por destacados intelectuales como Francisco Xavier Clavigero, Bernabé Cobo, Juan de Velasco o Juan Ignacio Molina (Valenzuela 2018).

José de Acosta, procedente de Medina del Campo, ingresó muy joven a la Compañía de Jesús. Realizó estudios en Alcalá de Henares, reconocido centro humanista español de la época. Se desempeñó como profesor en diversas residencias de la Compañía en España y en 1571 llegó a América para establecerse en el Virreinato del Perú, desde donde realizó diversos viajes con fines misioneros. En 1586 viajó hacia Nueva España, donde permaneció casi un año para luego regresar a España. En 1588 salía impreso en Salamanca su primer libro, De Procuranda Indorum Salute, precedido del De Natura Novi Orbis. De la traducción al castellano de este último surgirían los dos primeros libros para su Historia Natural y Moral de las Indias (1590), dedicada a la infanta Isabel Clara Eugenia, hija del rey Felipe II. En Roma, imprimió algunas obras en latín: De Christo Revelato libri Novem y De Temporibus Novissimus Libri Quatuor. En este sentido, Acosta fue más afortunado que Bernardino de Sahagún y Jerónimo de Mendieta porque pudo ver publicada su obra en vida y con una muy amplia difusión, ya que al año siguiente de su primera publicación se editó también en Barcelona, fue traducida en 1596 al italiano, en 1598 al holandés y francés, en 1601 al alemán y en 1604 al inglés (Marroquín 2019). La edición que utilizamos en este análisis corresponde a la de 2008, realizada por Fermín del Pino Díaz.

En la Historia Natural y Moral de las Indias, las principales alusiones a los dioses indígenas y su comparación con los dioses grecolatinos las encontramos en la parte correspondiente a la historia moral, que hace referencia a las tradiciones y costumbres de los nativos, específicamente en el libro v, donde explica en qué consistían los dioses adorados por los indígenas del Perú:

combate contra el mal, para comenzar así el Juicio Universal. Este pensamiento se extendió especialmente durante la Edad Media, pero también tuvo influencias posteriores, como lo demuestra la obra de Jerónimo de Mendieta o posteriormente, el jesuita chileno Manuel Lacunza con su obra La venida del Mesías en Gloria y Majestad (1790). El libro de Lacunza fue incluido en el índice de libros prohibidos por la Inquisición. 
También adoraban a la tierra, que llamaban Pachamama, al modo que los antiguos celebraban la diosa Tellus; y al mar, que llamaban Mamacocha, como los antiguos a la Tetis o al Neptuno (Acosta 2008).

Al comparar la religión de los pueblos de México con la de los indígenas del Perú, Acosta considera que la idolatría de los mexicanos fue más errada y perniciosa que la de los incas porque

la mayor parte de su adoración e idolatría se ocupaba en los ídolos y no en las mismas cosas naturales, aunque a los ídolos se les atribuía estos efectos naturales, como del llover y del ganado, de la guerra, de la generación, como los griegos y latinos pusieron también ídolos de Febo, y de Mercurio, y de Júpiter, y de Minerva, y de Marte, etc. (Acosta 2008).

Para Acosta la religión de los peruanos puede bien compararse con la romana, al relacionar un templo del Perú con el Panteón de los romanos, ya que se trataba de la casa y morada de todos los dioses, al encontrarse allí los dioses de todas las provincias, incluso de aquellos lugares conquistados:

Otro templo y adoratorio aún muy principal hubo en el Perú, que fue en la ciudad del Cuzco, donde es agora el monasterio de Santo Domingo, y en los sillares y piedras del edificio, que hoy día permanecen, se echa de ver que fuese cosa muy principal. Era este templo como el Panteón de los romanos, cuanto a ser casa y morada de todos los dioses. Porque en ella pusieron los reyes Ingas los dioses de todas las provincias y gentes que conquistaron, estando cada ídolo en su particular asiento y haciéndole culto y veneración los de su provincia con un gasto excesivo de cosas que se traían para su ministerio, y con esto les parecía que tenían seguras las provincias ganadas, con tener como rehenes sus dioses (Acosta 2008).

A lo largo del libro v se observa que el jesuita no se muestra en absoluto escandalizado con la idolatría de los indígenas, ya que también los antiguos griegos y romanos vivieron en la idolatría según la visión de la época. Sin embargo, hay algunos hechos que le causan gran admiración y que describe con lujo de detalles; ejemplo de ello es lo sucedido en una ceremonia en México, donde se le arrancó el corazón a un joven, estando de testigos varios españoles:

Habiendo abierto y sacado el corazón a un mancebo muy bien dispuesto, y echándole rodando por la escalera abajo como era su costumbre, cuando llegó abajo, dijo el mancebo a los Españoles en su lengua: Caballeros muerto me han (Acosta 2008).

Estos hechos que sorprenden tanto a los conquistadores españoles encuentran respuesta en el razonamiento de José de Acosta citando nuevamente a los clásicos:

Y no es cosa increíble, que aquel hablase habiéndole arrancado el corazón pues refiere Galeno haber sucedido algunas veces en sacrificios de animales, después de haberles sacado el corazón, y echándole en el altar, respirar los tales animales, y aun bramar reciamente, y huir por un rato (Acosta 2008). 

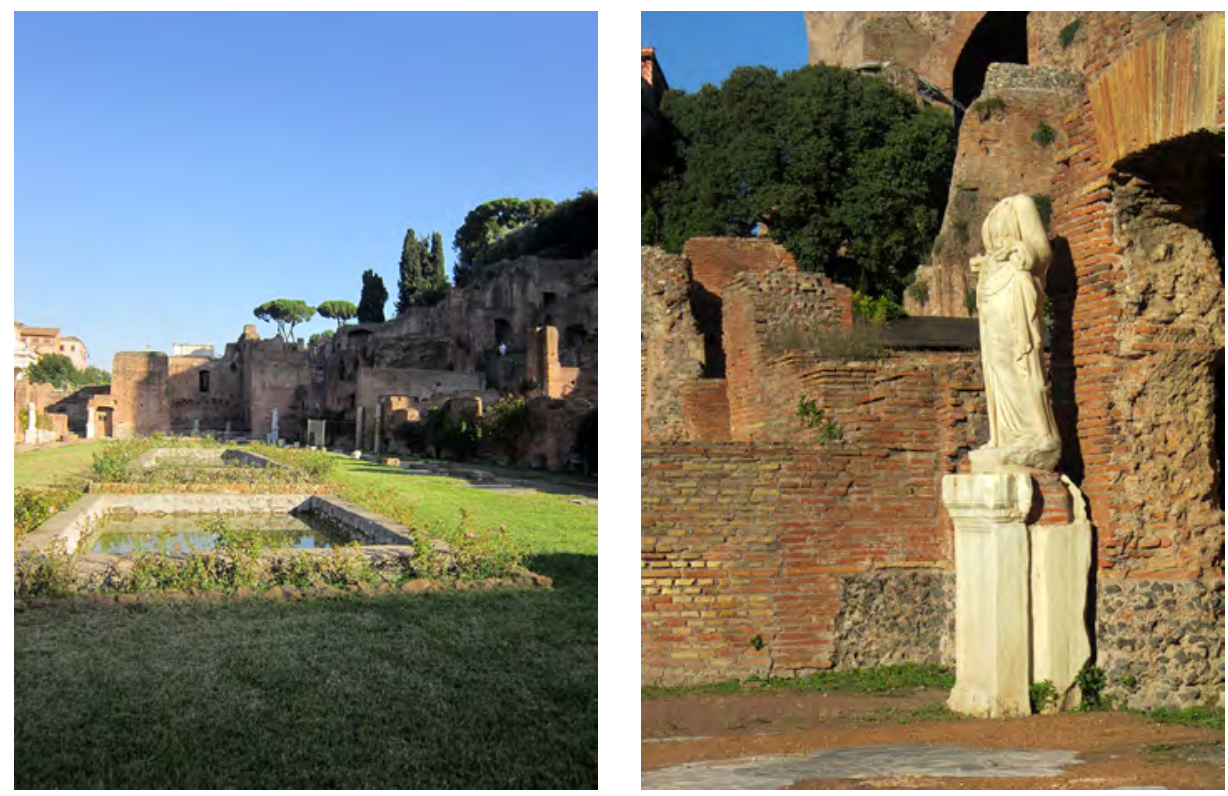

Figuras 3 y 4 . Los conquistadores y evangelizadores vieron un gran parecido entre las acllas del Imperio inca y las vestales de Roma. Imagen de la Casa de las Vestales. Roma. Fotografías de la autora.

Al igual que Sahagún, Acosta también habla de uno de los dioses principales de los mexicanos, Quetzalcóatl, refiriéndose a este como uno de los más venerados en Cholula en su condición de dios de las mercaderías. En este caso, Quetzalcóatl no es comparado con Hércules, sino con Plutón:

Era en figura de hombre, pero la cara de pájaro, con un pico colorado y sobre él una cresta y verrugas, con unas rengleras de dientes y la lengua de fuera. En la cabeza, una mitra de papel puntiaguda pintada; una hoz en la mano y muchos aderezos de oro en las piernas y otras mil invenciones de disparates, que todo aquello significaba y, en efecto, le adoraban porque hacía ricos a los que quería, como el otro dios Mamón, o el otro Plutón (Acosta 2008).

En el siguiente capítulo se refiere al monasterio de vírgenes de Acllaguaci, en el Perú, encontrando semejanza entre estas doncellas y el sacerdocio femenino en México con las vírgenes vestales de Roma referidas por los historiadores (figs. 3 y 4) (Acosta 2008) ${ }^{6}$.

${ }^{6}$ El autor no especifica a cuáles historiadores se refiere, siendo varios los que hacen referencia en sus textos a las sacerdotisas de Vesta, entre ellos Dión Casio, quien nos señala que a ellas se les 
Alguna semejanza tiene lo de estas doncellas, y más lo de las del Perú, con las vírgenes vestales de Roma, que refieren los historiadores, para que se entienda cómo el demonio ha tenido codicia de ser servido de gente que guarda limpieza, no porque a él le agrada la limpieza pues el de suyo espíritu inmundo, sino por quitar al sumo Dios, en el modo que puede esta gloria de servirse de integridad y limpieza (Acosta 2008).

Ciertamente, Acosta tenía referencia de la diosa Vesta, diosa romana del hogar, y de las vírgenes consagradas a su culto, por lo que no duda en comparar a las vírgenes de Acllaguaci con las antiguas vestales. Vemos entonces que Acosta intenta también comprender los atributos de los dioses y las características de la religión de los nativos a través del prisma de la Antigüedad clásica. Para realizar estas comparaciones, Acosta se vale de diversas fuentes, entre ellas resulta importante su propia experiencia personal, que incluía sus navegaciones transatlánticas, su trabajo como visitador, historiador y teólogo en el Perú y su viaje a la Nueva España. También se valió de la consulta a expertos en los temas que le interesaban, y entre estos expertos se encontraron con frecuencia los propios indios americanos (Marroquín 2019).

Acosta también trata en su libro la similitud de los ritos católicos y paganos, sobre todo en lo que él ve en la semejanza con la comunión, y a través de ello busca una amplia descripción sobre sus ceremonias. Se refiere también a la confesión y a los confesores y realiza comparaciones con los ritos del Japón, de los cuales parece estar correctamente informado a través de los miembros de la Compañía que se encuentran en Oriente. Busca asimismo la semejanza de los ritos de los indios con los cristianos y vuelve a insistir en que las idolatrías practicadas en Cuzco o en México son del mismo tipo que en su tiempo se dieron en Roma o en Jerusalén. Describe también las fiestas ordinarias y extraordinarias de los incas y los mexi-

encargó «que tuvieran el cuidado del fuego y del agua» y que "guardaban su virginidad durante su vida y, si no, las enterraban con piedras». Ver, D.C. Historia Romana, 182. También lo hace Suetonio, en su vida de Augusto, comentando que «aumentó el número de sacerdotes, su dignidad y hasta sus privilegios, especialmente los de las vestales. Habiendo fallecido una de éstas se trataba de reemplazarla, y como muchos ciudadanos solicitasen el favor de no someter a sus hijas a los riesgos del sorteo, dijo él que si alguna hija suya hubiese llegado a la edad requerida la hubiese ofrecido espontáneamente». Suet. Aug., 108. También aparecen referencias en la vida de Tiberio Nerón, quien tiene una entre sus antepasados: «Viese asimismo una Claudia, sacerdotisa de Vesta, montar en el carro de su hermano, que iba en triunfo a pesar del pueblo, y acompañarle de este modo hasta el Capitolio, con el objeto de que los tribunos nada pudieran contra él». Suet. Tib., 180. Encontramos también importante referencia en las Cartas de Plinio el Joven: «Estoy muy inquieto por la enfermedad de Fania. La contrajo mientras cuidaba a la vestal Junia, al principio por propia voluntad (pues Junia es pariente suya), luego también por orden de los pontífices. Pues las vírgenes vestales, cuando son obligadas por una grave enfermedad a abandonar el templo de Vesta, son confiadas al cuidado y protección de mujeres casadas». Plin. Ep., 19, 2. También encontramos información en san Agustín en varias partes de La ciudad de Dios, entre ellas citamos: «Pues los antiguos romanos enterraban vivas a las sacerdotisas de Vesta sorprendidas en relaciones ilícitas». Libro III, 5, 216-217, sobre este castigo también da noticia Plin. Ep., Iv, 11, 7. También nos dice san Agustín: «Vesta no es sino el fuego propio de los hogares, sin los cuales la ciudad no puede existir, y que suelen estar a su servicio unas vírgenes...». Libro IV, 10, 293. 
canos, donde es apreciable su labor etnográfica, lo que se contradice con la poca importancia que dice dar a estos temas, tal vez por guardar la debida cautela de no poner el mayor énfasis en materias que habían sido restringidas desde las Ordenanzas de Felipe II en 1577.

Los aspectos comparativos de la religión indígena con la grecorromana son solo uno de los elementos de la influencia clásica en su obra. La influencia clásica en la Historia Natural y Moral es mucho más relevante cuando se tocan aspectos referentes al mundo natural y físico de América. En ellos se identifican claramente las influencias de la Historia Natural de Plinio el Viejo, presentes en los capítulos dedicados a la minería y a la naturaleza, y sobre las que se han desarrollado extensas investigaciones (Salazar 2000, López Gregoris 2008, Pino Díaz 2008, Valenzuela 2017, Marroquín 2019), que también enfatizan la influencia intelectual de José de Acosta en los posteriores naturalistas europeos del siglo xviii, así como y la revalorización de su obra durante la época de la Ilustración.

\section{CONCLUSIONES}

La Antigüedad clásica está muy presente en la visión que los conquistadores y evangelizadores espańoles del siglo xvi proyectaron sobre el Nuevo Mundo considerando especialmente el contexto del Renacimiento europeo, que generó una revalorización de los clásicos grecolatinos a través de la difusión de sus obras y también de su gusto artístico. Uno de estos aspectos es el uso de la mitología clásica y en especial de los dioses y héroes grecorromanos, que funcionaron como un elemento comparativo para comprender las creencias religiosas de los nativos americanos y asimilarlos a sus dioses locales de acuerdo a la cercanía con sus respectivos atributos.

Esta comparación, llamada también «a efectos compensatorios» (Pino Díaz 1982), buscaba hacer más cercana la realidad remota y desconocida de un nuevo continente a un lector europeo culto (religiosos o laicos), familiarizado con la Antigüedad clásica. De esta manera, Huitzilopochtli o Quetzalcóatl podían ser definidos como «otro Hércules» o comparados con el dios Plutón. El lector de su tiempo conocía los atributos del héroe mitológico grecorromano; por tanto, podía comprender los atributos de los dioses mexicanos, lo mismo que Ometochtli, que es «otro Baco", haciendo referencia al dios del vino. Asimismo, vemos que Acosta explica en la parte correspondiente a su historia moral que a los ídolos del Perú se les atribuían diversos efectos, igual que se hiciera en la Antigüedad clásica con Mercurio, Júpiter o Minerva.

Por otra parte, a través del prisma de los clásicos, los evangelizadores buscaban demostrar que los indígenas reunían las condiciones necesarias para la conversión al cristianismo y que sus sociedades se parecían en mucho a las de la antigua y admirada civilización grecorromana, que volvía a cobrar vida con el Renacimiento en Europa. No obstante, las creencias de los nativos nunca son comparadas con la religión católica, considerada como la fe verdadera y, por tanto, incomparable y superior a cualquier otra religión. 
De alguna manera, la comparación con los clásicos también busca proporcionar elementos de comprensión a un conjunto de creencias que solía causar rechazo a los conquistadores, por actos como los sacrificios humanos o el politeísmo, pero que, gracias a los paralelos con la mitología clásica, se hacían más fáciles de comprender para el lector culto europeo, quien podría hacerse una imagen de estas culturas, pero siempre con la distorsión que significaría la aplicación de un filtro clásico tan distante cultural, temporal y geográficamente a los pueblos de las Américas. Estas comparaciones generalmente sirven a un fin: la evangelización en el Nuevo Mundo, propósito que está claramente reflejado en las obras de estos tres religiosos, y que es facilitado y legitimado en parte gracias a las comparaciones clásicas de sus escritos. Las obras de Sahagún, Mendieta y Acosta buscan informar de los propósitos misionales y también de las condiciones favorables que ofrecen estos pueblos, según la particular visión de cada uno de ellos, para la implementación de la fe católica.

Recibido: 18 de febrero de 2020; ACEptado: 30 de septiembre de 2020 


\section{BIBLIOGRAFÍA}

Acosta, J. (2008). Historia Natural y Moral de las Indias. 1590, edición crítica de Fermín del Pino Díaz. Madrid: CSIC.

Agustín. Santo, Obispo de Hipona (2007). La Ciudad de Dios, libros I-VII, introducción, traducción y notas de Rosa Marina Sáez. Madrid: Gredos.

Ballesteros, M. (1973). Vida y obra de Fray Bernardino de Sahagún. León: Institución Fray Bernardino de Sahagún.

Ballesteros, M. (1964). Códices Matritenses de la Historia General de las Cosas de la Nueva España de Fr. Bernardino de Sahagún. Madrid: Edición José Porrua Turanzas.

Brading, D. (1991). Orbe Indiano. De la monarquia católica a la República criolla, 1492-1867. Ciudad de México: Fondo de Cultura Económica.

Biersack, M. (2009). «Los Reyes Católicos y la tradición imperial romana». eHumanista, vol. 12, pp. 33-47.

Dion Casio (2004). Historia romana, libros I-XXXV (fragmentos), introducción, traducción y notas de Domingo Plácido Suárez. Madrid: Gredos.

Contreras, J., Ramos, G. y Rico, I. (1992). Diccionario de la Religión Romana. Madrid: Ediciones Clásicas.

García Jurado, F. (2016). Teoría de la tradición clásica. Conceptos, historia y métodos. Ciudad de México: Universidad Nacional Autónoma de México.

Greenblatt, S. (2011). El Giro. De cómo un manuscrito contribuyó a crear el mundo moderno. Barcelona: Crítica.

Highet, G. (1996). La Tradición Clásica, Influencias griegas y romanas en la literatura occidental. Ciudad de México: Fondo de Cultura Económica.

López Austin, A. (2001). "Fray Bernardino de Sahagún frente a los mitos indígenas». Ciencias, 60-61, pp. 6-14.

Martínez, J. (2005). «Quetzalcoatl y Heracles». EX NOVO, 1, Barcelona, 2005, pp. 43-66.

Martínez Ferrer, L. (2008). «Fray Jerónimo de Mendieta (1525-1604) y la religión mesoamericana prehispánica», en Sanz, S. y Maspero, G., editores. La natura della religione in contesto teologico, Roma: Edusc. pp. 183-205.

Martín-Esperanza, P. (2018). "Alejandro VI y las Antigüedades de Roma: coleccionismo, excavaciones y spolia». Revista Borja, Revista de L'IIEB, 6 (2017-2018), pp. 1-28.

Marroquín Arredondo, J. (2019). «La historia natural de José de Acosta y la física del globo de Alexander von Humboldt», en Marroquín, J. y Morales, A. Ciencia y traducción jesuitas en el septentrión novohispano. Nuevo Mundo Mundos Nuevos [Internet] [cited 25 abril 2020] Available from https://journals.openedition.org/nuevomundo/77934.

Mendieta, J. (1973). Historia Eclesiástica Indiana, 1604, estudio preliminar y edición de Francisco Solano y Pérez Lila. Madrid: BAE.

Phelan, John (1972). El Reino Milenario de los Franciscanos en el Nuevo Mundo, Universidad Nacional Autónoma de México: Ciudad de México D.F.

Pino Díaz, F. (1982). "Culturas clásicas y americanas en la obra del Padre Acosta», en Solano, F. y Pino Díaz, F. (eds.). América y la España del siglo XVI. Madrid: CSIC. pp. 327-363. 
Plinio el Viejo (1995). Historia Natural, libros I, II, introducción General de Guy Serbat. Madrid: Gredos.

Plinio el Viejo (1998). Historia Natural, tomo ir a, trasladada y anotada por el doctor Francisco Hernández. Ciudad de México: Visor/UNAM.

Plinio el Viejo (1998). Historia Natural, libros III-VI, traducción y notas de Antonio Fontán, Ignacio García Arribas, Encarnación del Barrio, María Luisa Arribas. Madrid: Gredos.

Plinio el Joven (2005). Cartas, introducción, traducción y notas de Julián González Fernández, Madrid: Gredos, 2005.

Reynolds, L. y Wilson, N. (1986). Copistas y filólogos. Madrid: Gredos.

Rodríguez, J.L. y Vicente Castro, F. (1986). Bernardino de Sahagún, primer antropólogo en Nueva España (siglo XVI). Salamanca: Ediciones Universidad de Salamanca.

Sahagún, B. (1989). Historia general de las cosas de la Nueva España, 1580, primera versión íntegra del texto castellano del manuscrito conocido como Códice Florentino, introducción, paleografía, glosario y notas de Alfredo López Austin y Josefina García Quintana. Madrid: Alianza Editorial.

Suetonio (1982). Los Doce Césares. Seguido de Gramáticos Ilustres, traducción del latín y notas por Jaime Arnal. Barcelona: Iberia.

TÁcito (1999). Vida de Julio Agrícola, Germania, Diálogo de los Oradores, edición de Beatriz Antón Martínez. Madrid: Gredos.

Valenzuela Matus, C. (2014). «Espiritualidad medieval y antigüedad clásica. La Historia Eclesiástica Indiana de Fray Jerónimo de Mendieta». Historias del Orbis Terrarum, 13, pp. 155-175.

Valenzuela Matus, C. (2016). Grecia y Roma en el Nuevo Mundo. La recepción de la antigüedad clásica en cronistas y evangelizadores del siglo XVI americano. Barcelona: Editorial Rubeo.

Valenzuela Matus, C. (2018). Clásicos y naturalistas jesuitas. Los antiguos en la interpretación de la naturaleza americana. Siglos XVII-XVIII. Barcelona: Editorial Rubeo. 



\title{
CELIA LEYTON, SU PINTURA INDIGENISTA, RETRATO DEL PATRIMONIO CULTURAL DEL PUEBLO MAPUCHE
}

\author{
Lorena Villegas*, Renzo Vaccaro** y Alex Mellado*** \\ Universidad Católica de Temuco
}

\begin{abstract}
RESUMEN
Esta investigación ofrece una mirada académica sobre aspectos destacables de la vida y obra de la artista Celia Leyton Vidal (Santiago de Chile, 1895-1975), quien desarrolló gran parte de su trabajo pictórico en la región de La Araucanía, situada en el sur de Chile. Tuvo un alto perfil en su labor como docente, artista investigadora y promotora de los valores culturales del pueblo mapuche. Realizó un profundo trabajo de campo que se evidencia en anotaciones, bosquejos, descripciones e interpretaciones de sus experiencias investigativas, las que le permitieron, además de crear un gran cuerpo de obra, producir textos (catálogos y una autobiografía) con el objeto de acercar a las personas los valores y virtudes de la cosmovisión mapuche, cultura y etnia que consideraba en grave riesgo de desaparecer. Una primera revisión biográfica ha develado el contexto de su formación académica, su condición de género y los referentes que orientaron sus perspectivas de representación visual y sus valores ético-sociales. Por último, este trabajo investigativo conforma un análisis formal y simbólico de una de sus creaciones pictóricas, específicamente un autorretrato, en donde se relevan algunas claves que permiten configurar el valor de su proyecto artístico y cultural. Palabras Clave: Celia Leyton, pintura indigenista, retrato, patrimonio cultural.
\end{abstract}

\section{CELIA LEYTON, HER INDIGENOUS PAINTING, PORTRAIT OF THE MAPUCHE'S CULTURAL HERITAGE}

\section{Abstract}

This research explores key aspects of the life and work of the Chilean artist Celia Leyton Vidal (Santiago de Chile, 1895-1975). Celia Leyton's research and painting work was mainly developed in La Araucanía, the southern Chilean region where she spent most of her adult life. As a prominent middle school teacher, art researcher and painter, Leyton made a significant contribution to the academic art domain, and was devoted to the promotion and dissemination of the Mapuche culture and values. Her prolific field work includes annotations, sketches, descriptions and analysis of her research experiences, all of which led to the creation of numerous paintings and documents, including catalogues and an autobiography. Fearing it was endangered in modern times, the artist devotedly dedicated her entire life and work to disseminate Mapuche culture, virtues and worldview. A first biographic review provided a general understanding about the painter's life, her academic background, gender-related struggles, as well as the influential references that contributed to shape her social and ethical profile, and her visual representations and symbolism. Finally, we discuss a formal and symbolic analysis of a self-portrait, considered as one of her most important art works, and which reveals the true value of her artistic and cultural project.

KEYwORDs: Celia Leyton, indigenous painting, portrait, cultural heritage. 


\section{INTRODUCCIÓN ${ }^{1}$}

Este artículo presenta una mirada general sobre aspectos considerados relevantes para poner en valor la vida y obra de la artista chilena Celia Leyton Vidal. Esta mirada general de su obra establece algunas bases que posibilitan una comprensión más amplia de sus ideas y motivaciones en el campo artístico desarrolladas en la primera mitad del siglo xx en Chile.

Celia Leyton Vidal (Santiago de Chile, 1895-1975) fue una artista visual que desarrolló gran parte de su trabajo en la región de La Araucanía, en el sur de Chile. Tuvo un rol activo en la plástica nacional; sin embargo, su vida y obra han sido poco investigadas, generándose un silencio historiográfico de su legado. Uno de los factores que pudieron haber influido en su bajo reconocimiento es la lejanía geográfica en la cual ella desarrollaba su trabajo, situado en la ciudad de Temuco. En este contexto era muy complejo lograr notoriedad artística estando lejos de la escena plástica que se desarrollaba en Santiago. Otros de los factores que pudieron haber contribuido en su bajo reconocimiento son los temas en los cuales ella centró su obra, focalizados en representar costumbres y personajes de la cultura mapuche, motivo pictórico que estaba distante de las temáticas que se desarrollaban en la plástica nacional de esa época. Momento también de absoluto dominio de «lo masculino" en el circuito de las artes nacionales e internacionales, tanto en la producción de obra como de crítica y de formación académica.

Este artículo está centrado en tres ejes. El primero corresponde a una revisión biográfica de Celia Leyton que permite establecer su contexto de formación académica, su condición de género y los referentes que determinaron sus perspectivas de representación visual. El segundo eje aborda los alcances etnográficos de su trabajo, los que develan sus referencias políticas y éticas con respecto a la sociedad e historia chilena de esa época. Finalmente, el tercer y último eje analiza su cuerpo de obra en un contexto social, político y cultural clave del arte chileno de mediados del siglo xx donde se sitúa su producción artística.

Gran parte de su obra se encuentra en importantes colecciones privadas en Chile y en el extranjero, como también expuesta en algunas reparticiones públicas, como embajadas y municipalidades ${ }^{2}$. Realizó una extensa labor docente, escribiendo

* Universidad Católica de Temuco.E-mail: lvillegas@uct.cl.

** Universidad Católica de Temuco.E-mail: rvaccaro@uct.cl.

*** Universidad Católica de Temuco.E-mail: amelladol@uct.cl.

${ }^{1}$ Nota aclaratoria: Los términos propios de la lengua mapuche mapuzungun que aparecen aquí registrados están escritos según consta en las fuentes originales. Al ser estas variadas, se entrecruzan las versiones escritas por la misma Celia Leyton con las de la prensa local y otras fuentes utilizadas por el equipo de investigadores. Por ello, una misma palabra propia del mapudungun, puede aparecer aquí escrita de distinto modo, dependiendo de la fuente citada específicamente.

${ }^{2}$ La obra pictórica de Celia Leyton está bastante dispersa, debido a que sus obras han sido donadas, vendidas y puestas en comodato. En primera instancia se han identificado dos colecciones privadas con pinturas y bocetos de la artista. Otras obras se encuentran en el Regimiento de Montaña n. 8 Tucapel de Temuco, Liceo Gabriela Mistral de Temuco, Pinacoteca de la Universidad de 
diversos artículos y dos libros (Araucanía, rostro de una raza altiva y Rupandungú). En términos generales, su prolífica labor artística fue coronada con la fundación de la Academia de Bellas Artes de Temuco. Otros hitos importantes fueron los viajes y exposiciones fuera del país; entre estas últimas se destacan las realizadas en las ciudades de Madrid y Cuenca, en España. También su nombre ha sido reconocido en diversos ámbitos culturales de Chile, siendo uno de los más relevantes su nominación como «Mujer Bicentenario» ${ }^{3}$.

\section{ACERCA DE SU BIOGRAFÍA}

En un principio, su formación artística la realizó en la Escuela Técnica Femenina en Santiago de Chile, donde tuvo como profesores de dibujo y pintura a Nicanor González Méndez y Pedro Rezka Moreau ${ }^{4}$. Posteriormente, ingresó a la Escuela de Bellas Artes en Santiago, donde tuvo como maestros de pintura y dibujo a Ricardo Richon Brunet ${ }^{5}$, Juan Francisco González ${ }^{6}$ y Alberto Valenzuela Llanos . Como ella misma relata

Bueno, llegué por fin al anhelado aprendizaje de la pintura, no a Bellas Artes, sino a la escuela Técnica Femenina, donde el profesor de dibujo y de pintura era

Concepción, Museo Histórico Gabriel González Videla y en el Museo Regional de La Araucanía, perteneciente al Servicio Nacional del Patrimonio Cultural, entre las que se tiene registro.

${ }^{3}$ La denominación a Mujeres Bicentenarias tenía como objetivo destacar el aporte de mujeres en distintos ámbitos del quehacer nacional en pos de la construcción de Chile del Bicentenario y que no fueron reconocidas en la historia reciente del país. Fuente: http://www.bicentenarias.cl/ms celia_leyton.htm.

${ }^{4}$ Pedro Rezska Moreau (1872-1960). Pintor chileno. Fue alumno de Pedro Lira, Juan Francisco González y Cosme San Martín. Con una importante carrera desarrollada en Francia, retorna a Chile en 1914, donde se dedicó por completo a la docencia. Fundador de la Sociedad Nacional de Bellas Artes en 1918. En 1947 obtuvo el Premio Nacional de Arte. Fuente: https:/www.artistasvisualeschilenos.cl/658/w3-article-39905.html.

5 Ricardo Richon Brunet (París 1866-Santiago de Chile 1946). Artista visual francés, de gran relevancia en el medio europeo de la época, recibió premiaciones y reconocimientos en Francia, EE. UU., España y Rusia. Fue profesor de pintura en la Escuela de Bellas Artes de Chile, llegando a ser su subdirector. Recibió importantes encargos del Estado de Chile, como, por ejemplo, su nombramiento como secretario general de la Exposición Internacional realizada en el Palacio de Bellas Artes, en el contexto de la celebración del Centenario de la Independencia de Chile. Fuente: http:// www.artistasvisualeschilenos.cl/658/w3-article-40028.html.

${ }^{6}$ Juan Francisco González Escobar (1853-1933). Pintor chileno. Fue alumno de Alessandro Cicarelli y Pedro Lira. Profesor por más de 30 años de las cátedras de Croquis y Dibujo al Natural en la Escuela de Bellas Artes. Es reconocido como uno de los pintores más importantes en la historia del arte chileno. Fuente: https://www.artistasvisualeschilenos.cl/658/w3-article-78055.html.

7 Alberto Valenzuela Llanos (1869-1925). Pintor chileno. Fue alumno de Cosme San Martín, Pedro Lira y Juan Mochi. Becado cuatro veces para estudiar pintura en Francia, logró la cátedra de Pintura en la Escuela de Bellas Artes en 1911. Junto con recibir innumerables premios y distinciones, obtuvo la Cruz de Caballero de la Legión de Honor, otorgada por el Gobierno francés. Fuente: https://www.artistasvisualeschilenos.cl/658/w3-article-40032.html. 
don Nicanor González Méndez, artista de renombre; establecimiento donde no habían jóvenes.

Dos o tres ańos transcurrieron dibujando solamente -era un gran dibujante González Méndez-, pero yo ardía en deseos de pintar y por ello me resultaba monótono el copiar y pintar los modelitos de yeso (Leyton 1968).

En los inicios de su carrera, la ansiedad por comenzar a pintar era inmensa, inquietud que fue de algún modo aplacada por las formas de enseñanza de las artes de la época. Estas clases consistían principalmente en la copia sistemática de modelos de yeso. Esta modalidad de aprendizaje académico le produjo en cierto modo una frustración al no poder expresarse libremente en sus primeras creaciones. Posteriormente ingresó un nuevo profesor de dibujo, Pedro Reszka, quien le permitió tener una mirada distinta acerca del arte.

Un nuevo profesor de dibujo para los cursos de moda, don Pedro Reszka. Llegué hasta él pues había visto reproducciones magníficas de sus pinturas y también había leído algo de su interesante personalidad.

Con la caballerosidad que le distinguía, inmediatamente me acompañó a ver mi estudio que en esta ocasión era un grupo de diferentes frutas en una tela de $70 \times$ $50 \mathrm{~cm}$. El señor Reszka se sentó frente al cuadro y a la vez que daba explicaciones daba manotazos en el cuadro y toda la pintura de los tubos se le hacía poca para desparramarla para acá y para allá.

Frenética reprobación de mis compañeras por haber deteriorado el lindo cuadro y felicidad completa para mí, pues entonces empecé a deslumbrar lo que era el arte (Leyton 1968).

El trabajo que Celia Leyton realizó en ese entonces fortaleció su formación, ejecutando varios estudios que le permitieron visualizar sus habilidades artísticas y convencerse a sí misma de que debía ingresar a la Escuela de Bellas Artes, lo que se hizo efectivo en el año 1908.

Por fin llegué a la Escuela de Bellas Artes gracias a la intervención ante papá de unos primos sumamente católicos. Cumplida mi gran ambición.

En primer año, estudios de estatuas con el gentilísimo francés don Ricardo Richon Brunet $[\ldots]$

Dos años transcurrieron antes de llegar a la clase de don Juan Francisco González, a quien adoraba desde lejos; pero una vez ante él le tuve terror. [...] en el curso de croquis donde en un minuto se debía realizar por lo menos cinco croquis grandes ¡que decir!, este maestro era de un dinamismo asombroso (Leyton 1968).

Al cabo de unos años de rígida formación plástica, decidió abandonar la Escuela de Bellas Artes para dedicarse a la docencia en la educación primaria. Su primer trabajo en este ámbito estuvo en el Liceo de Niñas de Concepción, ciudad ubicada a $270 \mathrm{~km}$ al norte de Temuco. Luego de un par de años se trasladó a trabajar en el Liceo de Niñas de Temuco, donde se desempeñó desde el año 1931 al 1956, desarrollando en casi 25 ańos gran parte de su carrera como artista visual y profesora de arte. 
En términos generales, la mirada que Celia Leyton tuvo sobre el arte y la cultura está determinada en algunos aspectos por su propia formación académica en la pintura y el dibujo, así como también por su acervo cultural, influenciado por los discursos historicistas y socioculturales imperantes en la época. Sin embargo, su trabajo deja develar otros rasgos que posibilitan su situación como una artista representativa de una época y contexto en la historia del arte chileno, desarrollado en este caso en los márgenes de la oficialidad y el centralismo metropolitano. Ello se puede deducir del radio de acción restringido a lo local que marcó su trayectoria artística como docente y como pintora, que determinó su interés exploratorio e intercultural en una región aún fuertemente marcada por "La Frontera»" situada en la periferia de la influencia capitalina. Ello la mantuvo fuera de los circuitos santiaguinos, a pesar de haber obtenido varios reconocimientos y premiaciones en los concursos oficiales?.

\section{EN TORNO A SU PINTURA INDIGENISTA}

Si bien Celia Leyton se perfila como una de las principales representantes del arte indigenista en Chile, para comprender cómo ella desarrolló y proyectó su obra artística, es necesario visualizar el contexto latinoamericano y cómo esas ideas permearon de distinto modo su propia obra. El movimiento indigenista se vio influenciado por las ideas de reivindicación de los derechos indígenas que nacen de modo posterior a la Revolución Mexicana iniciada en 1910. Estas ideas impactaron progresivamente los ámbitos culturales, intelectuales y artísticos de gran parte de América Latina, contexto del cual Chile no estuvo ajeno. Desde esta perspectiva, el escenario social y político entre 1920 y 1930 influye con más o menos fuerza en el plano de las ideas estéticas, lo que activa la generación de varios movimientos artísticos que tuvieron asidero en las demandas y planteamientos sociales, reforzando la idea de la urgencia de una búsqueda o redescubrimiento de una identidad estética americanista. Uno de los movimientos más reconocidos de esta corriente indigenista es el muralismo mexicano, donde a través de su manifiesto, David Alfaro

${ }^{8}$ El concepto de «La Frontera» se gesta en Chile durante la denominada Guerra de Arauco, a partir de la segunda mitad del siglo xvir. La Frontera se sitúa en el sur de Chile, zona que sufre una serie de transformaciones que la convirtieron en un espacio de interacción, roces, conquista, guerra, ocupación e intercambios comerciales y culturales entre indígenas y espańoles. Este territorio se convirtió en un espacio de convivencia entre distintos actores, que por una parte representaban los intereses de la Corona y por otro los intereses de las distintas comunidades indígenas mapuches que ahí estaban establecidas (Ferrando 2012).

9 Entre sus principales premiaciones se pueden destacar la Medalla de Oro en la Escuela de Bellas Artes (1922), Medalla de Oro en la exposición de Pinturas de Concepción (1925), primer premio en la semana Penquista (1927), primer premio Exposición de Concepción (1929), Tercera Medalla en el Salón Nacional de Bellas Artes (1941), Medalla de Bronce en Salón Nacional. Homenaje a Maestros de Virgilio Arias Cruz y Enrique Swinburnkirk (1942), Medalla de Oro Municipalidad de Temuco (1948), Medalla de Plata Municipalidad de Temuco (1948) (Diario Austral 1950). 
Siqueiros da cuenta de esta lucha por la reivindicación de los derechos de los pueblos indígenas, utilizando como un medio y estrategia de representación la pintura mural para promover las ideas de educación, organización y cultura de masas. Sin embargo, en Chile este medio de difusión visual y político no tomó la fuerza que en otros países del continente.

... primero David Alfaro Siqueiros y Xavier Guerrero, en los murales de la Escuela México de Chillán y, luego Jorge González Camera, en Concepción generan argumentos y entusiasmos frente a una expresión artística hasta ese momento de presencia bastante menguada en el país. La posibilidad de dar una connotación de masividad a un texto estético, imbricado las más de las veces con un discurso social, permite un escalamiento no poco significativo de la pintura mural en el país, ello especialmente en la década de los años cuarenta al sesenta. Con todo, el muralismo en el país tiene una presencia puntual y muy acotada en el panorama de las artes visuales. Quizá haya faltado aquí la fuerza de la sangre, para transformar a esta interesante expresión artística en un fenómeno más trascendente en nuestro discurso estético (Zamorano y Cortés 2007).

Es en este contexto en el que en el año 1952, el Supremo Gobierno de Chile le solicitó a Celia Leyton la realización de un mural emplazado en dependencias del ex Liceo de Niñas de Temuco, actualmente Liceo Gabriela Mistral. Este encargo fue un reconocimiento a la labor creativa de la artista, cuyo tema central es el homenaje al primer profesor mapuche, Manuel Neculmán. Este educador, hijo de un longko ${ }^{10}$ de una comunidad indígena del sector de Boroa, localidad cercana a Temuco, representa el sentido y relevancia histórica que Celia Leyton le atribuye a la reeducación cultural y social de los hijos de los líderes mapuches (Foerster \& Montecino 1988).

El mural del edificio de Correos y Telégrafos de Chile ubicado en Temuco, actualmente oficina de Correos de Chile, es el segundo encargo en este formato que la artista lega a la comunidad local. La composición visual describe una escena del mundo mapuche: el huerkén (mensajero) le entrega un mensaje al «jefe de paz» Üllmen, el cual está registrado en una larga cuerda anudada (quipu). La misma Celia Leyton al referirse al contenido de este mural utilizó el término pron para describir este sistema de comunicación a larga distancia, cuyo instrumento es la cuerda anudada. Junto con la escena propiamente tal, están representados a modo descriptivo algunos objetos de alto valor cosmogónico, como el kultrun ${ }^{11}$, lanzas, piedras talladas, rewe $e^{12}$, entre otras. Este mural, de 2,80 × 5,75 metros, se encuentra en el

${ }^{10}$ Longko o cacique es el jefe o la autoridad de la comunidad mapuche. Está a cargo de los aspectos políticos, administrativos y religiosos de esta misma.

${ }_{11}$ Instrumento de percusión consistente en una vasija de madera cubierta de cuero (chivo o caballo). Tiene diversas funciones sociales; la más relevante es servir a la machi en sus ceremonias. También tiene un carácter simbólico y representativo (Hernández et al. 2002).

12 Tronco descortezado de árbol, labrado con peldańos (laurel, maqui, canelo), enterrado frente a la puerta de la ruka de la machi, de la cual es instrumento y símbolo. En algunos lugares y 
frontis superior de la sala principal del edificio, a una altura considerable y con una perspectiva de apreciación privilegiada, hasta el día de hoy (El Diario Austral 1962).

Celia Leyton centró su obra en la promoción de las costumbres y tradiciones del pueblo mapuche, a través de la cual realizó un riguroso ejercicio etnográfico creando retratos, escenas costumbristas y rituales que dan cuenta de aspectos cotidianos y de la cosmovisión de este pueblo. Este trabajo lo llevó a cabo mediante su constante contacto con personajes de diversas comunidades indígenas rurales aledañas a Temuco y otras comunas de la región, a las cuales ella viajaba para bocetear y pintar in situ escenas que los lugareños le permitieran plasmar. Este trabajo lo realizó por muchos años, ganándose la confianza de las comunidades indígenas y así poder ser testigo presencial de importantes ceremonias y rituales propios de la cosmovisión mapuche, que logró recrear en algunas de sus telas.

Es Celia Leyton un Diego de Rivera chileno. No porque lo haya imitado, ni porque pretenda realizar lo autóctono en la misma forma que el gran mexicano. No. La semejanza está en la ardorosa intención de entregarnos el mensaje del espíritu autóctono y los valores de una cultura enraizada, quierámoslo o no, en las entrańas de nuestro vivir actual.

La clase culta de todos los países latinoamericanos ha exaltado su ascendencia europea, española sobre todo. Y arroja una desdeńosa mirada a los abuelos autóctonos. La atención y aprecio que se dedica a Diego Rivera son resultados indirectos de las críticas mundiales que ya lo han consagrado como un valor eminente y sin par en las artes pictóricas americanas. Temo que pasen años antes que se le prodigue una migaja de gloria a esta mujer que hace de la humilde vida de las gentes araucanas el leitmotiv de su producción artística. A la vez, estoy cierta de que el futuro la elevará a un sitio de honra ejemplar y única (Labarca en Leyton 1968).

Su producción ha incorporado distintos lenguajes pictóricos, en los cuales utilizó diferentes soportes y formatos, como la pintura de caballete y la pintura mural. En un primer período de su formación, se abocó a los estudios tanto de obras maestras como de bodegones y paisajes naturales, estrategia que era muy utilizada en la academia. Esos ejercicios y obras los realizó en acuarela, pastel, óleo y la compleja técnica del fresco, con la que pintó los murales. Posteriormente, se centró en realizar escenas costumbristas y retratos de la cultura mapuche. Son variadas las fuentes que dan cuenta de la importancia que para ella tuvo este tipo de representación, principalmente en sus escritos autobiográficos, así como en la prensa local de la época.

Esa es la verdad, Celia Leyton lleva largos ańos batallando en el ambiente temuquense y regional para imponer su pintura, pero se encuentra con el desdén de mucha gente que no quiere nada con temas indios. El desprecio por el aborigen suele llegar hasta más allá de lo comprensible, hasta incluso odiar las expresiones artísticas que giran en torno a lo vernáculo. De la siempre activa virulencia de este

ocasiones es también una especie de pabellón o símbolo representativo de una determinada comunidad (Hernández et al. 2002). 
complejo, Celia Leyton recibe su cuota de sinsabores. Pero se sobrepone y sigue sin merma realizando su obra. No ha trepidado en sacrificios para cumplir su propósito, ha editado dos libros con la relación pictórica y literaria de la vivencia aborigen y ambos le han dejado pérdidas económicas (Leyton 1968).

Fueron muchos los sacrificios económicos y de vida que realizó la artista para llevar a cabo lo que ella determinó como «su labor». Así lo expresó Juan Francisco González (hijo), quien utilizaba el seudónimo de Huelen, reconocido crítico de arte en diversos medios escritos de la época.

Su pintura es la misma, la de su personalidad, pero ahora más luminosa y firme, con mayor sentido de la composición y de esa amplitud de temas que acusa un temperamento incansable, pleno de ansia de pintar, y de pintar para satisfacer esa sed inagotable que sigue y persigue al artista de verdad, cabezas admirables, flores luminosas, y más que todo el tema de su pasión, el indio en su fisonomía austera y grave y en sus costumbres y escenas típicas nos rodean en su taller (Huelen 1956).

\section{INSPIRACIÓN INDIGENISTA EN CELIA LEYTON}

Cuando nace Celia Leyton, en 1895, apenas acababa de concluir en el sur de Chile la llamada "Pacificación de la Araucanía», que consistió en términos generales en el desarrollo y culminación de un proceso político y jurídico empeñado en la reubicación de las comunidades indígenas, despojándolas consiguientemente de la mayoría de sus territorios. Tal como lo analiza Vargas en el artículo «Los aportes de Claude Joseph sobre el mundo mapuche: Cultura material y fotografía del Museo Histórico Nacional ${ }^{13}$, de aproximadamente cinco millones de hectáreas que poseían originalmente las comunidades mapuche, hacia el año 1883 les quedaban no más allá de 500000 (Vargas 2019).

Fue la artista una testigo de primera línea de este proceso que significó la desintegración de la vida mapuche, la pérdida de sus derechos, el robo y la usurpación de sus territorios, su consiguiente empobrecimiento, hambrunas y epidemias.

El panorama no era muy auspicioso para este pueblo. Tal como indica también Vargas (2019), existía un claro consenso entre las voces más expertas en el tema de la cultura mapuche en cuanto a que su destino era prácticamente una condena a la desaparición. En términos generales, una cultura empobrecida que termina siendo absorbida por la cultura dominante; en este caso, la chilena. El autor men-

13 «[...] El texto problematiza ambas dimensiones a partir tanto del término "cultura material" como de los estudios etnográficos del autor, recurriendo para ello a fotografías, textos y dibujos originales de su autoría depositados en el Museo Histórico Nacional. Se sostiene que Joseph aportó a la conformación de un campo de estudio del arte mapuche que contribuye a dar cuenta de la heterogeneidad cultural de este pueblo. Asimismo, se plantea que su producción fotográfica fue relevante para la instauración de ciertos imaginarios y que sus investigaciones colaboraron a la revitalización de la mencionada cultura» (Vargas 2019). 
ciona a importantes investigadores de esa época como Félix de Augusta (1910), quien entrega un claro diagnóstico: «La raza araucana pasa hoy por un período de transformación. Lo que nuestra obra refiere acerca de sus costumbres y supersticiones, dentro de poco ya no corresponderá a la realidad, ni se guardará memoria de ello» (p. vi) (De Augusta en Vargas 2019). No es de extrañar que los empeños de Celia Leyton respecto a una ética del arte consistieran en "rescatar» $\mathrm{y}$ «salvar del olvido» a los valores de la cultura ancestral.

Celia Leyton fijó su horizonte productivo en la urgencia de la valoración de lo mapuche, a través de la ejecución de paisajes y retratos de distintos personajes, algunos de alto rango social, como machis ${ }^{14}$, longkos o comerciantes, como también profesores y gente a veces anónima, que poblaron el imaginario de la artista. Existe numerosa documentación que permite observar el perfil de Celia Leyton como productora de imagen visual, pero también como investigadora en terreno, prácticas que hoy podríamos identificar como etnográficas. La búsqueda de la artista en su trabajo de ningún modo describe de forma literal los usos y costumbres mapuche, sino que definitivamente intenta escudrińar en los aspectos psicológicos y/o espirituales que «iluminan» la cultura.

Diecisiete años que vivo en Temuco. Temuco diríase es el centro de esta raza que otrora fuera fuerte y valerosa y que aun conserva casi intactas sus virtudes. Siempre me sedujo el típico y vistoso atavío de las mujeres araucanas y medité largamente sobre las costumbres del pueblo que nos sirvió de piedra angular para la formación de la propia raza. Sin embargo, no pinté inmediatamente. Primero investigué y pronto me convencí de que la enseñanza recibida por mí respecto a los mapuches era falsa en gran parte. Se ha mentido mucho acerca de los indios. Lo puedo decir con entereza. Se ha especulado con su flojera. No hay tal. La araucana es una raza que sufre resignadamente su suerte, pero que trabaja duramente. El hambre no le hace doblegar la cabeza. Su gente físicamente es magnífica, recia y fuerte. Muchos son los que piensan superficialmente que los mapuches son feos, flojos y borrachos y que deben desaparecer, sin darse el trabajo de pensar que sería más humanos crearles ambiciones de comodidades y de cultura y tratar de inculcarles confianza para que ingresen a la ciudadanía del país con iguales derechos que el «huinca» (El Diario Austral 1950a).

Este contexto de invisibilización y desprecio por las culturas indígenas por parte de la sociedad chilena de esa época complejizó enormemente la función que para ella tenía el arte. Su temprana formación académica en Santiago le permitió conocer los fundamentos del género del retrato en la tradición renacentista y moderna de la pintura. Sin embargo, fue evidente su rebeldía constante frente a las imposiciones del patriarcal mundo del arte y la cultura que ella debió enfrentar.

${ }^{14}$ Persona elegida por un espíritu superior para asumir el papel de médico tanto en lo físico como en lo psíquico y social. En algunos sectores es también oficiante principal en el ngillatun (Hernández et al. 2002). 
«Era de rigor agudizar mis pésimas condiciones de sociabilidad; debía ocultar mi cansancio, a veces mi descontento; sólo así podía obtener confidencias, relatos que encuentro en mis borradores...» (Leyton 1968). De este modo, Celia Leyton grafica su enorme empeño en conocer las prácticas culturales, creencias, cosmovisión, psicología y usos del pueblo mapuche, que luego decantaron en su producción

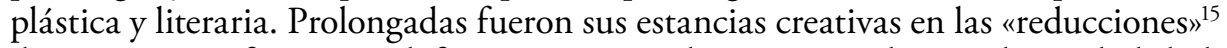
de Quepe, Pitrufquén, Carilafquén, Lautaro, Isla Huapi, Huilio, Maihue, Chol chol, Budi, Carahue, entre otras localidades de la región de La Araucanía.

Su paso por las ferias, exposiciones en hoteles y otras instancias de difusión de su obra estuvo cargado de sinsabores, menosprecio y omisiones que, sin embargo, no debilitaron su intención férrea de impulsar su carrera artística con un fin particular, humano y ético. Su trabajo fue postergado y negado en los estratos altos de la sociedad temuquense. En ciertos momentos, ya vencida por el cansancio de la incomprensión y falta de empatía del «circuito intelectual del arte» por su proyecto artístico, planeó abandonar la enseñanza primaria, suspender algunas de sus relaciones familiares directas, abandonar sus comodidades y sumergirse en la investigación en terreno, para así proyectar su visión del arte y la cultura mapuche, aspectos que de a poco se van amalgamando en un concepto de trabajo único y particular en ella. En este sentido, la artista no acostumbraba a deshacerse de sus bocetos, pues estos guardan la vibración esencial de los lugares y las personas.

Mujer de pocas palabras, según ella misma con pocas habilidades comunicativas, extremadamente tenaz, decidida, valiente a toda prueba, rebelde. De profunda vocación intercultural, amor por la divulgación y la docencia, aunque con profundos conflictos con los contenidos y metodologías establecidos en los programas del Ministerio de Educación.

Tempranamente, la crítica local emitirá los primeros juicios sobre su trabajo pictórico, alabándolo públicamente, destacando el conocimiento que la autora construyó como investigadora y artista, siendo sus pinturas una especie de documentos etnográficos que dan cuenta de características culturales de la cosmovisión mapuche, tanto en sus expresiones materiales como también en el estudio psicológico que enfrentó a través de su extensa obra retratística.

Esta modernidad temprana reprodujo la inspiración eurocentrista que le dio origen en el siglo xIx a la ciudad de Temuco e inspiró a sus habitantes. Sin duda este modo de visualizar el progreso de una nación tuvo su raíz en el proyecto nacionalista que se afianzó en el contexto de la celebración del centenario del país, momento en que surgieron profundas tensiones respecto de lo que significó el «ser chileno». Este afianzamiento de la chilenidad de ningún modo consideraba el valor concreto de los pueblos ancestrales, los cuales se invisibilizaron notoriamente en todo contexto de la vida cotidiana. El proyecto modernizador de Temuco se ve, hasta el día

15 El término reducciones hace alusión al proceso de reducción territorial del pueblo mapuche por parte del Estado chileno, que los agrupó de forma arbitraria en pequeños espacios territoriales muy distintos a los que ellos utilizaban tradicionalmente (Ferrando 2012). 
de hoy, constatado en la proyección arquitectónica que se debió impulsar luego del gran incendio de la ciudad, ocurrido el año 1908, que obligó un complejo proceso de recostrucción y rediseño urbano de la ciudad. Este programa estuvo inspirado en los paradigmas neoclásicos instalados por Benjamín Vicuña Mackenna ${ }^{16}$ para el proyecto urbanista de la ciudad de Santiago de Chile, mientras fue intendente de la capital entre 1872 y 1875.

Escasamente, se visualiza en los medios de comunicación de la época el interés en instalar públicamente la discusión respecto del valor e importancia de la cultura mapuche en la construcción de la identidad nacional. Sin embargo, destacan algunas iniciativas que surgen del ámbito público, como lo es en 1952 la instancia de cooperación entre las gobernaciones de Cautín y Malleco ${ }^{17}$ para coordinar a través de un comité ad hoc la creación de un monumento a La Araucanía, con el objeto de llevar a la realidad un viejo anhelo en «homenaje a la raza Araucana, cuyas grandes gestas honran las páginas de la historia de Chile» (El Diario Austral 1952). Este monumento se pretendía realizar en piedra o bronce y sería financiado a través de una colecta nacional que reuniría los fondos necesarios para su ejecución. Dicho monumento jamás fue llevado a cabo.

\section{SU PRODUCCIÓN INTELECTUAL}

No solamente óleos, dibujos y frescos emergieron de la mano de Celia Leyton; una de las características que destacaron en el trabajo de esta artista fue la capacidad que tuvo de producir textos que dieran cuenta de sus procesos reflexivos y creativos. Su capacidad de gestión le permitió contar con el apoyo de connotados intelectuales y críticos de arte de la época, que escribieron acerca de su producción.

En cada uno de sus textos cuenta con imágenes que, acompañadas de relatos descriptivos, dan cuenta del contexto y los personajes que constituyen parte central de ellas. Víctor Camacho, pintor y crítico de arte, consigna que «la pintura de Celia Leyton tiene el significado de un comienzo por incorporar a la pintura chilena un trozo de su personalidad nacional. Lo araucano no es sólo un tema más de colorido pictórico, sino un aspecto insospechado que linda con lo más genuino de nuestro espíritu» (Leyton 1968).

Entre sus textos destaca Araucanía, rostros de una raza altiva, realizado en 1945, libro-catálogo que hace referencia a su producción visual y pensamientos e ideas que de su experiencia investigativa han decantado en el documento impreso. Este libro, que incluyó ilustraciones a color, se agotó rápidamente (Cortés 1953), lo que la obligó a producir una nueva edición en 1953.

16 Benjamín Vicuña Mackenna (1831-1886). Escritor, periodista, político e historiador chileno. Americanista y defensor de la modernidad, fue responsable de variados planes de modernización urbana en la capital y otras ciudades de Chile. Fuente: http://www.memoriachilena.gob. $\mathrm{cl} / 602 / \mathrm{w} 3$-article-561.html.

${ }^{17}$ Cautín y Malleco son las dos provincias que componen la Región de La Araucanía. 
Por otra parte, Rupandungú es su producción más extensa y donde se registran los datos biográficos más importantes junto a sus impresiones, relatos y análisis. Fue editado por ella misma en el año 1968 e impreso por Editorial Universitaria en Santiago de Chile. Básicamente un texto autobiográfico, Rupandungú según la autora significa hechos pasados, de ahí su aproximación lingüística al concepto propio del mapudüngun ${ }^{18}$. Este proyecto no buscó ensalzar el propio nombre, ni reforzar su propia identidad, ni dejar elementos de su universo personal dispuestos a la trascendencia. Según plantea la misma autora, este libro debía operar como un dispositivo que acercara a las personas al mundo y al valor de la cosmovisión mapuche. Concretamente, Celia Leyton indicó que su obra pictórica tiene una utilidad central que es servir de puente afectivo con el mundo mapuche, para poder devolverle un valor perdido por la historia de abusos acaecidos. Otro dato interesante en esta producción anexa a su trabajo plástico visual es que está creado de modo tardío a la data de la mayoría de los hechos ahí descritos, por lo que es una creación que surge desde la "memoria» propiamente tal, lo que sin duda idealiza algunos pasajes y situaciones experimentadas.

El prólogo de Rupandungú fue escrito por Amanda Labarca, distinguida académica de la época, con un muy alto perfil público de intelectual activista, siendo ella una de las precursoras del feminismo latinoamericano. Amanda Labarca y Celia Leyton pertenecieron a una misma generación, y por lo mismo compartieron similares retos. Ambas impulsaron sus carreras como un modo de reaccionar contra el profundo tradicionalismo patriarcal que guiaba el sentido de numerosas familias chilenas en ese entonces.

No ha habido rey que sujetase esta soberbia gente, libertada, ni extranjera nación que se jactase, de haber dado a sus términos pisada. $\mathrm{Ni}$ comarcana tierra que se osase mover en contra y levantar espada siempre fue exenta, indómita, temida, de leyes libre, y de cerviz erguida (Ercilla en Leyton 1968).

Con esta cita del canto primero de La Araucana, obra poética cumbre de Alonso de Ercilla ${ }^{19}$, da inicio a este relato, simple en su conceptualización y profundamente dinámico y transparente en su redacción, dando cuenta de sus fuentes de inspiración, sus inicios en el arte, la docencia, su paso por la academia chilena,

${ }_{18}$ Lengua tradicional de la cultura mapuche (De Augusta 2017).

19 Alonso de Ercilla y Zúńiga (Madrid 1533-Toledo 1594). Soldado, poeta e historiador español. Permaneció 17 meses en el sur de Chile como efectivo militar en la Guerra de Arauco. En esta época escribió el poema épico La Araucana, obra considerada fundacional en el imaginario literario y poético chileno. http://www.memoriachilena.gob.cl/602/w3-article-3285.html. 
exposiciones, viajes y su intensa experiencia en el campo de la pintura mural, entre otros aspectos de su agitada vida como promotora y gestora cultural.

En 1950 produjo algunos textos-catálogos de su obra Raza Araucana, 8 pinturas de Celia Leyton, que contienen imágenes y pequeños textos introductorios. Estas publicaciones de divulgación fueron creadas por Celia Leyton para ser estudiadas por los niños, con el afán de entregar una visión objetiva y descriptiva de las características de la cultura mapuche, entendida como una base fundamental de conocimiento para la formación escolar chilena. En este mismo sentido, algunos de los textos fueron traducidos al inglés y al francés, para así facilitar su difusión fuera del país.

\section{EN TORNO A SU OBRA}

Sin duda un aspecto fundamental en la trascendencia de la obra de Celia Leyton hace relación con las distintas fases de desarrollo de su planteamiento estilístico, o mejor dicho, el modo en que ella va comprendiendo las complejas relaciones entre estilo, técnica y estética con que se enfrenta la pintura moderna. Sin duda, las metodologías académicas que conoció y experimentó desde el inicio de su formación pictórica fueron influyendo positivamente en su visión artística.

Celia Leyton tuvo oportunidad de ser formada por maestros provenientes del sistema academicista, pero que, sin duda, a esas alturas ya eran considerados referentes fundamentales para la pintura moderna y vanguardista chilena. Pedro Rezka Moreau influyó profundamente en el modo de pintar de Celia Leyton. En Rupandungú la autora lo recuerda con esta frase: "¿Y eso qué? Se puede dar diez, veinte, treinta y más sesiones; la importancia está en preparar bien, saber la calidad del empaste cada vez que se pinta, y dibujar pintando» (Leyton 1968).

«Dibujar pintando»... Visiblemente esta declaración orienta su planteamiento técnico plástico, el cual desde lo intuido se aproxima a una concepción crítica de la representación visual que se aleja del antiguo procedimiento canónico inspirado en la declaración "pintar lo que se sabe del objeto», para así transitar a la idea de pintar «lo que se ve» del objeto. Esta noción del arte visual surge de la revolución pictórica iniciada en Francia por Édouard Manet, quien dio pie al desarrollo del movimiento impresionista, con toda la revolución técnica, procedimental y conceptual de la pintura que, a estas alturas, ya contaba con un respaldo medianamente oficial en los círculos pictóricos. Evidentemente en el tardío circuito regional chileno, esta manera de entender la pintura no va en la misma línea proyectiva del arte oficial en la academia chilena de principios de siglo.

Todo este relato de esfuerzo de taller se ve ensombrecido por un episodio violento por parte del pintor Juan Francisco González; al parecer, con gritos e improperios destruyó un estudio que realizaba Celia Leyton en su taller. "¿Se ha creído Ud. que mi tiempo no vale, al perder mis enseńanzas, pintando cosas estúpidas, mamarrachos? No pedí perdón, porque habría sido contraproducente, pero mi arrepentimiento fue sincero» (Leyton 1968). Ella escribe con antiguo dolor en sus memorias. En esos mismos pasajes donde recuerda la amarga escena con su maes- 
tro, concluye que quizás por esta razón no estuvo entre las seleccionadas para obtener una beca de estudio en París.

El proyecto estético-simbólico de Celia Leyton es destacado por los medios de la época por el alto carácter promotor y de difusión de los valores culturales mapuches, interés que trascendió las fronteras nacionales. Celia Leyton emprendió proyectos de promoción internacional de su obra, cuyos esfuerzos sin embargo no siempre fueron exitosos. La gestión de sus exposiciones fue realizada generalmente de modo autónomo, donde aspectos como el financiamiento para los viajes, o los mismos trámites aduaneros a veces, le jugaron una mala pasada. "Trámites aduaneros argentinos me impidieron 'ventear' a mis mapuches en Buenos Aires". Celia Leyton sólo pudo exhibir 6 telas» (El Diario Austral 1950b) de treinta y tres que ella tenía considerado exponer.

La inspiración indigenista, sensibilidad estética, simbólica y política que condiciona gran parte de la producción de arte vanguardista latinoamericano no fue ajena a los intereses de Celia Leyton. Sus primeros trabajos de estudio se desarrollaron durante dos meses en un taller ambientado como $r u c a^{20}$, en la localidad de Chol Chol, comuna cercana a Temuco. Estas sesiones de taller eran con modelos remunerados, lo que de alguna manera obligó a Celia Leyton a intentar distintas estrategias de diálogo intercultural para poder fijar los marcos de negociación que le permitieran contar con modelos mapuches. Según ella misma relata, es el lenguaje universal de la creación artística el que sirvió como espacio común en el cual surge el encuentro con la otra cultura, un espacio de confianza donde la dignidad, la honestidad y sobre todo el respeto sirvieron para establecer un programa de trabajo creativo donde, a fin de cuentas, lo pictórico se transforma en el medio para acceder a una cosmovisión para ella casi desconocida y por sobre todo fascinante.

Ya la suerte está echada y aquí observamos los cimientos del proyecto estético-político de Celia Leyton. Uno de sus objetivos más añorados en el plano de la difusión de su obra era que el Museo Araucano de Temuco adquiriera algunos de sus cuadros. Luego del reconocimiento público que le diera David Alfaro Siqueiros, en una exposición en Santiago, la Ilustre Municipalidad de Temuco decretó dos mil pesos para adquirir una pintura de Celia Leyton para estos fines. No obstante, fue prácticamente obligada a negociar la entrega de dos obras por este mismo precio. Sin embargo, como si fuera poco, luego la Municipalidad, en sesión edilicia, decretó dejar sin efecto la adquisición, ocupando entonces este dinero en la compra de dos vacas.

«Hay todavía en Temuco muchos mapuches, no tienen importancia los retratos de ellos, ni tampoco los ngnillatunes pintados, asistimos a ellos con frecuencia» (Leyton 1968). Esa era la visión que las autoridades de la época, públicamente y sin pudor, declaraban en su compromiso por hacer de esta una mejor región, una mejor sociedad y cultura. Sin embargo, según relató Celia Leyton, la Municipalidad de

${ }^{20}$ Ruca o ruka es una choza, casa o edificio propio de la cultura mapuche (De Augusta 2017). 
Punta Arenas adquirió estas mismas obras por el doble de la oferta inicial establecida en Temuco.

\section{ANÁLISIS DE LA OBRA AUTORRETRATO DE CELIA LEYTON MILLAKËYÉN}

Generar una propuesta artística desde la cosmovisión mapuche requiere de una reflexión con respecto a la legitimidad del discurso con el cual se enfrenta la dicotomía entre lo representado (cultura mapuche) y quien representa (artista), en un contexto complejo que considera un escenario político, económico y social bajo la perspectiva de la interculturalidad.

El ejercicio del reconocimiento no solo es parte inherente del ser humano, es el «existir» es el yo que se asume diverso, complejo, no siempre, me parece, lúcido en su diversidad íntima y social. Es quizás allí donde se escriben y producen las imágenes de una memoria colectiva que un pueblo puede hacer y las imágenes de una memoria particular que con los aleas y líneas de fuga (personales y colectivas) de la historia resurgen en nuestro pasado y presente.

El reconocimiento sería entonces no solamente un ejercicio para ser sino que también para responder a la pregunta: ¿quien soy? ¿cual es mi retrato? (Chihuailaf 2015).

El autorretrato de Celia Leyton firmando con el seudónimo Millaküyén ${ }^{21}$ se presenta con vestimenta de mujer mapuche, obra que se distingue como portada del catálogo de Raza Araucana, 8 pinturas de Celia Leyton. En este ejercicio plástico, la artista busca situar su imagen (autorretrato) desde una posición de reconocimiento, respeto y pertenencia a la cultura mapuche.

Inicialmente se abordará el análisis de la pintura desde su firma que inscribe el deseo de ser en legitimidad; marca establecida como pseudónimo Millakëyén y que se encuentra como referencia en su libro Rupandungú de la siguiente manera: «Entre mis recuerdos gratos de esos tiempos está aquel en que por primera vez Nanco Catrinao de Carén, me llamó "Millakëyén" nombre que tomé por seudónimo. Me satisfizo su significado, "Luna de oro"” (Leyton 1968).

Esta obra pretende representar una síntesis de los elementos simbólicos y estéticos que logró identificar en las diversas investigaciones en terreno, incorporando en el cuadro su orgullo al portar vestimenta, tejidos, platería y colores de la raza araucana. Celia Leyton Millakëyén en su autorretrato señala los códigos interpretados desde la riqueza (platería) de la naturaleza (simbología) del territorio y cosmovisión mapuche.

${ }^{21}$ Millaküyén firmada en la pintura difiere de Millakëyén mencionada en su libro Rupadungún, que significa «luna de oro», al igual aparece en el catálogo Raza Araucana, 8 pinturas de Celia Leyton, titulada como Millahüyen. 
En el análisis de esta obra se observan distintas áreas que poseen una fuerte carga simbólica y que se representan de manera intensa a través de la práctica pictórica de la artista. La incorporación de tejidos y platería mapuche en la pintura son metáforas y claves para una lectura más amplia del contexto cultural mapuche.

En la imagen pintada destaca la representación de la forma de un trariwe $^{22}$ como centro de interés, tanto por el área que ocupa en la composición como también por la densidad cromática y simbólica que representa. La investigadora Susana Chacana señala:

El trariwe es una prenda altamente significativa dentro del mundo femenino mapuche. La mujer teje para ella y otras mujeres, es un elemento protector, firme y bello, para la fuerza en la cintura y el vientre materno. Protegerse fajándose implica proteger lo interno de posibles males externos, corrige, endereza. Además, este útil elemento otorga información cultural específica sobre la definición y/o valoración de la posición social de quien la lleva (Chacana 2012).

En el trariwe se pueden observar diseños con estructuras antropomorfas y fitomorfas donde destaca el lukutue ${ }^{23}$. Figura que "[...] corresponde a un "personaje ritual asexuado, representación de los participantes de la gran rogativa, Nguillatún". La voz Lukutuel significa "el arrodillado" y se constituiría por desdoblamiento" (Montecinos 1995). En este sentido, Celia Leyton utiliza este diseño simbólico del lukutuel como un elemento central de la composición del retrato, haciendo alusión a la estratificación social de la cultura mapuche.

El trariwe es representado de manera dinámica y descriptiva en sus formas, en la interpretación que hace su pincelada con pigmentos al óleo rojo carmín y blanco, en gestos de color puro y en un dibujo descriptivo. Predomina el uso del color rojo de acuerdo al testimonio de Matilde Painemil: «Tiene que ser rojo oscuro, una forma de trariwe que llevan las mujeres es una forma de proteger, es más para protegerse de la naturaleza, entonces por eso pusieron rojo oscuro, por que el rojo siempre protege de la maldad» (Chacana 2012).

Otro aspecto importante a destacar en su pintura es la incorporación de elementos de la platería tradicional mapuche, que identifican la zona territorial, el estrato social y familiar que la mujer posee dentro de esta cultura.

22 Trariwe o faja de cintura femenina mapuche de alto contenido simbólico, de acuerdo a creencias ancestrales se utiliza como un objeto de protección, el cual es elaborado principalmente por mujeres.

${ }^{23}$ Símbolo antropomorfo que aparece en los diseños textiles realizados en la cultura mapuche, especialmente en la faja femenina denominada trariwe, y que representa un personaje asexuado. En el lukutuel sus partes serían: «Lonko (cabeza), Wisewel (cuerpo), Piuke (corazón) y Puñontrewa (pies y manos semejantes a las huellas de un perro). Esta figura, según está hipótesis, sufrirá una serie de transformaciones a lo largo del tejido de los cuales harán nacer a otras figuras como el Temu (un árbol ligado al poder de las aguas que están en su cercanía, las que dan salud a los recién nacidos que se lavan en ellas) o Rayen, la flor que simboliza la capacidad de fecundación femenina» (Montecinos 1995). 
La platería mapuche es uno de los fenómenos más característicos del desarrollo de la sociedad mapuche y es expresión concreta de su filosofía en estrecha relación con la naturaleza. Y es al mismo tiempo afirmación de opulencia demostrativa de su riqueza económico-ganadera en la que juega el papel fundamental y determinante la mujer mapuche como la poseedora de la continuidad y de la fecundidad de la vida en un plano de igualdad en su küyehtun (ciclo menstrual) con la luna (Painecura 2011).

Otros elementos importantes en la composición de la obra son el keltatuwe (prendedor de plata), el tralilonko (cintillo de cabeza) y los chaway (pendientes de plata), que son parte importante del ajuar femenino mapuche. Celia Leyton en su texto autobiográfico explica que «... Allí supe que el trapelacucha con un cóndor y tres hileras de monedas lo llevan solamente las casadas y que amarrar al trarilonco de plata con un rosetón de cintas blancas significa virginidad» (Leyton 1968). La utilización de artefactos propios del ajuar femenino da cuenta del conocimiento acabado de la autora acerca de estos elementos simbólicos, que, representados con riqueza y dominio técnico, construyen estructuras simples, directas y sobre todo luminosas.

El carácter dialogante de la artista a través de su autorretrato enfatiza la idea de pertenencia a una identidad cultural del pueblo originario, por medio de diversos objetos simbólicos que dan cuenta de una herencia cultural, territorial y de linaje fundamentales para la configuración social del pueblo mapuche.

Junto con su usual firma Celia Leyton Vidal, aparece en el cuadro autorretrato Millekëyen una segunda inscripción como Millakëyén (luna de oro), que contrapone un interés esencial para la artista acerca de su búsqueda identitaria entre ser chilena y ser parte del pueblo mapuche, interrogantes que ella experimentó a diario como artista y como mujer.

El legado pictórico de Celia Leyton no ha sido estudiado desde un punto de vista historiográfico, ni estético, ni formal, por lo que su inscripción en la historia del arte chileno está aún pendiente, reconociéndose su legado en ámbitos aislados y de limitada trascendencia. Causa y efecto es entonces hasta ahora la ausencia de una revisión sistemática de los alcances de su trabajo. Lo anterior podría explicarse por su apropiación de un estilo pictórico muy personal y tardío, anclado en paradigmas postacadémicos, ya superados por la vanguardia chilena de la primera mitad de siglo $\mathrm{xx}$, donde ya está en ese entonces instalada una discusión propiamente teórica sobre los alcances de la ruptura discursiva del arte plástico.

\section{CONCLUSIONES}

Celia Leyton centró su trabajo en retratos, paisajes y escenas costumbristas de la cultura mapuche, que la posicionan como una figura central de la corriente indigenista chilena, la cual fue reconocida por artistas, críticos de arte e intelectuales de la época. Si bien ella tuvo una formación académica como artista, es capaz de incorporar estos elementos en sus obras realizando una síntesis entre la tradición artística y los lenguajes modernos, incorporando elementos simbólicos propios de la cultura mapuche como una forma de reinterpretar y dar un sentido social a su obra. 
La importancia de revelar su trabajo está centrada en su capacidad de visualizar desde la corriente indigenista temáticas que desbordaban los límites del campo artístico, lo que ha permitido dar nuevas interpretaciones a las necesidades sociales, culturales, políticas y económicas de ese momento del pueblo indígena mapuche.

Recibido: 12 de febrero de 2020; ACEPTAdo: 15 de septiembre de 2020 


\section{REFERENCIAS BIBLIOGRÁFICAS}

Artistas Visuales Chilenos (2019). Alberto Valenzuela Llanos [Internet]. Museo Nacional de Bellas Artes [cited 2019 Sep 15]. Available from https://www.artistasvisualeschilenos. $\mathrm{cl} / 658 / \mathrm{w} 3$-article-40032.html.

Artistas Visuales Chilenos (2019). Juan Francisco González [Internet]. Museo Nacional de Bellas Artes [cited 2019 Sep 20]. Available from https://www.artistasvisualeschilenos.cl/658/ w3-article-78055.html.

Artistas Visuales Chilenos (2019). Pedro Reszka Moreau [Internet]. Museo Nacional de Bellas Artes [cited 2019 Sep 12]. Available from https://www.artistasvisualeschilenos.cl/658/ w3-article-39905.html\#bibliografia.

Bicentenarias mujeres en la memoria y en la historia de Chile (2010). Mujeres de la Araucanía. Celia Leyton [Internet]. Available from http://www.bicentenarias.cl/ms_celia_leyton.htm.

Chacana, S. (2012). «Diferenciadores de la textualidad y etnoestética femenina contenida en la colección de trariwe del Museo Regional de la Araucanía». Fondo de Investigación Patrimonial DIBAM.

Chinuailaf, G. (2015). «Habitar el mundo, el ejercicio del reconocimiento», en Diálogos. Arte contemporáneo y su reconocimiento intercultural. Santiago de Chile (Pontificia Universidad Católica de Chile): Centro Interdisciplinario de Estudios Interculturales Indígenas.

Cortés, N. (1953). «Mujeres que hacen noticias», en El Diario Austral. (17 marzo 1953).

De Augusta, F.F.J. (2017). Diccionario Mapudungún-Español. Español-Mapudungún (M. Rojas, ed.). Santiago, Chile: Centro de Investigaciones Barros Arana, Ediciones UC Temuco.

El Diario Austral (1950a). “También los indios son chilenos”, en Reigolil encontró Celia Leyton los más soberbios tipos Mapuches; no la dejaron pintar, pero vió un "Machitún”». El Diario Austral (5 febrero 1950).

El Diario Austral (1950b.) «"Tramites aduaneros argentinos, me impidieron 'ventear' a mis mapuches en Buenos Aires”; Celia Leyton V. sólo pudo exhibir 6 telas: desarrolló gran "labor cultural"». El Diario Austral (21 junio 1950).

El Diario Austral (1950). «A mediados de la semana venidera la pintora temuquense Celia Leyton exhibirá 22 cuadros en Concepción». El Diario Austral (5 diciembre 1950).

El Diario Austral (1952). «Cooperación de las Municipalidades de Cautín y Malleco ha solicitado el comité nacional monumento a Araucanía». El Diario Austral (6 enero 1952).

El Diario Austral (1962). «Concepción del correo indígena en el segundo mural de Celia Leyton. Será inaugurado junto con edificio de correos». El Diario Austral (7 enero 1962).

Ferrando, R. (2012). Y asi nació la La Frontera... Conquista, guerra, ocupación, pacificación. 15501900 (segunda ed.). Temuco: Ediciones Universidad Católica de Temuco.

Foerster, R. y Montecino, S. (1988). Organizaciones, lideres y contiendas mapuches (1900-1970). Temuco: CEM.

Hernández, A., Ramos, N., y Cárcamo, C. (2002). Mapuche Lengua y Cultura. Mapudungun Español Inglés. Santiago: Pehuén.

Huelen (1956). «Celia Leyton», en Diario Austral. (25 de marzo).

Leyton, C. (1968). Rupandungu (vol. 1). Santiago, Chile: Editorial Universitaria. 
Memoria Chilena (2020). Alonso de Ercilla y Zuñiga [internet]. Available from http://www.memoriachilena.gob.cl/602/w3-article-561.html.

Montecinos, S. (1995). Sol viejo, Sol vieja. Lo femenino en las representaciones mapuche. Santiago: Colección mujeres en la cultura chilena. Serman.

Painecura, J. (2011). Charu. Sociedad y cosmovisión en la Platería Mapuche (vol. 1). Temuco: Ediciones UC Temuco.

VARgas, C. (2019). Los aportes de Claude Joseph sobre el mundo mapuche: cultura material y fotografía del Museo Histórico Nacional. Bajo la Lupa. Subdirección de Investigación, Servicio Nacional del Patrimonio Cultural.

Zamorano, P. y Cortés, C. (2007). «Muralismo en Chile: Texto y contexto de su discurso estético». Universum. 22: 254-274. Available from https://dx.doi.org/10.4067/S0718-23762007000200017. 


\section{FIGURAS}

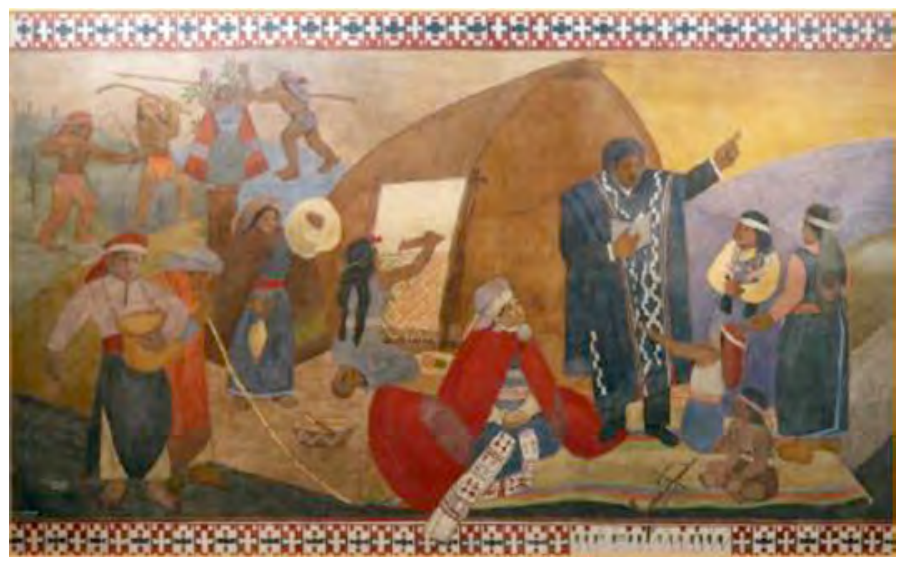

Figura 1. Celia Leyton. Profesor Neculmán. 1956.

Fresco sobre muro de concreto, 5,05 × 3,41 m. Liceo Gabriela Mistral, Temuco.

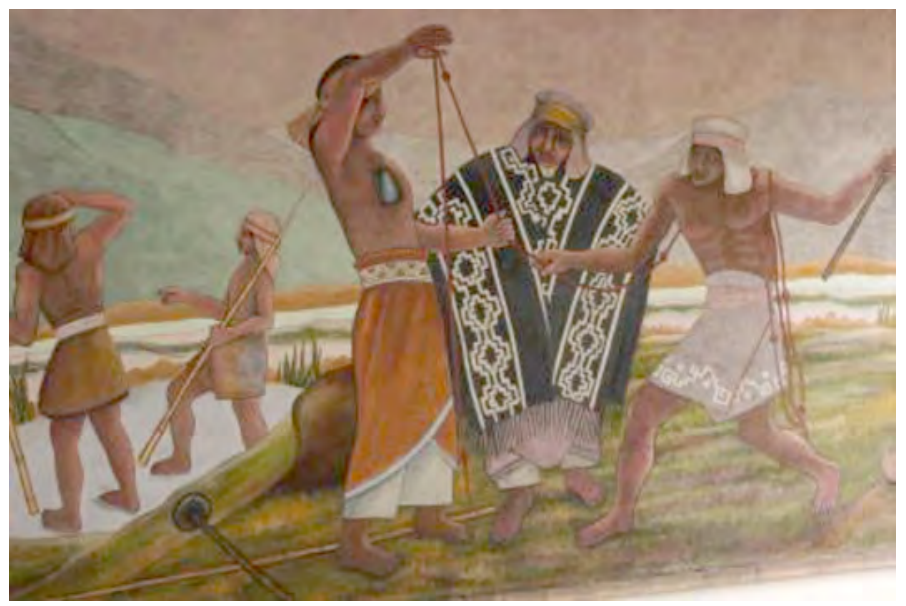

Figura 2. Celia Leyton. Chasqui. 1962.

Fresco sobre muro de concreto, 2,80 × 5,75 m. Correos de Chile en Temuco. 


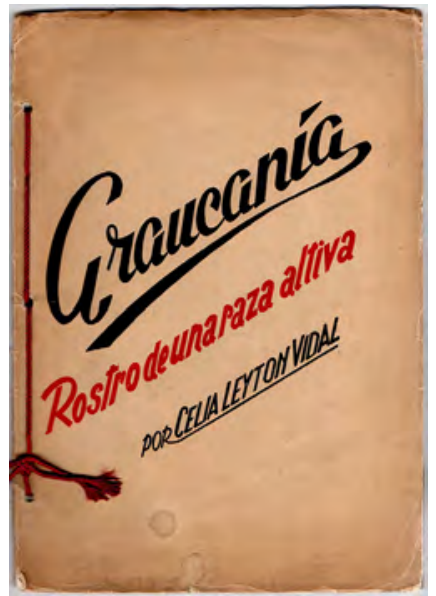

Figura 3. Araucanía, rostro de una raza altiva. Editorial Zig-Zag. 1945.

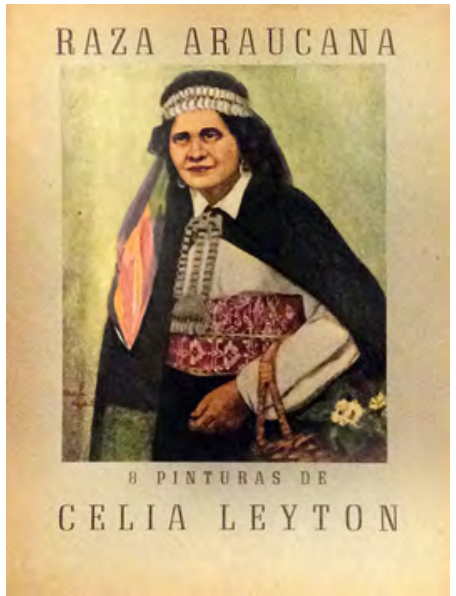

Figura 4. Raza Araucana, 8 pinturas de Celia Leyton. 1950.

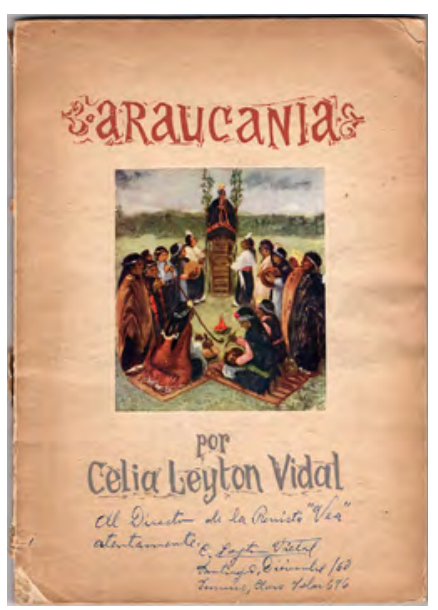

Figura 5. Araucania. 1953.

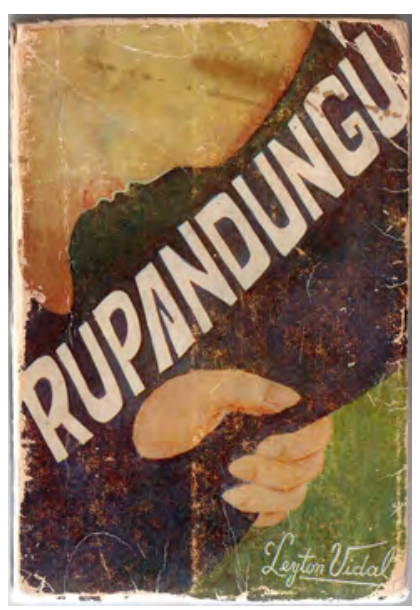

Figura 6. Rupandungú.

Editorial Universitaria. 1968. 


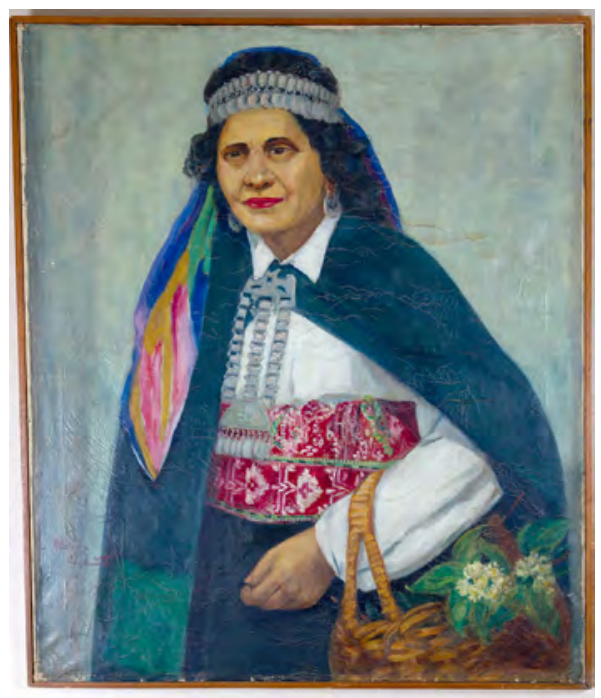

Figura 7. Autorretrato Millakëyen,

Celia Leyton, c. 1950 óleo sobre tela $72 \times 84$.

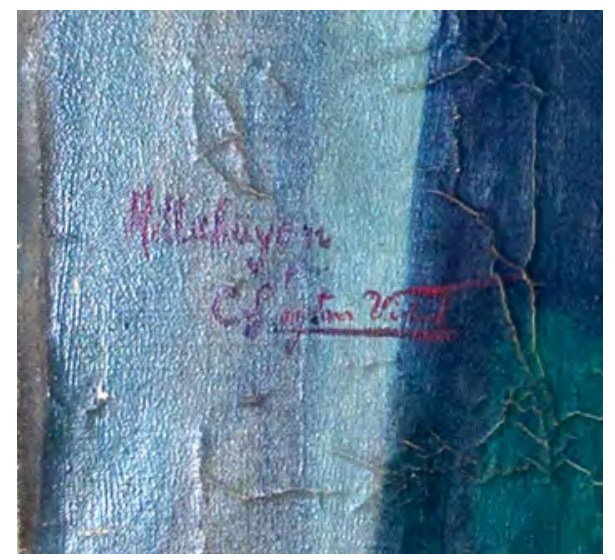

Figura 8. Detalle de firma en pintura donde se puede leer Millaküyén / Celia Leyton.

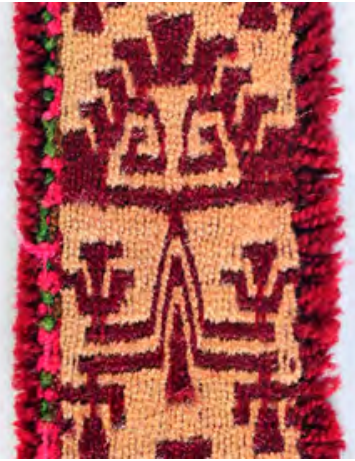

Figura 9. Ícono antropomorfo trariwe.

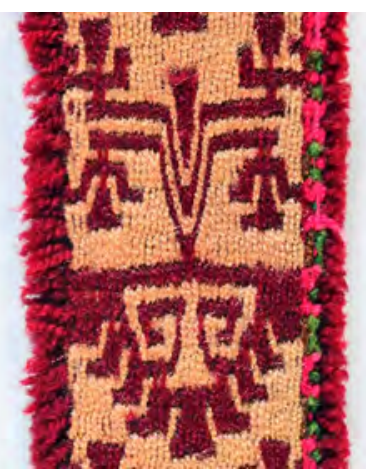

Figura 10. Ícono fitomorfo trariwe. 



\title{
PEDRO DE OBREGÓN Y LA MINIATURA TOLEDANA A MEDIADOS DEL SIGLO XVII
}

\author{
Jaime Moraleda Moraleda* \\ Universidad de Castilla-La Mancha \\ jaime.moraleda@uclm.es
}

\begin{abstract}
Resumen
En el siglo xvi la catedral de Toledo mantuvo un constante programa de mecenazgo en relación con el encargo de códices miniados para sus principales funciones litúrgicas. El Misal Rico de Cisneros, que supuso el inicio de la centuria bajo las pautas estéticas de la Escuela de Gante y Brujas, fue abriendo paso a una mayor incorporación de los repertorios all'antica, consolidados en el último cuarto de siglo, entre múltiples variantes del grutesco y novedosas composiciones renacentistas. La centuria del Setecientos se inició con los últimos trabajos para el Misal del Cardenal Quiroga, en el que Juan de Salazar trabajó como iluminador principal, muy influenciado por la corriente manierista imperante; si bien pronto advertimos un progresivo abandono en la producción de manuscritos iluminados, con grandes intervalos de ausencia de trabajos. La documentación consultada, que ha permitido un rastreo minucioso relacionado con esta actividad, revela la presencia del pintor madrileño Pedro de Obregón como uno de los últimos miniaturistas al servicio de la catedral primada, cuya obra, aún poco estudiada, presenta rasgos propios de las pautas estilísticas del Barroco, en un ambiente en el que se vislumbra una progresiva decadencia en el número de encargos relacionados con nuevos proyectos de iluminación.
\end{abstract}

Palabras clave: catedral de Toledo, Pedro de Obregón, manuscrito iluminado, Barroco.

\section{PEDRO DE OBREGÓN AND THE TOLEDANIAN MINIATURISM \\ IN THE MIDDLE OF THE 17TH CENTURY}

\section{Abstract}

Throughout the sixteenth century the Cathedral of Toledo continued its patronage program related to commission of illuminated manuscripts for its liturgical ceremonies. The Missal Rico de Cisneros, which marked the beginning of the century under the aesthetics of the School of Ghent and Bruges, opened the way to the incorporation of the all'antica repertoires developed in the last quarter of the century, under the multiple variants of the grutesco and the new Renaissance compositions. The seventeenth century began with the latest works for the Cardinal Quiroga's Missal, in which Juan de Salazar worked as the main illuminator, influenced by Mannerist aesthetics; although, we soon noticed a lower production of illuminated manuscripts, with large periods without works. The documentary investigation reveals the presence of the painter Pedro de Obregón, born in Madrid, as one of the last miniaturists in the service of the primated cathedral, whose work presents the main characteristics of the Baroque style, as well as a progressive decline of miniature works. Keywords: Cathedral of Toledo, Pedro de Obregón, illuminated manuscript, Baroque. 


\section{INTRODUCCIÓN ${ }^{1}$}

Las décadas finales del siglo Xvi recuperaron el esplendor de los trabajos de miniatura que habían brillado por su calidad y abundancia bajo el mecenazgo de los prelados toledanos (Fernández Collado 1999). La catedral primada, que aún vivía un periodo de notable protagonismo económico entre las principales sedes episcopales españolas, no desatendió la producción miniada, cuyo mejor ejemplo fueron los trabajos de escritura, iluminación y encuadernación para el Misal del Cardenal Quiroga (Moraleda 2018).

Gaspar de Quiroga y Vela, prelado desde 1577 a 1594, fue el último gran mecenas del siglo XVI, sustituido en la cátedra arzobispal por el archiduque Alberto (1594-1595), como se dejó constancia en la reseña de su fallecimiento:

En veinte de noviembre de 1594 murió el Illmo. y Rvmo. S. don Gaspar de Quiroga Cardenal Arzobispo de Toledo el cual en su vida tenía nombrado por coadjutor con futura sucesión en el arzobispado al serenísimo señor cardenal Archiduque Alberto sobrino del rey Phelipe nuestro señor ${ }^{2}$.

Durante su arzobispado hemos podido rastrear todos aquellos nombres vinculados con los trabajos de iluminación de manuscritos, según las cuentas de los libramientos del Archivo de Obra y Fábrica: Gaspar López, Pablo Ruiz, Andrés de Morata, Alonso el Rico, Ambrosio de Salazar, Juan Martínez de los Corrales y Juan de Salazar, si bien fueron los dos últimos los principales artífices de los trabajos de iluminación del citado misal, un conjunto de diez volúmenes ${ }^{3}$ que podemos considerar el principal encargo de producción miniada registrado en los documentos capitulares a finales de la centuria (Moraleda 2018).

Martínez de los Corrales, capellán del coro de la catedral de Toledo, trabajó entre 1580 y 1590 al servicio de cabildo toledano. Entre sus obras destaca la decoración de un epistolario, un capitulario y los dos primeros tomos del Misal de Toledo. Tras su fallecimiento los encargos corrieron a cargo de Juan de Salazar, quien estuvo decorándolo hasta su muerte en 1604, por lo que el manuscrito fue iniciado bajo el mandato del cardenal Gaspar de Quiroga (1577-1594) y concluido a principios del siglo XVII, con Sandoval y Rojas como arzobispo (1599-1618 ${ }^{4}$. Desde el año 1600 los pagos a Salazar no sólo se realizaron en función de las entregas tasadas, sino como asalariado de la Obra, según consta en el registro de libramientos,

${ }^{1}$ Este estudio se enmarca como parte del proyecto de investigación Toledo e Italia. Relaciones artísticas de ida y vuelta (ss. XVI-XVIII), (SBPLY/19/180501/000311), coordinado por la profesora Palma Martínez-Burgos García (Universidad de Castilla-La Mancha).

${ }^{2}$ Archivo Capitular de Toledo (=ACT). Archivo de Obra y Fábrica (=OF) 897, folio 1.

3 Seis volúmenes estaban destinados a la lectura en el lado de la Epístola y los cuatro restantes al lado del Evangelio.

${ }^{4} \mathrm{Al}$ revisar los últimos cuadernos del códice, podemos advertir la presencia de algunos trabajos de miniatura sin concluir, apenas esbozados, lo que pudo verse motivado por la ausencia de relevo artístico tras la muerte de Juan de Salazar. 
de esta manera recibía todos los años dos mil maravedís como iluminador, según interpretamos del siguiente texto capitular: $\mathrm{Ha}$ de aver juan de Salazar iluminador 2000 maravedis de salario en cada año, por tercios.

Nunca antes, ni en los momentos de máxima actividad, se había introducido un gasto anual por tareas de iluminación, como sí había ocurrido en las actividades de pintor, escultor, incluso para oficios menores como el de relojero. Quizá la figura de Juan de Salazar y el arte magistral de su obra hizo necesario un reconocimiento con el que asegurar su compromiso con la catedral, pues en décadas anteriores la itinerancia de miniaturistas entre los principales centros civiles o eclesiásticos fue la norma y no la excepción (Muntada 1992).

Tras el libramiento de 1603, por el que se abonaron a Salazar mil trescientos cuarenta reales, no se volvieron a registrar pagos por estos menesteres hasta 1609 , aunque nunca más a su persona, que de igual manera desaparece de los registros del salario anual. Sin duda hemos de pensar que le sobrevino la muerte a quien fuera uno de los grandes iluminadores del siglo Xvi en Espańa, idea que compartía Ceán Bermúdez (1800):

Salazar (Juan de) iluminador. Trabajó con fray Andrés de León y fray Julián de la Fuente del Saz en los libros del coro del monasterio del Escorial. Concluida esta gran obra pasó a Toledo, y el cabildo de la catedral le encargó el ańo de 1590 siguiese trabajando en un juego de misales, que había principiado en 1583 el clérigo Juan Martínez de los Corrales, del que solo iluminó los dos primeros tomos. Salazar trabajó en los restantes hasta 1604, que falleció en aquella ciudad, dexando la obra por concluir; pero digna de aprecio por la corrección del dibuxo, por la hermosura y limpieza del colorido y por los caprichosos adornos de buen gusto.

La obra del misal quedó inconclusa, lo que se puede apreciar en los trabajos de iluminación de algunos volúmenes, concretamente en los códices Ms. 56.6 y Ms. 56.9 (Janini y Gonzálvez 1977), donde se suceden varios huecos en blanco correspondientes a las letras capitales no iluminadas, o bien simplemente esbozado su ductus con pigmentos planos, fruto de una mano indiscutiblemente inexperta. Estos detalles consolidan la hipótesis de una especialización rigurosa del trabajo de ejecución del códice, donde el amanuense y el miniaturista, así como el encuadernador o el pergaminero, ejercían labores absolutamente independientes.

5 ACT, OF, 1601, fol. 90. 


\section{EL SIGLO XVII Y LA DECADENCIA EN LOS TRABAJOS DE ILUMINACIÓN: LAS FUENTES DOCUMENTALES Y SU INTERPRETACIÓN}

La decoración a través de colores planos y filigrana de tinta en algunas capitales se impuso desde los inicios de la nueva centuria, lo que corría en paralelo a una notable mengua en los encargos de libros manufacturados, multiplicándose la demanda de volúmenes impresos decorados con grabados (Fernández Collado et al. 2009). Incluso en aquellos ejemplares en los que se mantenía la elaboración manual de la escritura y su ornamentación, como fueron los grandes libros de coro para canto llano y polifónico, el despliegue de esmeradas orlas desapareció por completo, concentrándose exclusivamente la producción miniada en algunas de las principales letras de introito. El libro quedó finalmente despojado de su antiguo carácter suntuoso y decorativo, atractivo no sólo por lo que nos contaban las viñetas con historias catequéticas, sino por todo aquello que las envolvía; un elenco de virtuosas fanfarrias militares, grutescos, insectos y flores, monstruos y animales satíricos que sucumbieron con el paso de los años.

Los trabajos con los que se reanudaron las tareas de iluminar no fueron de envergadura, pues recayeron en manos de escribanos, cuya técnica no depurada generó una obra de escaso valor artístico. Así nos encontramos libramientos a favor del escribano Alonso de Morata, quien en 1604 acabó de escribir, apuntar e iluminar el tomo séptimo del Oficio de Tempore, así como los trabajos de letras grandes y mayores yluminadas en un libro intitulado de la açension visperas y maytines ${ }^{6}$ en 1609. Un caso semejante quedó anotado en los libramientos de 1611, cuando el escribano Eugenio de Mezquita recibió la cantidad de seiscientos seis reales y medio por los trabajos de escribir e iluminar en un libro de coro. No podemos afirmar con exactitud en qué volúmenes trabajó Mezquita, pues los datos del libramiento son verdaderamente escasos, si bien se conservan en la Biblioteca Capitular un número importante de salterios en los que aparecen algunas iniciales decoradas que denotan un manejo menos preciso de la técnica artística. La fuente documental de la Obra y Fábrica, aunque sucinta, ha sido de gran utilidad para contextualizar el proceso de declive de una de las más notables manufacturas que se había mantenido con un elevado nivel productivo a lo largo de las anteriores centurias:

En 14 de junio se libró al dicho eugenio de mezquita doscientos y noventa y quatro reales por haber escrito el officio de la Visitacion en dos libros que cada uno contiene treynta ojas veynte letras yluminadas una grande de dos renglones con dibujo y veintiocho quebradas como todo lo çertifica el Racionero Peńa corrector de los libros de canto en su relación que esta junto con la librança ${ }^{7}$.

\footnotetext{
${ }^{6}$ ACT, OF, 1609, Escribir y encuadernar, fol. 155.

7 ACT, OF, 1611, Escribir y encuadernar, fol. 151.
} 
Hemos de esperar a 1653 para encontrar de nuevo referencias documentales relativas a trabajos especializados de iluminación en manuscritos de uso litúrgico, lo que supuso un inmenso vacío temporal que ratifica el deterioro de la actividad y la decadencia de un arte que no volvió a recuperar su pretérito esplendor. Aunque se habían sucedido algunos pagos a Juan Ramírez de Arellano por escribir y reponer hojas en los libros para el coro, así como al librero Francisco García por sus encuadernaciones, no se trataba de profesionales de la miniatura. De igual manera podemos desgranar algunos libramientos por la compra de pieles, tanto para escritura como para encuadernación, pero nada de obras miniadas, ni referencias a miniaturistas. Finalmente, el 26 de octubre de 1653 se anotó el libramiento al pintor Pedro de Obregón, vecino de Madrid, quien recibió seis mil ochocientos maravedís por sus trabajos como iluminador en un salterio que estaba escribiendo Juan Ramírez de Arellano.

Los cambios que se produjeron en el Misal Romano desde 1604 con la Bula Cum sanctissimum Eucharistiae de Clemente VIII, así como los promulgados por Urbano VIII en $1634^{8}$, tuvieron importantes consecuencias que también afectaron a otros volúmenes de función litúrgica, pues los numerosos libros de canto que se habían escrito a los largo de los últimos años del siglo xvi y primeros del siguiente se vieron alterados con la intención de adaptarse a las correcciones, lo que generó el encargo de nuevos códices para el rito (Palacios 2018). En Toledo, los nuevos volúmenes fueron copiados por Juan Ramírez de Arellano, quien los concluyó en 1681, cuyo conjunto lo componen seis pares, aunque sólo los tres primeros se iluminaron con grandes vińetas realizadas por Pedro de Obregón (Ms. Cantoral 12.1A; Ms. Cantoral 12.1B; Ms. Cantoral 12.2A; Ms. Cantoral 12.2B; Ms. Cantoral 12.3A; Ms. Cantoral 12.3B), el resto de letras están decoradas con pigmentos planos y son de sencilla ejecución, por lo que las consideramos obra del escribano:

En 24 de mayo de 1653 ańos se libro a juan ramirez de arellano escritor de libros mill R de vellón que valen 34000 maravedis a quenta del salterio que esta haciendo para la obra conforme la escritura que tiene echa en 19 de febrero del año pasado de 52 y conforme la çertificacion que ba con la libranza?.

En 26 de octubre de 1653 años se libro a Pedro de obregón iluminador 200 reales de vellón que valen 6800 maravedis los quales son a quenta de lo que hubiere de haber por iluminar las letras del salterio que escribe juan ramirez... ${ }^{10}$.

Las notas del libramiento capitular nos sitúan ante la importancia de una escritura pública, previa al desarrollo de la actividad, un compromiso entre el artista y el comitente de notable importancia para poder rastrear las condiciones del acuerdo

${ }^{8}$ Con la Bula Si quid est, del 2 de septiembre de 1634, el pontífice mandó expurgar la edición de 1570 de errores tipográficos, cuya principal consecuencia fue la ejecución de nuevos volúmenes rectificados.

9 ACT, OF, 1653, Escribir y encuadernar, fol. 137.

${ }^{10}$ ACT, OF, 1653, Escribiry encuadernar, fol. 137v. 
entre las partes, así como la independencia o supeditación del miniaturista, y por consecuencia las características de la obra final (Revenga Domínguez 1999). En esta ocasión tenemos la fortuna de acceder al contrato por el cual Pedro de Obregón se obliga a iluminar las letras de un salterio de la Catedral Primada ${ }^{11}$. El interesante documento (Revenga Domínguez 1999), fechado el día 25 de octubre de 1653, presenta a las partes interesadas en el acuerdo; de parte del cliente consta Pedro López de Ynarra, obrero mayor de la catedral de Toledo, mientras que Pedro de Obregón actúa en su nombre como pintor. El texto nos permite rastrear las obligaciones a las que se vincula Obregón con la aceptación del contrato en base a una serie de disposiciones, en las que se resaltaba el uso de buenos colores y de buen oro y plata, la manera del pago, el plazo de entrega, así como la elección iconográfica para cada una de las capitales seleccionadas:

Primera letra duplicada del salmo que enpieça de Dixit Dominus, las a de hacer con su follaje adornada con toda perfeción y con una ystoria en medio de la letra de un David con la cabeça del jigante en una mano y con el montante en la otra. En otra letra duplicada de dilexit quoniam, la bisitación de Nuestra Señora. En otra letra duplicada que dice lietatus sum, la adoración de los reyes. En otra letra duplicada que dice ni si dominus edifica, la huida a Egipto. En otra letra duplicada, memento Domine David, la cena de Cristo con sus discípulos. En otra letra duplicada confitebontibi Domine, la entrada de ramos. En otra letra duplicada benedictus Dominus Deus meus, una Nuestra Señora con su Niño en los braços en pie. En otra letra duplicada cun ynbocaren, el sepulcro de Cristo con abad de Matías. En otra letra duplicada del oficio parvo de Nuestra Señora dixit dominus, una historia de Nuestra Señora ${ }^{12}$.

El siguiente año de 1654 se registró el último de los libramientos por iluminar los salterios del coro, momento en el que se pagaron cuatro mil trescientos reales de vellón, que sumados a los doscientos ya recibidos hacen el montante de cuatro mil quinientos, según consta en el contrato. Tras un balance económico de los costes por los trabajos de iluminación podemos concretar que recibió, por cada letra, la cantidad de doscientos cincuenta reales, lo que supone una tasación muy superior respecto de los pagos por historias que recibía Juan de Salazar, sólo cincuenta años antes. Si tomamos como referencia la historia de santa Águeda, iluminada por Salazar en 1592, recibió por ella doce ducados ${ }^{13}$, que equivalían a ciento treinta y dos reales; incluso en la tasación realizada por Luis de Velasco de una página completa con las armas del arzobispo Sandoval y Rojas, el trabajo fue valorado en doscientos reales $^{14}$, por lo que en ambos casos se constata la notable diferencia.

${ }^{11}$ Archivo Histórico Provincial de Toledo. (=AHPT), prot. 3.153, esc.: Rodrigo de Hoz, fols. 905-908.

12 AHPT, prot. 3.153, esc.: Rodrigo de Hoz, fol. 905.

13 ACT, OF, 893, Escribir y encuadernar, fol. 166v.

14 ACT, OF, 1603, Escribir y encuadernar, fol. 163. 
Las siguientes notas confirman la totalidad del pago por las dieciocho letras iluminadas en los dos primeros volúmenes del cuerpo del salterio (Ms. Cantoral 12.1A; Ms. Cantoral 12.1B), acorde con la escritura pública ante el notario Rodrigo de la Hoz, siendo testigos Juan de Llano, Joan Díaz y Gabriel de Romaní, vecinos en Toledo:

En 27 de mayo de 1654 ańos se libro a Pedro de obregón vecino de Madrid 4300 reales de vellon que valen 146200 maravedis con los quales y otros 200 que tiene recibidos en libranza a quenta en 26 de octubre del año proximo pasado de 53 se le pagan 4500 reales del precio de diez y ocho letras yluminadas que a echo para los salterios a razón de $250 \mathrm{R}$ cada letra conforme la escritura ante $\mathrm{R}^{\circ}$ de la hoz a 25 de octubre de $53^{15}$.

En adelante, sólo volvemos a encontrar referencias por partidas de iluminación en 1658, cuando se dejó constancia de un nuevo trabajo de Obregón, quien recibió la cantidad de dos mil quinientos reales pos sus iluminaciones en un psalterio de horas menores ${ }^{16}$ y que coincide con los trabajos de miniatura encontrados en los dos pares siguientes (Ms. Cantoral 12.2A; Ms. Cantoral 12.2B; Ms. Cantoral 12.3A; Ms. Cantoral 12.3B), con un total de diez letras iluminadas, aunque de esta partida no hemos hallado el contrato previo a la ejecución del libramiento.

Por su parte, el escribano Juan Ramírez de Arellano continuó como copista en los libros del coro, donde intervino decorando en algunas letras, como ha quedado registrado en los pagos de $1681^{17}$. Semejantes notas nos confirman el oficio de escribano y miniaturista de Manuel García Rodríguez en 1686, quien concluyó un nuevo libro para las oraciones de todo el año, en el que se le pagaron dos letras iluminadas, a 12 reales cada una ${ }^{18}$. En consecuencia, y acorde al seguimiento de las fuentes documentales consultadas, podemos confirmar la decadencia y progresivo abandono en el que se vio sumido el arte de la miniatura.

\section{PEDRO DE OBREGÓN: EL SEMBLANTE DE UN PINTOR E ILUMINADOR}

El pintor y grabador Pedro de Obregón nació en Madrid hacia 1597 y murió en la misma ciudad hacia 1670. Fue considerado por Palomino como uno de los mejores discípulos de Vicente Carducho y procuró imitar a su maestro en la corrección del dibuxo y en la fuerza del claro oscuro (Ceán Bermúdez 1800). Entre sus pin-

${ }^{15}$ ACT, OF, 1654, Escribir y encuadernar, fol. 168.

${ }^{16}$ ACT, OF, 1658, Escribir y encuadernar, fol. 159.

17 ACT, OF, 1681, Escribir y encuadernar, fol. 186v.

${ }_{18}$ El menor valor de tasación de estas letras confirma que se ha de tratar de trabajos ornamentales, no tanto de iniciales o viñetas historiadas, tal y como hemos considerado que sería la contribución de los escribanos en la iluminación de los códices. 
turas reconocidas destacan los lienzos de san Joaquín y santa Ana para el retablo de La Concepción de la parroquia madrileña de Santa Cruz, aunque la más renombrada pintura es el óleo que representa la Santísima Trinidad en el convento de la Merced Calzada, en la misma ciudad, todos ellos desaparecidos (Angulo Íńiguez 1983). El convento de Santa Clara de Villacastín (Segovia) conserva de su producción un óleo sobre lienzo con la aparición del Niño Jesús a san Antonio, semejante al que posee el Museo Nacional del Prado, fechado en 1633 y atribuido al mismo autor por Diego Angulo y Alfonso Pérez Sánchez. Observamos aquí, como efecto y herramienta del Barroco, un rompimiento de gloria sobre la figura del santo, donde una corte de ángeles músicos acompaña la imagen mística del Niño, para cuyo diseño Obregón siguió el modelo creado por Vicente Carducho para el mismo episodio místico, obra de 1631 conservada en el Museo del Ermitage (Pérez Sánchez 1992).

De sus trabajos como grabador, Ceán Bermúdez deja constancia en su diccionario (1800) de que posee dos ejemplares: una estampa pequeña donde figura una mujer (sic) sentada pintando y dos genios sosteniendo un pebellón y otra con el pasage de santo Domingo in Soriano, según modelo de un original de Alonso Cano. La Biblioteca Nacional de Madrid conserva un ejemplar de este último, así como otro cuya escena representa la imagen del rey Carlos II y Mariana de Austria, firmado por Obregón y publicado en la Nudrición Real de Pedro González de Salcedo en 1671 (Gallego 1999). La indefinida fecha del fallecimiento de nuestro autor ha generado dudas respecto de la autoría de la última estampa, si bien en mi opinión no es en absoluto descartable, pues, aunque Ceán Bermúdez apunta como fecha del deceso el año de 1659, no hemos encontrado ningún documento que lo pruebe, igual que tampoco existe nada al respecto de la hipótesis de 1669, defendida por otros, por lo que podríamos considerar el citado grabado, por ahora, como una de sus últimas obras.

Cuando Céan Bermúdez hizo referencia a un pintor homónimo en su compendio de artistas (1800), refiriéndose a él como iluminador para la santa iglesia de Toledo en 1564, expuso un dato que consideramos incorrecto, pues en nuestro vaciado documental, relativo a los miniaturistas que trabajaron para la sede episcopal toledana durante todo el siglo XVI, no aparece ninguna referencia con dicho nombre. Más entendemos la nota cronológica como un error tipográfico a la hora de transcribir las fechas, al cambiar 1654 por 1564 , por lo que a nuestro parecer sólo existe un autor con este nombre, cuyos trabajos para la catedral de Toledo quedaron registrados entre 1653 y 1658, como ya hemos dejado constancia de ello a través de las fuentes. El mismo error es recogido por Domínguez Bordona en su Diccionario de iluminadores españoles (1957), quien vuelve a situar a Obregón como miniaturista del siglo xvi. Esto nos llevaría a prescindir del apodo «el Joven" con el que se distingue a Pedro de Obregón, según recoge incluso el catálogo del Museo del Prado.

Las capitales iluminadas por Pedro de Obregón en los salterios de Toledo no coinciden con los repertorios habituales de la Escuela Toledana del primer tercio del siglo XVII, como Tristán, Orrente o Sánchez Cotán, en los que se fraguó un tratamiento tenebrista de la luz. Tampoco pretendió imitar los rasgos de su maestro Vicente Carducho, ni podemos ver en sus diseños las formas habituales de contem- 


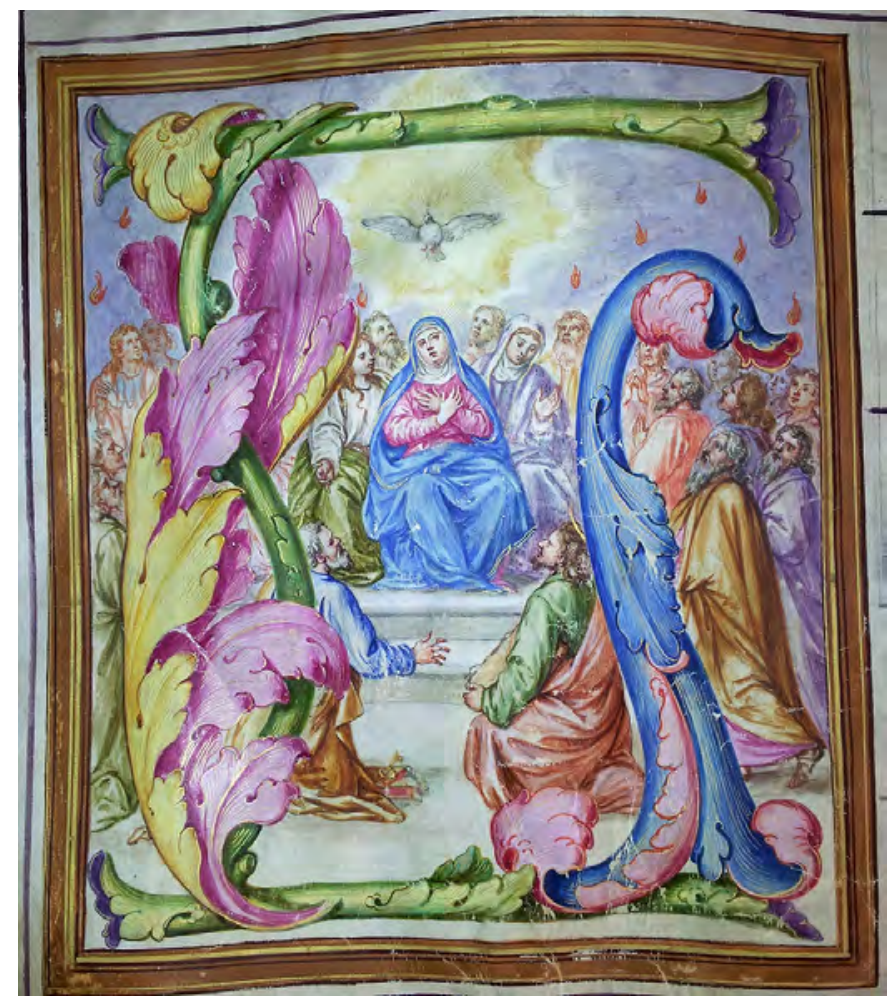

Figura 1. Pentecostés. Salterio de Toledo. Pedro de Obregón, 1654.

Biblioteca Capitular de Toledo.

poráneos como Antonio de Pereda (Urrea 1994). Obregón utilizó en sus miniaturas un estilo clasicista, muy decorativo y algo encorsetado, cuyas pautas conservadoras venían impuestas, en parte, por el condicionante técnico y espacial del objeto a decorar, donde no hay excesivas licencias a complejas composiciones, ni teatrales tratamientos (fig. 1).

El arte eclesiástico adquiere en el Barroco un carácter doctrinal que pierde sus rasgos espontáneos y subjetivos. La Iglesia, consciente de las licencias intelectuales a la hora de plasmar la imagen, pretendió un férreo control, dentro de una esfera lo más ortodoxa posible. El rigor doctrinal parece haber guiado la elección de Obregón en los modelos conservados en los salterios de Toledo, pues todas las escenas evidencian una ortodoxa y rigurosa conexión con los principios tridentinos de instruir en la verdad (González García 2015) (fig. 2).

Los episodios seleccionados para las capitales los hemos encontrado distribuidos en los referidos volúmenes del salterio de la siguiente manera: Ms. Cantoral 12.1A (David con la cabeza de Goliat, fol. 2r; la Epifanía, fol. 38v; la Última Cena, 


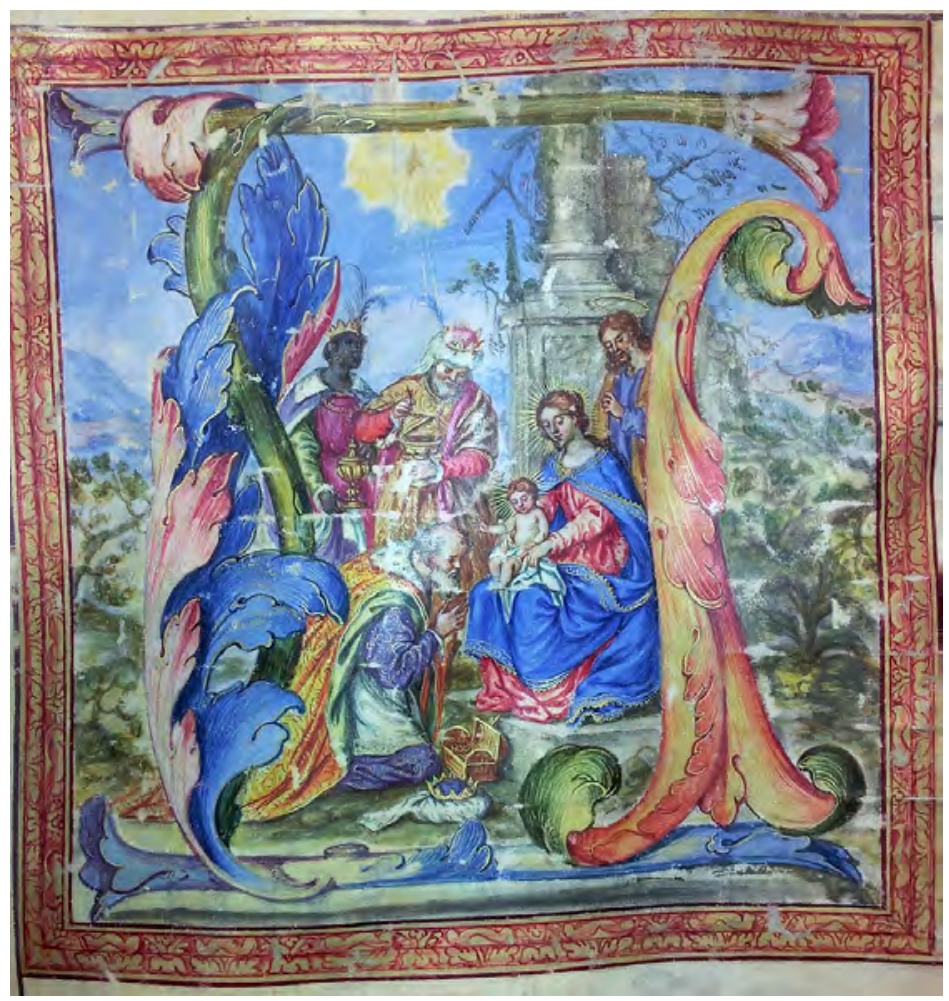

Figura 2. La Epifanía. Salterio de Toledo. Pedro de Obregón, 1654.

Biblioteca Capitular de Toledo.

fol. 61v; la Entrada en Jerusalén, fol. 81v; Madona con Niño, fol. 100r; y Santo Entierro, fol. 125r); Ms. Cantoral 12.1B (David con la cabeza de Goliat, fol. 4r; la Visitación, fol. 21v; la Epifanía, fol. 40v; la Huida a Egipto, fol. 52r; la Última Cena, fol. 63v; la Entrada en Jerusalén, fol. 83v; Madona con Niño, fol. 102r; el Santo Entierro, fol. 127r; y la Inmaculada, fol. 225r); Ms. Cantoral 12.2A (Ecce Homo, fol. 3r); Ms. Cantoral 12.2B (Ecce Homo, fol. 3r); Ms. Cantoral 12.3A (La Imposición de la casulla a san Ildefonso, fol. 6r; Pentecostés, fol. 47v; la Crucifixión, fol. 71r; y la lanzada de Longinos, fol. 93r) ${ }^{19}$.

Pedro de Obregón mantuvo una composición monumental, elaborada bajo un correcto dibujo y un brillante uso de la luz y del color. Ajeno a la dinámica

19 No hemos podido comprobar la relación de viñetas realizadas en el Ms. Cantoral 12.3B por encontrarse en proceso de restauración. 


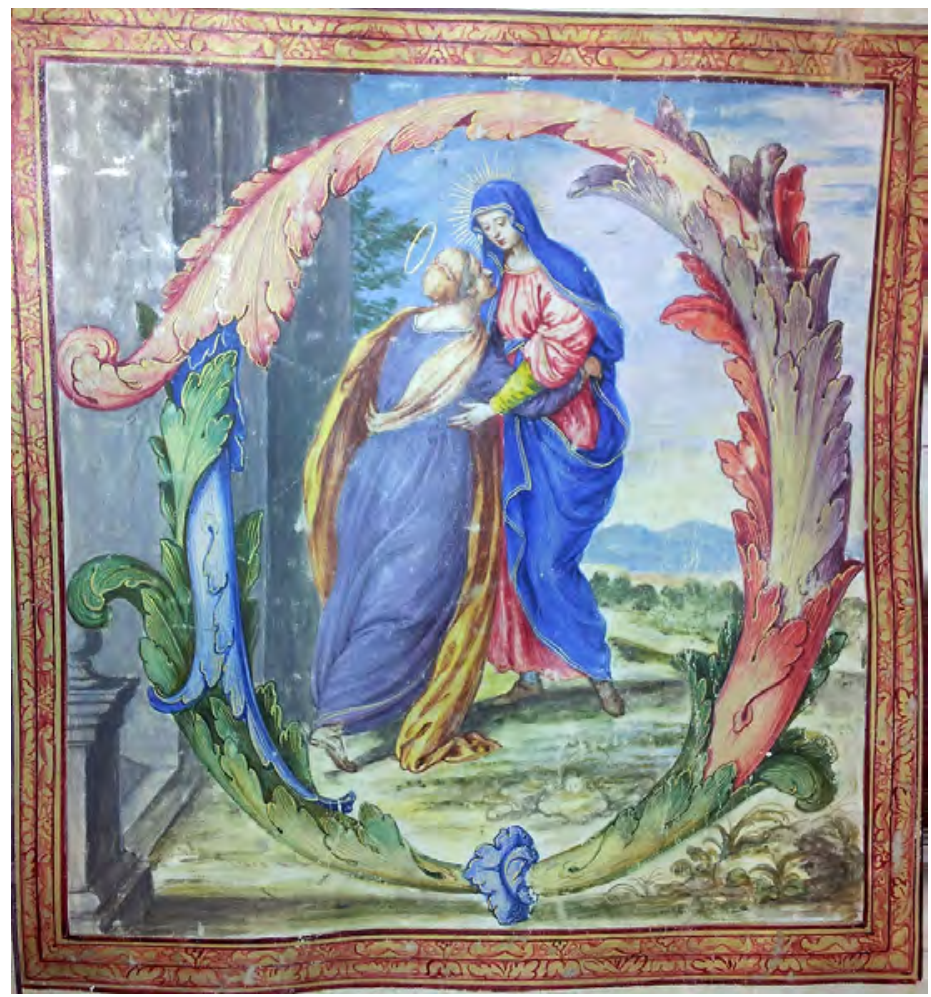

Figura 3. La Visitación. Salterio de Toledo. Pedro de Obregón, 1654.

Biblioteca Capitular de Toledo.

barroca naturalista, su obra en miniatura lo conecta con las composiciones serenas y elegantes de la última etapa de Alonso Cano, en el que también se producen esbeltas composiciones de diagonales y una delicadeza casi poética en los referentes iconográficos de temática religiosa. Partidario de las formas idealizadas, sin perder el dogmático «decoro» contrarreformista, se alejó de los modelos realistas, como observamos en la composición seleccionada para la escena de La Visitación (fig. 3).

El balance optimista ante el uso del color es ya el único recurso de suntuosidad al que se vincula la obra miniada, pues ha perdido su esmerado desarrollo de decoración marginal y se ha convertido en un pequeño cuadro con capacidad de ser analizado, estudiado y entendido de forma independiente, muy alejado del contexto medieval de códice iluminado (Muntada y Atienza 2003). La escena se organiza de manera clara, con una marcada corporeidad en las representaciones, reduciendo al máximo el número de personajes con la finalidad de facilitar la comprensión semántica de la obra. 


\section{CONCLUSIÓN}

Dos han sido los objetivos principales en el desarrollo de nuestra investigación: el primero pretendía hacer visible la labor artística en torno a los códices miniados del siglo XviI conservados en la catedral de Toledo. Como importante centro de creación artística, sus comitentes mantuvieron el encargo de nuevos códices manufacturados a pesar del amplio desarrollo de las técnicas de impresión. El simbolismo de suntuosidad y distinción intrínseco en la obra preparada, copiada e iluminada condujo a una pervivencia de los manuscritos miniados, si bien la centuria del Setecientos denota una progresiva decadencia tanto en el número de ejemplares encargados como en el de profesionales dedicados al oficio, así como en los importantes cambios ornamentales que habían singularizado la decoración de manuscritos a lo largo de los siglos medievales, incluso durante las primeras décadas del Xvi.

En segundo lugar, la aportación documental nos abría la oportunidad de ampliar la información relativa a uno de los pintores espańoles del siglo XVII, cuya escasez de datos biográficos dificulta la atribución y catalogación de sus trabajos. Nos referimos al madrileño Pedro de Obregón, quien ejerció como iluminador para la catedral de Toledo entre los ańos 1653 y 1658. Algunos errores arrastrados de las publicaciones decimonónicas, así como una dudosa hipótesis para su fecha de defunción, han generado una notable controversia a la hora de atribuir alguna de sus obras. Los datos documentales capitulares, así como las inequívocas iluminaciones elaboradas para los cantorales del coro toledano, contribuyen a seguir profundizando en su figura y trayectoria artística. 


\section{BIBLIOGRAFÍA}

Angulo ÍñIguez, D. (1983). La pintura madrileña del segundo tercio del siglo XVII. Madrid: Consejo Superior de Investigaciones Científicas.

CeÁn Bermúdez, J.A. (1800). Diccionario histórico de los más ilustres profesores de las bellas artes en España. Madrid: Imprenta de la Viuda de Ibarra.

Domínguez Bordona, J. (1957). Diccionario de iluminadores españoles. Madrid: Imprenta y Editorial Maestre.

Fernández Collado, A. (1999). La catedral de Toledo en el siglo XVI. Vida, arte y personas. Toledo: Universidad de Castilla-La Mancha.

Fernández Collado, A., Rodríguez González, A. y Castañeda Tordera, I. (2009). Catálogo de impresos de la Biblioteca Capitular. Toledo: Instituto Superior de Estudios Teológicos San Ildefonso.

Gallego, A. (1999). Historia del grabado en España. Madrid: Ediciones Cátedra.

GonzÁlez García, J.L. (2015). Imágenes sagradas y predicación visual en el siglo de oro. Madrid: Akal.

Janini, J. y Gonzálvez, R. (1977). Catálogo de los códices litúrgicos de la Catedral de Toledo. Toledo: Diputación Provincial de Toledo.

Moraleda Moraleda, J. (2018). Los códices iluminados para la catedral de Toledo. El esplendor del arte de la miniatura (s. XVI). Toledo: Cabildo Primado.

Muntada Torrellas, A. (1992). El Misal Rico de Cisneros. Madrid: Real Fundación de Toledo.

Muntada Torrellas, A. y Atienza, J.C. 2003. Cantorales del Monasterio de san Jerónimo de Espaja. Soria: Catedral de Burgo de Osma.

Palacios Blanco, F. (2018). El romano pontifice y la liturgia. Estudio histórico- jurídico del ejercicio y desarrollo de la potestad del papa en materia litúrgica. Toledo: Instituto Teológico san Ildefonso.

Pérez Sánchez, A.E. (1992). Pintura barroca en España, 1600-1750. Madrid: Ediciones Cátedra.

Revenga Domínguez, P. (1999). La Contratación de obras pictóricas en Toledo, 1650-1725. Cuadernos de arte e iconografía 8: 361-370.

Urrea, J. (1994). Pintores del reinado de Felipe IV. Madrid: Museo del Prado, Caja de Ahorros de Navarra. 



\title{
EXTRAÑAMIENTOS EN LA CIUDAD. DEL SHOCK URBANO A LAS DERIVAS SITUACIONISTAS
}

\author{
Nuria Vallespín Toro* \\ Universidad de La Laguna \\ nvallespin@hotmail.com
}

\section{RESUMEN}

Lo extraño siempre ha estado presente a lo largo de la historia. Explorando los vínculos entre disciplinas como la literatura, el cine, el arte, la sociología, etc., situamos el concepto de extrańeza como estado que acontece: como suceso imprevisto, como efecto de asombro, y sus derivaciones como lo extraordinario, lo raro, lo sublime, lo extranjero, las anomalías, el azar, etc. Desde los espacios de lo maravilloso extraño, como los Gabinetes de Curiosidades, las Cámaras de las Maravillas y las Fantasmagorías ligadas a los efectos especiales, nos centraremos en el extrañamiento en el contexto del ámbito urbano, representado por el flâneur como paseante distraído, por las derivas urbanas de los situacionistas con ciudades utópicas como New Babylon y sus cartografías experimentales y por personajes cinematográficos como Mr. Hulot, que construyen discursos poéticos sobre el extrañamiento de lo cotidiano. A través de ellos veremos cómo la ciudad se nos ofrece como el escenario de los acontecimientos donde se manifiesta la irrupción de lo extraño en toda su complejidad.

PALABRAs Clave: extrañamiento, derivas urbanas, diagrama, flâneur, ciudad.

EXTRANGEMENT IN THE CITY.

FROM URBAN SHOCK TO SITUATIONIST DERIVÉS

\section{Abstract}

The strange has always been present throughout history. Exploring the links between disciplines such as literature, cinema, art, sociology, etc. We place the concept of strangeness as a state that comes up: as an unforeseen event, as an effect of astonishment, and its derivations as the extraordinary, the rare, the sublime, the stranger, anomalies, random, etc. From strange wonder spaces, such as the Cabinets of Curiosities, Wonders Cameras and the Phantasmagorias linked to special effects, we will focus on estrangement in the context of the urban environment, represented by the flâneur as a distracted passer-by, by Situationists' derives with utopian cities as New Babylon and their experimental cartographies and by cinematographic characters such Mr. Hulot, who construct poetic discourses on the estrangement of the everyday. Through them we will see how the city offers itself to us as the scene of events where the irruption of the strange in all its complexity is manifested. KEYwORDs: estrangement, urban derives, diagrams, flâneur, city. 


\section{FRAGMENTACIÓN, SHOCKY DISPERSIÓN PERCEPTIVA}

El modo en que desarrollamos ciertas tareas, ya sean artísticas, productivas, creativas u otras más rutinarias y cotidianas como conducir, comer, etc., nos sitúa en una dimensión de la experiencia contemporánea que requiere que cancelemos o eliminemos de nuestra conciencia gran parte de nuestro entorno inmediato. Este argumento es defendido por el crítico de arte Jonathan Crary en Suspensiones de la percepción, donde afirma que nuestra capacidad para atender o prestar atención está basada en la capacidad de desconectarnos de los estímulos que nos rodean para concentrarnos y aislarlos en un reducido número de ellos. La percepción de los cambios sociales a partir del siglo XIX se ha caracterizado por la experiencia de la fragmentación, el shock y la dispersión. Con la aparición de las nuevas formas tecnológicas, las transformaciones de las ciudades tradicionales hacia grandes metrópolis provocaron cambios económicos y sociales revelando la existencia del «problema de la atención» (Crary 2008), que va más allá que entender al sujeto como mero espectador. Es Walter Benjamin quien asocia el concepto de «lo extraño» en Freud con la fantasmagoría de la vida urbana en DasPassagen-Werk (Libro de los pasajes) abordando lo extrańo y lo inquietante como aquello que nos es desconocido. (Benjamin 2005). El sentido freudiano de lo inquietante alude a «esa clase de miedo que lleva de vuelta a lo que se conoce de lo que es antiguo y familiar» (Freud 1988). Benjamin pone de relieve la crisis de la obra de arte y del artista, la irrupción de la multitud, del mercado, las transformaciones económicas, sociales, culturales y urbanas más importantes del siglo XIX, trazando un discurso sobre la modernidad. En el Libro de los pasajes, Benjamin reflexiona sobre los espacios en transformación de París, donde destaca su atracción gracias a su condición ambivalente entre interior y exterior, que permite al espacio exterior de las calles transformarse en un espacio interior que convierte a las calles en la vivienda de los colectivos sociales y al pasaje comercial en un salón. El hilo conductor es la ciudad y su arquitectura, asociadas al surgimiento de los pasajes comerciales. Se trata de grandes transformaciones urbanas en un incipiente desarrollo del capitalismo, con el inicio del uso del acero y el vidrio en la construcción, que conlleva una profunda transformación de las relaciones entre el arte y la técnica, los modos de producción, percepción y consumo del arte (figs. 1 y 2).

La burguesía de una París cambiante intenta desplazar las transformaciones urbanas al ámbito interior del salón, la ciudad y la calle, transformándose esta última en un escenario para el paseante, para el flâneur que la recorre. El flâneur es el nuevo protagonista de la modernidad; espectador-narrador de la transformación de la experiencia del espacio urbano de París.

* Doctora en Arquitectura por la Universidad de La Laguna.

1 Lo extraño es entendido por Freud como «lo contrario a lo que es familiar». La definición originaria propuesta por Sigmund Freud en 1919 señala que «the uncanny» es el sentimiento de inquietud que surge cuando algo familiar de repente se vuelve extrańo y desconocido (Freud 1988). 


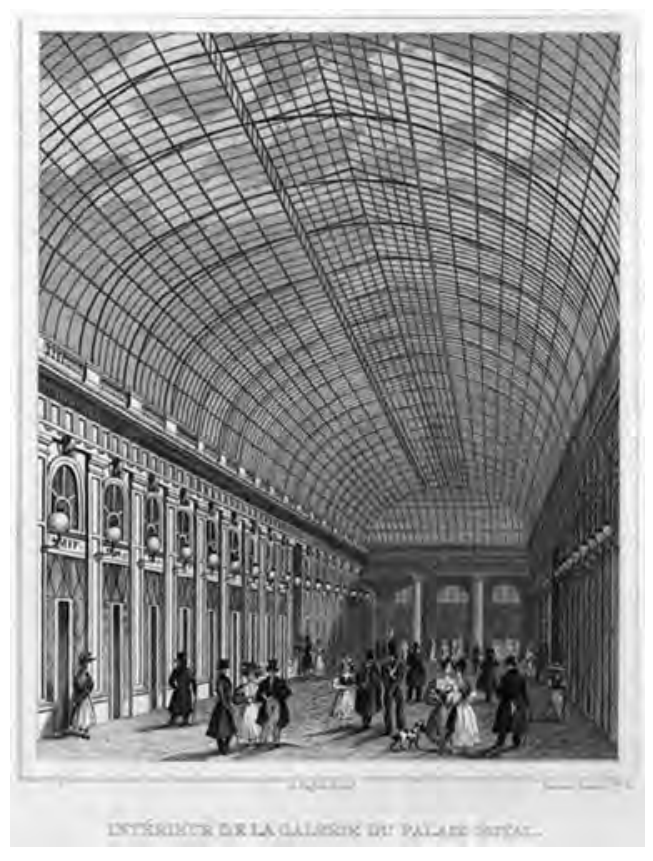

Fig. 1. Augustus Pugin, Galerie of the Palais Royal: interior in Paris, 1831, Brown University Library, USA.

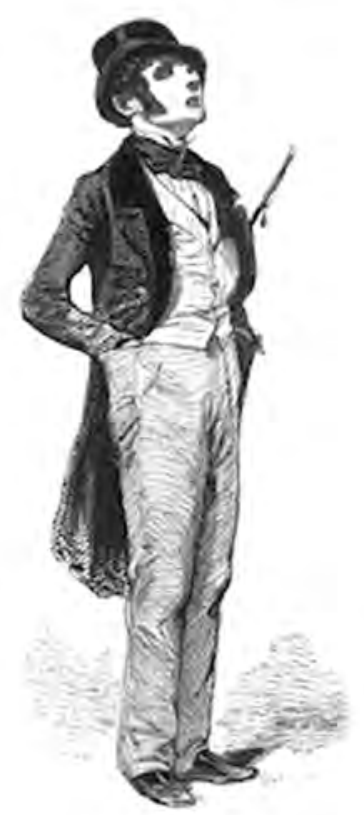

Fig. 2. Paul Gavarni, Le Flâneur, 1842, https://commons.wikimedia.org/wiki/ File:Rosler-LeFlaneur.jpg.

\section{TRÁNSITO A LA MODERNIDAD EN LA LITERATURA}

Pero no todos los sujetos de la modernidad se adaptaron de igual modo a los grandes cambios sociales. El fenómeno de extrañamiento o alienación que caracterizan al hombre moderno, que ha dejado de sentirse como en casa en el mundo que le rodea, ha sido abordado por la sociología y la literatura clásica y moderna, siendo el tema central de muchas obras literarias del siglo xx, en autores como Kafka, Sartre, Camus, Roth, T.S. Eliot, Hesse, Lawrence, Musil, etc.

Como apunta Martínez (1998) en su ensayo Anomia, extrañamiento y desarraigo en la literatura del siglo XX: un análisis sociológico, tanto sociólogos como novelistas, dramaturgos y poetas han tratado a lo largo de la historia de comprender e interpretar a través de sus personajes el tránsito a la modernidad en su vida cotidiana; desde Georg Simmel analizando la indolencia (actitud que él llama blasé) del hombre urbano que se protege con esa coraza de indiferencia de un medio ambiente agresivo e impersonal en Las grandes urbes y la vida del espiritu, (Simmel 1986) a la figura típica del flâneur, caracterizado por su actitud observadora y a la vez distanciada, y Mersault, protagonista de El extranjero, de Camus, igualmente distanciado e incapaz de establecer relaciones afectivas con el mundo que le rodea (Camus 2012). 


\section{AMPLIACIONES DEL ASOMBRO Y DISTRACCIONES EN LA CIUDAD MODERNA A TRAVÉS DEL CINE}

La arquitectura y el cine se caracterizan por compartir ciertas técnicas de extrańamiento que activan las percepciones del tiempo y el espacio. En este sentido, podríamos afirmar que el cineasta Jacques Tati recoge a lo largo de su filmografía una amplia reflexión sobre el tránsito de una arquitectura tradicional a una moderna, sobre su función y la vida asociada a la modernidad, desde un punto de vista crítico, pero no negativo. En la ciudad moderna descrita por Tati no hay lugar para la angustia o el terror, pero es a través de su protagonista, el carismático Mr. Hulot, donde se nos revela la deslumbrante e incomprensible relación con ella. A este respecto, algunos autores como Joan Ockman mantienen que Playtime (1967), de Jacques Tati, es «una reflexión caleidoscópica de la experiencia de la arquitectura del siglo xx y los sujetos que la habitan, en la brecha existente entre el modernismo y el postmodernismo» (Ockman 2011). A pesar de la interacción con el entorno, percibimos la alienación de una sociedad desde su espacio, lugar y tiempo. Jacques Tati pone el foco en los efectos despersonalizadores de la arquitectura moderna, representada a través de la tecnología mediante artilugios y desarrollos técnicos, en contraste con los valores de la ciudad tradicional, una ciudad desarrollada y altamente interactiva, donde los espacios de las calles son paisajes urbanos interconectados que mantienen la actividad social.

\section{MR. HULOT, EL FLÂNEUR DE LA CIUDAD MODERNA}

En el análisis sobre el filme Playtime, el concepto de distracción queda definido por un nuevo modo perceptivo presente en la modernidad, como una forma de experiencia que ocurre accidentalmente y en gran medida inconscientemente, más que a través de la atenta y contemplativa visión que tradicionalmente caracteriza la apreciación de la pintura, por ejemplo. Hay un componente óptico e intencional (uso y percepción) en la experiencia de la arquitectura. Para Walter Benjamin, ésta ha sido siempre prototipo de una obra de arte cuya recepción se da distraídamente: «No se podría juzgar exactamente la recepción de la arquitectura pensando en el recogimiento de los viajeros ante los edificios más célebres, pues no existe nada en lo que es la recepción táctil que corresponda a lo que es la contemplación en la recepción óptica» (Benjamin 2008). Está menos interesado, por tanto, en la actitud atenta de un turista ante un edificio famoso que en la práctica diaria por la cual la forma construida es comprendida por las masas trabajadoras en la ciudad o por el flâneur paseando por ella. Tanto en Playtime (1967) como en Mon Oncle (Mi tío, 1958), Trafic (1971) o en las Vacaciones de Mr. Hulot (1953), el protagonista es el flâneur baudelariano, el espectador distraído pero activo, que se enfrenta al mundo moderno, a una ciudad/casa mecanizada, a urbanizaciones ordenadas frente a barrios tradicionales, caóticos y desordenados (figs. 3 y 4 ).

Las experiencias supuestamente predecibles y controlables en la arquitectura moderna no siempre lo son, y el choque (o shock) que experimenta Mr. Hulot 


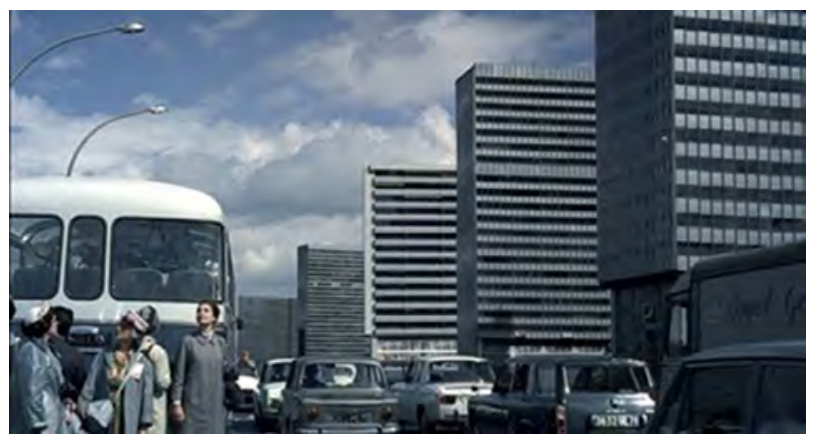

Fig. 3. Fotograma de Playtime, Jacques Tati, 1967.

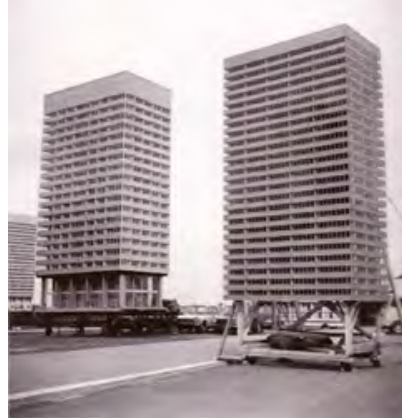

Fig. 4. Set de rodaje Tativille, diseñado por Jacques Tati y

Eugene Roman, 1967.
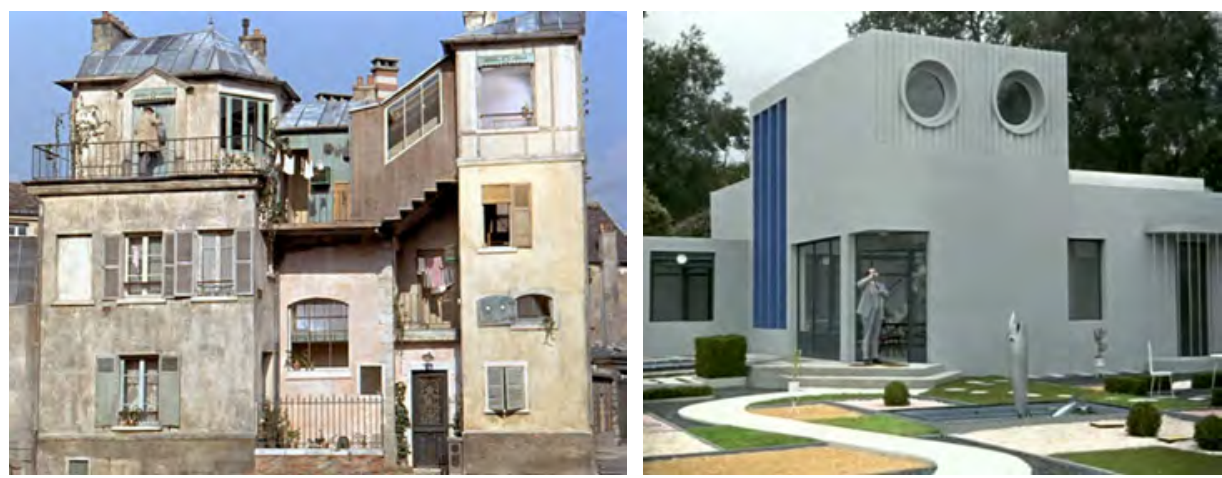

Figs. 5 y 6. Fotogramas de Mon Oncle, Jacques Tati, 1958.

en ella le convirtieren en un disyuntor del mundo que le rodea sin quererlo, en el que, de manera "distraída», produce situaciones inesperadas. Si bien en Mon Oncle el protagonista sigue habitando en el barrio tradicional para ir de visita a casa de su hermana, situada en un barrio ultramoderno, en Playtime, por el contrario, Hulot acepta la modernidad, la ciudad moderna, y empieza a «jugar» con ella. Pero lejos de distraerse y alejarse de este nuevo mundo que se le presenta inaprensible, es capaz de interactuar con él y adaptarse a sus nuevas reglas ${ }^{2}$ (figs. 5 y 6).

2 Concebido por Jacques Tati y diseñado por Eugene Roman, Tativille era una «auténtica» ciudad cinematográfica, nacida de las necesidades de la película: grandes bloques de viviendas, edificios de acero y vidrio, oficinas, carreteras asfaltadas, aparcamientos, aeropuertos y escaleras mecánicas. Unos 100 trabajadores trabajaron sin cesar durante 5 meses para construir este estudio revolucionario con particiones transparentes. 
En Mon Oncle y Playtime vemos cómo la experiencia de los espacios urbanos, tanto el tradicional como el moderno, son distintos, se contraponen. Los movimientos y sucesos en el espacio tradicional no responden a un orden o lógica, en el aparente «desorden pintoresco» siempre hay lugar para la sorpresa o lo inesperado.

Coincidente con el estreno de Playtime, Guy Debord, miembro fundador de la Internacional Situacionista, publica La sociedad del espectáculo (1967), donde realiza una audaz crítica de la sociedad capitalista, vista como un gran espectáculo, en el que cada aspecto de la vida diaria queda supeditado a las mercancías y al consumo. Las películas de Tati comparten muchas de estas ideas, y sus poéticas de distracción y el juego son reminiscencias de los experimentos de los situacionistas como la deriva, una manera de alcanzar una experiencia auténtica y un conocimiento emancipador a través de las denominadas «técnicas psicogeográficas».

\section{DERIVAS SITUACIONISTAS: REAPASIONANDO LA VIDA COTIDIANA}

Durante la década de los sesenta, en un contexto centroeuropeo de descontento hacia las formas de gobierno dominantes, surgen posicionamientos radicales que proponen nuevas relaciones identitarias entre los habitantes y el espacio urbano. Algunos autores, como Henri Lefebvre en La vida cotidiana en el mundo moderno (1984), y el Movimiento Situacionista, con Guy Debord como máximo representante, se rebelan en los años sesenta contra los postulados de una arquitectura funcionalista, dominada por un entusiasmo por la tecnología y un optimismo ante el futuro. Se manifiestan en contra de las propuestas de Le Corbusier para ciudades como La Ville Radieuse, de 1933, donde se decreta «la muerte de la calle» (Le Corbusier 1967), lugar innecesario que imposibilitaba las relaciones entre sus habitantes, reduciendo el problema del urbanismo a la movilidad con el objetivo de reducir los tiempos muertos entre las dos funciones fundamentales, que eran estar en casa e ir a trabajar (enlazadas a través de líneas de metro).

La calle, para los situacionistas, vuelve a cobrar protagonismo y tratarán de hacerla revivir. Como afirma Debord en su Introducción a una crítica de la geografía urbana, "el futuro pertenece a los transeúntes» (Debord 2000). Se trata de rescatar la ciudad viva y real, que sus habitantes puedan disfrutar de sus imprevistos y de los sucesos espontáneos, de volver a encontrar en la ciudad todo el azar que la racionalización y la mecanización modernas habían tratado de eliminar de ellas. La propuesta de los situacionistas consiste en proponer ciertas técnicas de paso ininterrumpido a través de ambientes diversos a través de la deriva y el détournement (desvío) (Debord 2001). 


\section{LA DERIVA COMO TÉCNICA ANTICOTIDIANA PARA EXTRAÑAR LA CIUDAD}

La deriva es una de las técnicas de desorientación capaz de provocar un extrańamiento respecto al entorno urbano cotidiano. A través de la deriva, se provoca un cambio de mirada, una percepción renovada de la ciudad que normalmente percibimos desde la rutina y a través de una recepción distraída ${ }^{3}$. Todo este pensamiento coincide con el concepto de desfamiliarización del formalista ruso Víktor Shklovski, en tanto que huye de la "trampa del hábito» ${ }^{4}$ (Sanmartín 2006). La deriva plantea una relación revolucionaria con la vida cotidiana en la ciudad contemporánea. Debord la concibe como una forma de crear itinerarios completamente nuevos e impredecibles, dependientes del azar, la casualidad del paseante (recordemos a nuestro personaje flâuneriano). La deriva se basa en la crítica a las formas rutinarias de relación con la ciudad, tanto en el ámbito del trabajo como en el tiempo libre.

Los situacionistas se pasaban días vagabundeando por la ciudad de París, en una peculiar deriva, incluso durmiendo en los sitios más insospechados. La deriva se materializaba en una "psicogeografía» definida como «el estudio de los efectos precisos del medio geográfico al actuar sobre el comportamiento afectivo de los individuos» (Foster et al. 2004). La psicogeografía haría posible la creación de mapas en los que se hubiese designado previamente qué lugares o regiones favorecían la activación de un tipo de respuesta afectiva o estética, mediante una cierta planificación (fig. 7). Así, podemos confirmar cómo la deriva se convierte en una especie de viaje onírico y una técnica efectiva para escapar de las acciones cotidianas. La deriva es, por tanto, «una técnica primordial de extrańamiento que devuelve a la rutina de lo cotidiano, el descubrimiento y la sorpresa» (Páez 2014).

\section{UNA CIUDAD PARA LA PRÁCTICA DE LA DERIVA: NEW BABYLON, DE CONSTANT}

Con motivo de la exposición Another City for another life: Constant's New Babylon durante los meses de noviembre y diciembre de 1999 en The Drawing Center en Nueva York, se publica el libro The Activist Drawing: Retracing Situationist Architectures from New Babylon to beyond (Zegher y Wigley, 2001). En éste se recogen distintas publicaciones, artículos y dibujos acerca del proyecto New Babylon, del arquitecto visionario Constant Nieuwenhuys, cuya trayectoria viene marcada por el desarrollo de una ciudad para el futuro durante casi veinte ańos de su vida.

${ }^{3}$ Respecto al concepto de recepción en la distracción, Walter Benjamin defiende en $\mathrm{La}$ obra de arte en la época de su reproductibilidad técnica (1936) un nuevo modo perceptivo presente en la modernidad (Benjamin 2005).

${ }^{4}$ El concepto de desautomatización perceptiva ha sido desarrollado ampliamente por Pau Sanmartín a través de la teoría de extrańamiento de Shklovski respecto a la creación literaria (Sanmartín 2006). 


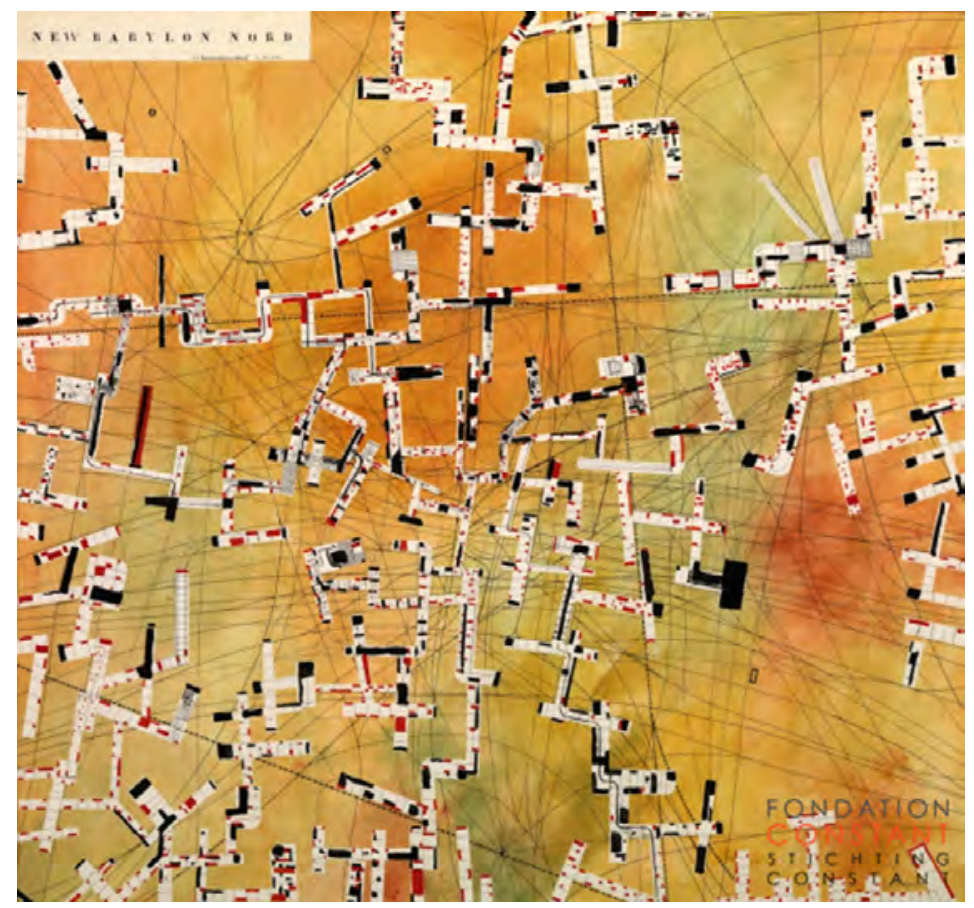

Fig. 7. Constant, New Babylon Nord, 1958, $100 \times 106 \mathrm{~cm}$, Collection Kunstmuseum Den Haag, NL.

Representante del contexto situacionista y exponente de las ideas acerca del Urbanismo Unitario y sus postulados acerca del futuro papel del arte en una sociedad tecnocrática avanzada. Con New Babylon se plantean preguntas que en la actualidad mantienen su vigencia, concernientes a la relación entre ambientes urbanos automatizados y la creatividad humana. Se cuestiona el papel de la cultura en la era de la sociedad de consumo.

\section{VIVIR JUGANDO}

Al mismo tiempo, los situacionistas también estaban muy influenciados por la lectura de Hommo ludens, de Huizinga, por el que concluyen que se debe contribuir a la recuperación de la experiencia lúdica, perdida en una sociedad tecnocrática y banalizada por el utilitarismo y el consumo. Como se deduce de sus recomendaciones «el elemento competitivo tendrá que desaparecer para dejar paso a una concepción realmente colectiva del juego: la creación en común de ambientes lúdicos elegidos» (Huizinga 1958). La separación crucial que defienden los situacionistas entre la vida corriente y el juego se deduce de los textos de Huizinga. El hombre 
debe entender el juego como parte integrante de su vida y no como una excepción aislada y temporal. Escribe Huizinga en la Internationale Situationniste n. ${ }^{\circ} 1$, de 1958: «En medio de la imperfección del mundo y la confusión de la vida, el juego realiza una perfección temporal y limitada». Así, la interpretación que los situacionistas hacen del juego es que éste debe formar parte de la vida, sin tener en cuenta su lado competitivo, a menos que su objetivo sea la «lucha por una vida a la medida de los deseos, representación concreta de esa vida» (Huizinga 1958).

La repetición será el fundamento del juego y será clave no sólo como experiencia estética, sino como manera de ordenar la propia existencia. En este sentido, Constant contrapone al espacio estático de la sociedad el espacio dinámico que nos conducirá hacia una sociedad lúdica, en contraposición a la sociedad utilitarista basada en la estaticidad, eficiencia, producción y trabajo. En cambio, la sociedad lúdica se basaría en la dinamización del espacio, donde el espacio del trabajo se convierte en terreno cambiante y a su vez objeto de juego, aventura y exploración. La desorientación dinamiza el uso del tiempo y el espacio favoreciendo una forma de vida lúdica y creativa. El espacio social de la sociedad lúdica tenía que ser, según Constant, laberíntico y al mismo tiempo continuamente modificable (Constant 2001).

\section{LA TECNOLOGÍA}

Otro de los conceptos que adquiere una gran importancia en el manifiesto de Constant acerca de la creación de una nueva ciudad es el uso de la tecnología para poder hacer realidad los objetivos propuestos. El funcionamiento de la ciudad de New Babylon viene garantizado por las tecnologías 5 . El origen de la influencia de las nuevas tecnologías se remonta al último tercio del siglo xIX, cuando la identidad ciudad-tecnología fue trasladada a los discursos artísticos, filosóficos y arquitectónicos. La visión tecnológica que floreció en la década de los sesenta era heredera de la ciudad-máquina de la modernidad (se identifica forma tecnológica como forma urbana), cuyos representantes fueron Le Corbusier y Ludwig Hilberseimer con la «ciudad-máquina». Su referencia no era ya la tecnología industrial, sino la tecnología espacial, cuyo espectacular desarrollo culmina en esa época con la llegada del hombre a la luna en 1969. El proyecto de New Babylon forma parte de un conjunto de propuestas radicales, transgresoras para el diseño de ciudades del futuro. Las nuevas ciudades propuestas se desarrollan gracias a las nuevas tecnologías. Existe en estos ańos una confianza excesiva en los logros de ésta. Todo el funcionamiento de

5 Del 21 octubre 2015 al 29 febrero de 2016 el Museo Reina Sofía reúne en la exposición Constant, Nueva Babilonia alrededor de 150 obras y abundante material documental donde se pretende difundir el proyecto del artista como «obra de arte» en el contexto social en el que se concibió. De aquí que se complementen los dibujos, collages, maquetas, pinturas y grabados con una serie de reconstrucciones, fragmentos de películas históricas y materiales de archivo. Para ampliar información consultar catálogo (Gielen et al. 2015). 


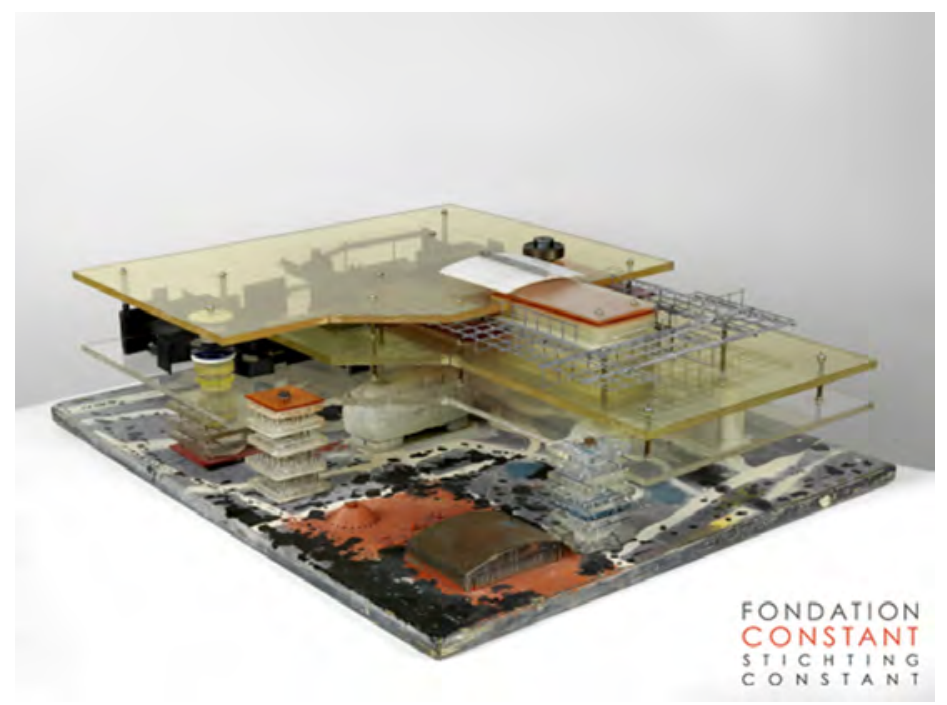

Fig. 8. Constant, Rode Sector, 1958, $27 \times 96 \times 77 \mathrm{~cm}$, Collection Kunstmuseum Den Haag, NL.

la ciudad de Constant se lo debe al uso de materiales ligeros, al control climático en el interior de la ciudad (fig. 8).

La ciudad no tiene límites, fronteras ni barreras. La tierra se cubrirá de sectores de ciudad interconectados. Los sectores son estructuras de grandes dimensiones elevadas sobre pilares. En total propone cinco sectores, laberintos tridimensionales y edificios esféricos. ¿Qué ocurre en la ciudad? La vida en el interior de los sectores liberará al hombre de su rutina. Le proporcionará el escenario para la creación de nuevas situaciones diarias, cambiantes gracias al control tecnológico. El espacio es como un gran escenario donde el propio habitante controla su escenografía; como afirma Constant en Otra ciudad para otra vida (1959): «... todo está en constante cambio. Los elementos móviles construidos y el equipamiento técnico para el clima y la manipulación de luz garantizan las variantes en todo el espacio de vida» (Constant 2001). En definitiva, se trata de buscar otras formas de conocimiento sobre nuestro entorno cotidiano por medio de actividades experimentales y vivencias concretas en los distintos lugares que pueden conformar un espacio urbano. Protagonistas de esta época fueron el Grupo Archigram, constituido en 1960, cuyo discurso se sustentaba en la suposición de que las nuevas tecnologías modificarían la esencia misma de la ciudad, y reemplazarían sus formas estables y tectónicas por conglomerados de módulos intercambiables, desechables y reproducibles, como si de artículos de consumo se tratara. Siguiendo esta premisa, Archigram proyectaba las ciudades como agregados de viviendas-cápsula enchufables a megaestructuras centrales, ensamblajes tecnológicos cuyas referencias provenían de las naves espa- 


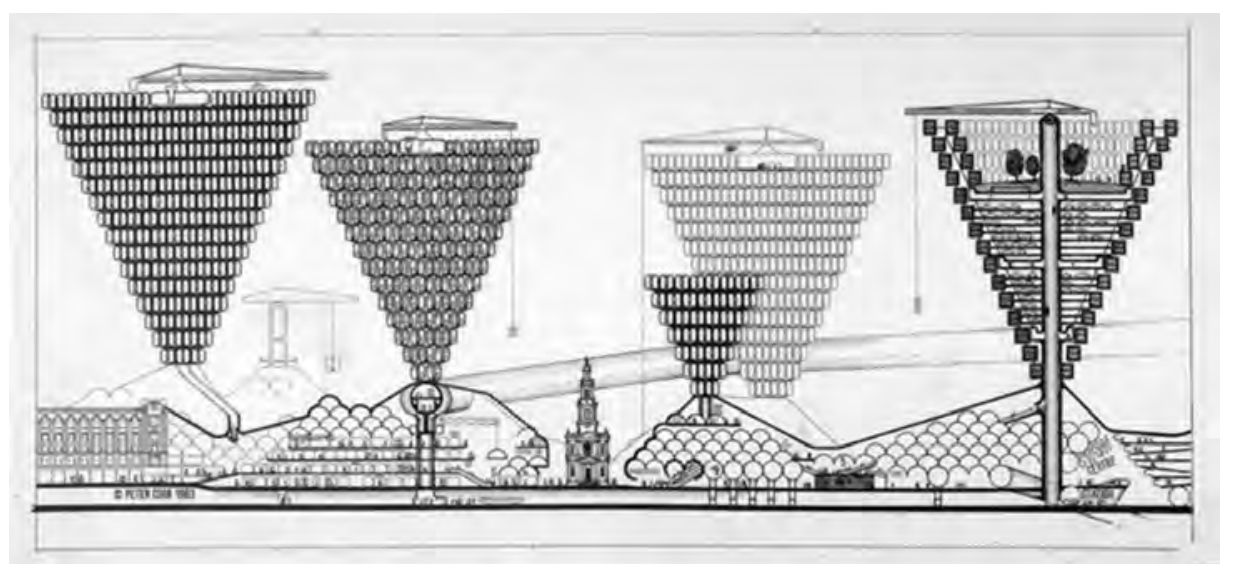

Fig. 9. Peter Cook, Plug-in City, 1963, 12,7 ×60 cm, Archigram Archives.

ciales imaginadas por la literatura de ciencia ficción. La Plug-in City de Peter Cook (1964) y las Walking Cities de Ron Herron (1964) son algunos de los ejemplos de estas fantasías futuristas (fig. 9). Con la propuesta de Constant para New Babylon se recupera la idea del juego, la movilidad y la transitoriedad, así como la aceptación de la tecnología como instrumento para alcanzar esa otra vida. Con New Babylon, Constant propone una "ciudad cubierta" a partir del diseńo de una construcción espacial continua, separada del suelo, en la que no existen calles ni tráfico en su interior, ya que se desvía por encima o por debajo de esta estructura.

\section{EL DIAGRAMA}

El diagrama es el mínimo elemento gráfico que representa una idea abstracta, un proceso, un espacio, un concepto. Los dibujos de Constant pueden ser concebidos como diagramas, como posibilidad de expresión que se acerca más al objetivo que pretende alcanzar Constant: alejarse de las formas preconcebidas y plantear un esquema libre. Un diagrama entendido como interfase entre el sujeto y la realidad. Durante los años sesenta y setenta se utilizan frecuentemente los diagramas como esquemas geométricos previos a la formalización del objeto final.

Acerca del concepto de diagrama, Bernard Tschumi, en el artículo «Operative Drawing» (Tschumi 2001), distingue cuatro categorías: diagrama conceptual, trascripción, secuencia transformacional y dibujo de escala intercambiable, los cuatro conceptos con una hipótesis común: la forma nunca es su objetivo, sino que, por el contrario, es la generación de las condiciones de uso, programas y eventos. En «Diagramas de Utopía», Anthony Vidler defiende que el diagrama es principalmente un icono de relaciones inteligentes para construir un objeto y defiende 


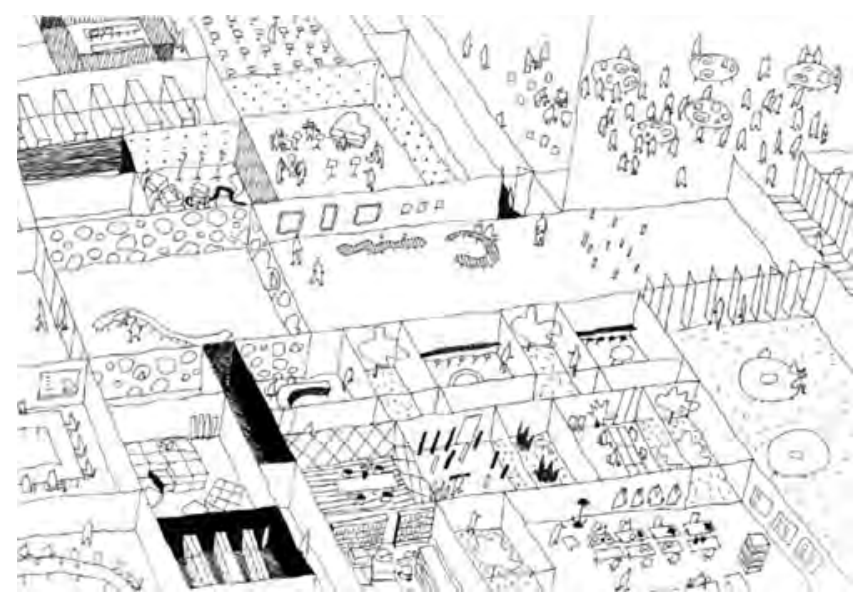

Fig. 10. Sejima K. y Nishizawa, R. (SANAA), Almere Competition Sketches, 1998, https://arcspace.com/studio/sanaa-competition-sketches/.

la tridimensionalidad de los diagramas de la ciudad utópica de Constant (Vidler 2001), Para Vidler, todas las utopías son, necesariamente diagramáticas. New Babylon corresponde pues a la lógica del diagrama. Actualmente los diagramas son ya arquitecturas en sí mismas, no representan, sino que aluden a una realidad arquitectónica. Son generadores de nuevas estructuras. Así, el dibujo se sustituye por el diagrama, como expresión de un proceso. Un ejemplo del uso del concepto de diagrama contemporáneo lo encontramos en la arquitectura de SANAA (Sejima + Nishizawa y Asociados).

El arquitecto Toyo Ito, en la revista $E l$ Croquis n..$^{\circ} 77$, publica un artículo sobre la arquitectura de Kazuyo Sejima y Ryue Nishizawa, acuñando el término de «arquitectura diagrama», en el que, según afirma «un edificio es el equivalente al diagrama del espacio que se usa para describir de forma abstracta las actividades cotidianas que se presuponen en el edificio" (Sejima 2001). Se trata de crear formas y modelos abstractos espaciales, a partir del diagrama, alejado de toda referencia histórica. En el proyecto para el Teatro Municipal de Almere (1988) se percibe ese carácter mínimo de representación a modo de sectores que pertenecen a un todo, como si se hubiese levantado en tres dimensiones directamente el diagrama, tratando de dotar de importancia al material frente a la forma. Asimismo, en algunas de las propuestas de Rem Koolhaas y Bernard Tschumi se hace patente el uso del diagrama como herramienta proyectual, los cuales no tratan de prefigurar o dar forma al edificio, sino de incorporar a estos sus cualidades (fig. 10).

En la memoria del proyecto del teatro explican:

La organización de la arquitectura deviene en una ocasión importante para sugerir tipos de interacciones y encuentros. Nos gustaría pensar en este complejo cultural 


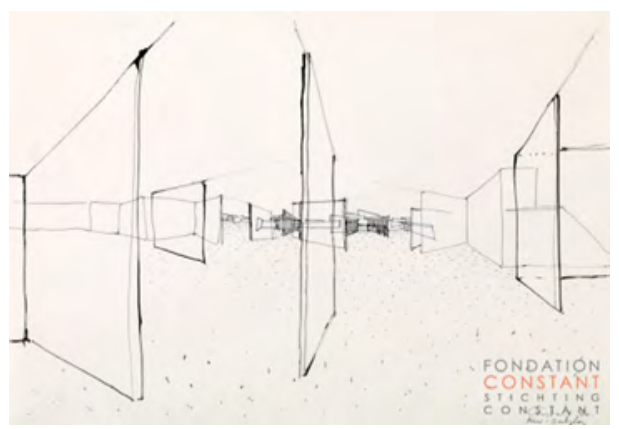

Fig. 11. Constant, Mobiele wanden, 1960, $32 \times 45 \mathrm{~cm}$, Collection Kunstmuseum Den Haag, NL.

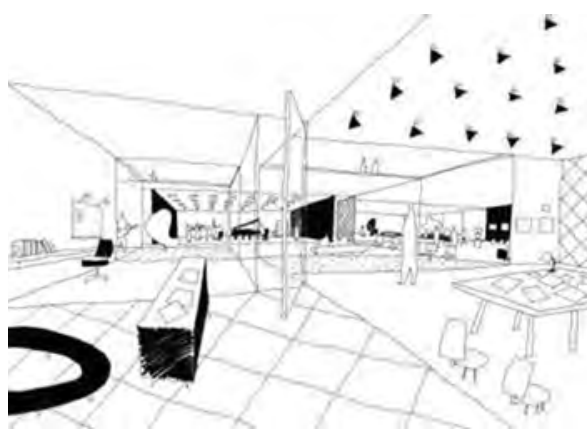

Fig. 12. Sejima K. y Nishizawa, R. (SANAA), Almere Competition Sketches, 1998.

https://arcspace.com/studio/sanaa-competition-sketches/.

como una arquitectura que pueda convertirse en una especie de parque público interior, propiciando de manera natural el intercambio de información y los encuentros de diverso tipo. [...] las divisiones se disponen según un sistema en el que paneles con propiedades diversas pueden levantarse junto a paneles estructurales, con igual énfasis. Nuestro propósito es crear una secuencia fluida de materiales diferenciados (Sejima 2001).

¿Y no son éstos precisamente los objetivos propuestos para la ciudad de $N e w$ Babylon? Para ambos autores los diagramas suponen la representación de la flexibilidad, del espacio cambiante (figs. 11 y 12).

\section{DE LA UTOPÍA URBANA A LA HIPERSENSIBILIDAD}

La aventura del extrañamiento continúa en la ciudad contemporánea. Irrumpe una nueva sensibilidad en el ámbito urbano que reivindica la complejidad de las relaciones sociales en la ciudad. Mediante experiencias de origen psicogeográfico o deriva situacionista, las propuestas del equipo de arquitectos We are an event dan muestra del reciente interés por visibilizar el entorno urbano inmediato ${ }^{6}$. Desde su práctica, buscan cuestionar los modos de hacer dentro de la disciplina arquitectónica a través del dibujo a mano alzada como herramienta de investigación formal

${ }^{6}$ We are an event es un personaje de ficción creado por los arquitectos franceses Lambert Moiroux y Quentin Laurens-Berge. Afirman que «tomar la decisión de salir a caminar es escaparse de su cotidiano. Ir a encontrarse con situaciones urbanas. Las exploraciones componen una fuente de materia primaria para generar un imaginativo de cada ciudad en las que trabajamos. El dibujo se hace caminando sobre un plano urbano. Se trata de ubicar las cosas que nos estimulan, dibujarlas, escribir también sobre ellas» (Hernández 2018). 

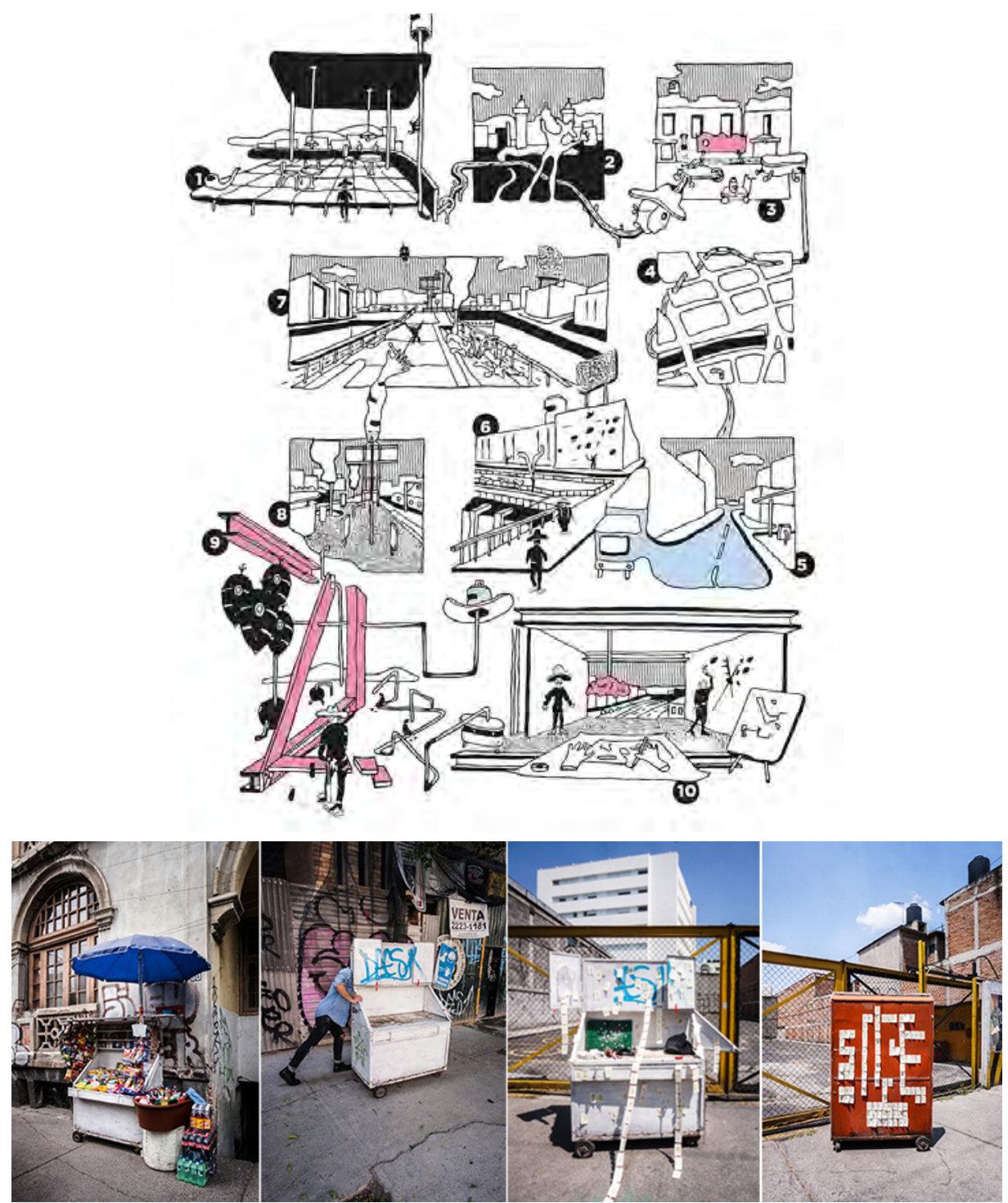

Figs. 13 y 14. We are an event, Concurso Tanquito, 2018, https://www.arquine.com/we-are-an-event/.

y teórica. Registran elementos cotidianos de la ciudad: el afilador de cuchillos en bicicleta, el vendedor de pedestales, tanques elevados, vendedores de gas y merengues, etc. Microarquitecturas precarias, nómadas o sedentarias, que están inteligentemente pensadas y que conforman la urbanidad de México (figs. 13 y 14). 


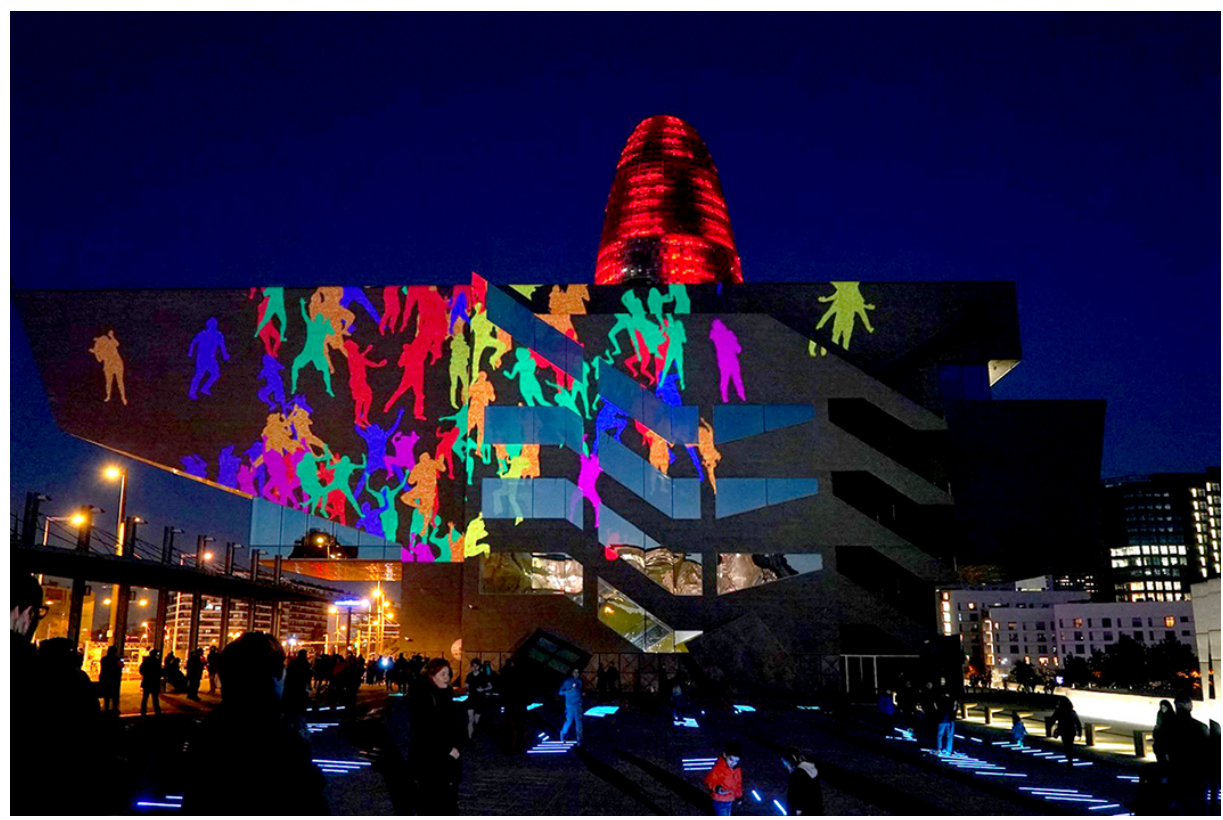

Fig. 15. Daniel Canogar, Asalto Barcelona, 2019, Videoproyección sobre el Museo de Diseño de Barcelona, http://www.danielcanogar.com/es/obra/asalto-barcelona.

Como vemos, el análisis de la cotidianeidad en el ámbito urbano ha supuesto un instrumento para investigar fenómenos urbanos emergentes y, por extensión, construir una práctica de teoría de la arquitectura basada en una interrogación de la vida cotidiana. No hay grandes acontecimientos en lo cotidiano, sino pequeñas acciones que son normadas, relatadas y cotidianizadas.

Otro de los ejemplos de provocar la interacción entre la ciudad y sus habitantes lo encontramos en las obras del artista Daniel Canogar. Sus obras nacen del deseo de que los ciudadanos se proyecten, literal y metafóricamente, sobre su entorno inmediato, y sus herramientas son el cuerpo y la tecnología (fig. 15).

En Daniel Canogar, el interés por desarrollar una estrategia artística que se base en la interacción entre la sociedad (el público participante y las relaciones que se generan entre ellos), el entorno (la arquitectura donde se manifiesta la obra) y la tecnología (los instrumentos que conectan a la arquitectura con la interacción de los participantes) se manifiesta sobre todo en la serie de los Asaltos, videoproyecciones con participación pública que hacen reaccionar a éste. Los Asaltos son el resultado de performances participativas y colaborativas que involucran a las personas, en tanto espectadores/participantes, en la metáfora «de obstáculos sociales, políticos y personales» que podemos encontrar en nuestra vida (Ansorena 2014). 
El artista crea una situación donde el edificio, el contexto urbano y los participantes se relacionan de una nueva manera. Se trataría, por tanto, de una obra relacional ${ }^{7}$, ya que se crean relaciones o conexiones entre los participantes y su entorno. Asalto Barcelona (2019) es una videoproyección sobre el Museo de Diseño de Barcelona (DHUB), una obra de arte relacional, un evento que rompe los límites entre el espectador y el edificio. El autor afirma que

... estas obras invitan al espectador a observar la obra desde múltiples perspectivas, así, su movimiento se convierte en un componente crucial de la experiencia de la pieza. Ser un espectador a menudo significa permanecer al margen de lo que estamos viendo, por lo tanto, a través de mi obra quiero que el espectador se comprometa con las piezas de forma activa (Canogar 2019).

A través de un proceso artístico basado en las propuestas de nuevas relaciones con la sociedad, el entorno y las nuevas tecnologías, Daniel Canogar intenta manifestar una manera abierta y libre de una producción artística que implica la participación directa de los ciudadanos, como reflejo de nuestra cultura y nuestra época, centrándose más en la actitud que orienta los procesos de socialización colectiva que en la forma que caracteriza un objeto individual.

\section{LO «EXTRAÑO» VIGENTE EN LAS REFLEXIONES SOCIOLÓGICAS CONTEMPORÁNEAS}

Zygmunt Bauman ha tratado la temática de lo extraño dentro del contexto de la modernidad, desarrollando un amplio cuerpo teórico bajo el enfoque de la fluidez como seña de identidad en el mundo moderno y sus procesos, concentrando sus análisis en la ambivalencia inherente a su desarrollo (Bauman 2003). Los movimientos que originan cambios y al mismo tiempo conservación son los que, en realidad, configuran la ambivalencia en la contemporaneidad. La concepción más reciente de Bauman sobre la modernidad, condensada en el concepto de modernidad líquida, evidencia algunas características singulares de nuestro tiempo: la permeabilidad, el movimiento irregular, la falta y, al mismo tiempo, la necesidad de solidez. Para Bauman, extraño es aquel individuo que incorpora toda esta ambivalencia.

Los extraños de la contemporaneidad continúan representando la resistencia a la fijación y la contestación de las oposiciones, cuestionando la modernidad como un seguro campo de acción. Pero Bauman atribuye la no especificidad del

7 Nicolás Bourriaud hace referencia a la arquitectura / arte relacional, pensando en una estrecha relación entre público, entorno y nuevas tecnologías utilizadas por la creación, afirma así: «Las obras ya no tienen como meta formar realidades imaginarias o utópicas, sino constituir modos de existencia o modelos de acción dentro de lo real ya existente, cualquiera que fuera la escala elegida por el artista... La modernidad se prolonga hoy en la práctica del bricolaje y del reciclaje de lo cultural, en la invención de lo cotidiano y en la organización del tiempo» (Bourriaud 2008). 
extraño a la posibilidad de aprender a lidiar con los movimientos contradictorios de la modernidad. La existencia de lo extraño, como señala Bauman, nos muestra que las cosas podrían ser diferentes, no en un sentido negativo, sino en el sentido de que existen posibilidades dispuestas a ser exploradas, que pueden, o no, conducir a una convivencia más tolerante en un contexto el del mundo contemporáneo, caracterizado por la inmediatez, fugacidad e hiperinformación.

\section{CONCLUSIONES}

Hemos tratado de esbozar un breve recorrido por las transformaciones perceptivas de los habitantes de nuestras ciudades en constante cambio, desde la perspectiva del extrańamiento, como técnica o efecto que trata de detener y modificar nuestra percepción habitual, a través de la ruptura, el asombro y el shock emocional. En el ámbito urbano, resulta claro que la experiencia del reconocimiento urbano comienza con el personaje del flâneur baudeleriano que se sitúa en términos de descubrimiento o encuentro casual y que luego desarrollaran los situacionistas ampliamente. Mediante técnicas como la deriva situacionista se propone una reflexión sobre las formas de experimentar la vida urbana, para escapar de la vida rutinaria y buscar nuevas emociones en busca de situaciones radicales. El extrañamiento implica un estado de alerta en el receptor, un sentido de la percepción no pasivo, que moviliza o altera las condiciones esperadas. Hemos visto en el caso de las técnicas de derivas urbanas cómo procesos diagramáticos son puestos en marcha como maneras activas de exploración urbana y en otros casos el extrañamiento ha sido generado gracias a tecnologías casi invisibles que no tratan de definir objetos arquitectónicos, lo que implica una disolución de los límites, de la imagen e incluso del propio edificio.

La extrañeza enfocada desde el ámbito del cine nos ofrece personajes flaunerianos como Mr. Hulot, que cuestiona nuestras relaciones con la arquitectura y la ciudad, y su capacidad para relacionarnos con ella, haciéndonos capaces de remirar bajo otro prisma, convertir lo cotidiano en algo sugerente. Mr. Hulot, el espectador y la cámara permanecen distanciados, y es desde esa distancia, en ese desplazamiento, donde comenzamos a comprender.

Finalmente, obras como Asaltos, de Daniel Canogar, una suerte de espectáculos de videoimágenes sobre el contexto urbano, ponen de manifiesto la necesidad de la implicación del espectador activo, que, a diferencia de aquel espectador que asistía a oscuras sesiones llamadas fantasmagorías, de Etienne Gaspard Robertson, en el siglo XVIII, se apropia de la ciudad y la asalta. El sujeto contemporáneo, aturdido, sorprendido y saturado de información, debe contextualizar esta dimensión urbana del mundo para poder comprender mejor las consecuencias sociales y culturales de la fantasmagoría contemporánea en la que nos hallamos inmersos. 


\section{BIBLIOGRAFÍA}

Ansorena, J. (2014). Daniel Canogar asalta Times Square [Internet]. [cited 2019 Noviembre 11]. Disponible en https://www.abc.es/cultura/arte/20140819/abci-daniel-canogar-timessquare-201408182047.html.

Bauman, Z. (2003). Modernidad líquida. Traducción de Rosenberg, M. en colaboración con Arrambide, J. Buenos Aires: Fondo de Cultura Económica. 231 pp.

Benjamin, W. (2005). Libro de los pasajes. Madrid: Akal Ediciones. 1102 pp.

Benjamin, W. (2008). La obra de arte en la época de su reproductibilidad técnica. Obras. Libro i, vol. 2. Madrid: Abada. 370 pp.

Bourriaud, N. (2008). Estética relacional. Buenos Aires: Adriana Hidalgo Editora. 143 pp.

Buchloh, B., Bois, Y.A., Foster, H. y Krauss, R. (2004). Arte desde 1900: modernidad, antimodernidad, posmodernidad. Madrid: Akal. 704 pp.

Camus, A. (2012). El extranjero. Madrid: Difusora Larousse-Alianza Editorial. 128 pp.

Canogar, D. (2019). Extracto de la memoria de sus obras [Internet] [cited 2020 Feb 10]. Available from http://www.danielcanogar.com/es/manifiesto.

Constant, N. (2001). Una ciudad para otra vida, Internacional Situacionista. Textos completos en castellano de la revista Internationale Situationniste (1958-1969), vol. 1. La realización del arte. Madrid: Literatura gris, pp. 96-98.

Crary, J. (2008). Suspensiones de la percepción: atención, espectáculo y cultura moderna. Madrid: Akal. 368 pp.

Debord, G. (2000). «Introducción a una crítica de la geografía urbana». A Parte Rei, n. ${ }^{\circ}$ 11; [cited 2020 Feb 10]. Available from http://serbal.pntic.mec.es/-cmunoz11/debord3.pdf.

Debord, G. (2001). Hacia una internacional situacionista, Internacional Situacionista. Textos completos en castellano de la revista Internationale Situationniste (1958-1969), vol. 1. La realización del arte. Madrid: Literatura gris, pp. 215-217.

Freud, S. (1988). «Lo siniestro», en Freud. Obras completas, vol. 7: ensayos XCVIII-CXII. Barcelona: Ediciones Orbis. pp. 1856-1939.

Gielen, P., Horst, T., Koolhaas, R., Constant, N., Romero, P.G., Stamps, L., Vaan der Stokvis, W. y Wigley, M. (2015). Constant: Nueva Babilonia. Madrid: Museo Nacional Centro de Arte Reina Sofía [Cat. Exp.]. 318 pp.

Hernández, P. (2018). El papel de la ficción en la arquitectura. Conversación con We are an event [Internet]. En Portal Web Oficial de la revista Arquine [cited 2018 Ago 20]. Available in https://www.arquine.com/we-are-an-event/.

Huizinga, J. (2007). Homo Ludens (1. ed. 1972). Madrid: Alianza/Emecé. 286 pp.

Le Corbusier (1967). The Radiant city: Elements of a Doctrine of Urbanism to be used as the Basis of Our Machine-age Civilization. New York: Orion Press. 197 pp.

Lefebvre, H. (1984). La vida cotidiana en el mundo moderno. Madrid: Alianza Editorial. 247 pp.

Martínez, I. (1998). «Anomía, extrañamiento y desarraigo en la literatura del siglo xx: un análisis sociológico». Revista Española De Investigaciones Sociológicas. 84. pp. 223-242. 
Ockman, J. (2011). Arquitectura en modo de distracción: ocho tomas sobre Playtime de Jacques Tati. [Internet] DC PAPERS. 22: 11-34. Available From http://dialnet.unirioja.es/servlet/ oaiart? codigo $=3910806$.

PÁEz, B.R. (April 1, 2014). «Derivas urbanas: la ciudad extrañada». Rita, 1, pp. 120-129.

SAn Nicolás, J.H. (2015). Jaques Tati: Vivienda experimental y espacios de trabajo a mediados del siglo $X X$ [tesis doctoral]. ETS Arquitectura. Universidad Politécnica de Madrid. 513 pp.

Sanmartín Ortí, P. (2006). La finalidad poética en el formalismo ruso: el concepto de desautomatización [tesis doctoral]. Universidad Complutense de Madrid. 581 pp.

Sejima, K. y Nishizawa, R. (2001). «Kazuyo Sejima 1983-2000 + Ryue Nishizawa 1995-2000: Making the boundary». El Croquis, n. ${ }^{\circ}$ 99. pp. 6-20.

Simmel, G. (2001). «El individuo y la libertad. Ensayos de crítica de la cultura. Las grandes urbes y la vida del espíritu». Revista De Estudios Sociales, 10, pp. 107-109.

Tschumi, B. (2001). «Operative Drawing», en De Zegher, C., Wigley, M., editores. The Activist Drawing: Retracing Situationist Architectures from Constant's New Babylon to Beyond. Nueva York: MIT Press. pp. 135-137.

Vidler, A. (2001). «Diagrams of Utopia», en De Zegher, C., Wigley, M., editores. The Activist Drawing: Retracing Situationist Architectures from Constant's New Babylon to Beyond. Nueva York: MIT Press. pp. 84-86.

Wigley, M. y Zegher, M.C. (2001). The activist drawing: Retracing situationist architectures from Constant's New Babylon to beyond. New York; Cambridge, Mass.: Drawing Center; MIT Press. 152 pp. 



\title{
LA IGLESIA PALENTINA DE SAN PABLO: BREVE ESTUDIO SOBRE SUS RETABLOS (SIGLOS XV-XVII)
}

\author{
Ester Prieto Ustio* \\ Universidad de Sevilla \\ esterprieto@hotmail.com
}

\section{RESUMEN}

La iglesia palentina de San Pablo, situada en el centro neurálgico de la ciudad castellana, es un magnífico ejemplo para analizar la evolución artística desde el siglo XIII hasta el XVIII. Con el presente artículo, queremos llevar a cabo un breve estudio acerca de cinco de los retablos y enterramientos que forman o formaron parte del templo dominico, realizados entre los siglos XV y XVII, para comprobar la importancia que tuvo este espacio en la recepción de las principales tendencias artísticas europeas desarrolladas a finales de la Edad Media y comienzo de la Edad Moderna.

Palabras Clave: retablo, sepulcro, escultura, pintura, iglesia de San Pablo, Palencia.

\section{THE PALENCIA CHURCH OF SAN PABLO: \\ BRIEF STUDY ON ITS ALTARPIECES (15TH-17TH CENTURIES)}

\section{Abstract}

The church of San Pablo, located in the center of Palencia is a magnificent example to analyze artistic evolution from the $13^{\text {th }}$ to the $18^{\text {th }}$ centuries. With this article, we want to carry out a brief study about five of the altarpieces and tombs that form or were part of the Dominican temple, realized between the $15^{\text {th }}$ and $17^{\text {th }}$ centuries, to verify the importance of this space in the reception of the main European artistic trends developed at the end of the Middle Ages and the beginning of the Modern Age.

Keywords: altarpiece, tomb, sculpture, painting, San Pablo church, Palencia. 


\section{INTRODUCCIÓN}

La iglesia de San Pablo, ubicada en el corazón de Palencia, es desde sus orígenes la sede de la comunidad dominica en la ciudad castellana, la cual habita en un convento anexo al templo. Declarada Monumento Histórico-Artístico Nacional en $1931^{1}$, en el interior de sus pétreos muros custodia una destacada colección de pinturas, esculturas y artes decorativas realizadas entre los siglos XIII y xx (Pérez 1995).

Cabe señalar su papel en la historia, ya que durante la Edad Media fue sede de las Cortes Generales de Castilla en varias ocasiones y también acogió diversos Capítulos Generales de la Orden de Predicadores (Domínguez 2017).

El primitivo espacio monacal fue fundado entre 1219 y 1220 por el propio santo Domingo de Guzmán, siendo el segundo convento personalmente instaurado por el religioso (Medrano 1725). Esto fue debido a su vinculación personal con la ciudad, ya que el burgalés realizó su formación académica en el Studium Generale de Palencia, considerado como la primera universidad establecida en la Península Ibérica y una de las primeras del continente europeo, junto con París y Bolonia. Aunque la creación del centro de enseñanza se fecha entre 1208 y 1212 gracias a la iniciativa del ilustre obispo Tello Téllez de Meneses, se tiene constancia de su funcionamiento con anterioridad (Fuente 2012).

Actualmente, no queda ningún vestigio del antiguo convento, ya que fue ocupado como cuartel -al igual que la iglesia- por el ejército francés durante la Guerra de la Independencia y desamortizado en 1835 . Once ańos más tarde los dominicos volvieron a su sede, pero las dependencias conventuales fueron derruidas y durante las primeras décadas del siglo xx se erigió un nuevo edificio que sirviera de residencia para los religiosos (Quadrado 1865).

\section{EL TEMPLO}

La iglesia, en sus orígenes románica, sufre una completa remodelación entre los siglos XIV y XVI, siguiendo las directrices estilísticas del gótico tardío. Toda ella fue realizada con piedra de cantería muy bien trabajada, y se estableció un esquema de planta de tres naves, siendo la central más ancha y cubierta por bóvedas de crucería con combados y terceletes, mientras que en las laterales se aplicaron bóvedas de crucería simple. Sobre la nave de la epístola, se adosaron seis capillas laterales, mientras que en la nave del evangelio se conservan algunos restos del claustro gótico que estaba anexo al templo, así como la portada que permitía su acceso (Navarro 1946).

El exterior se presenta sencillo y austero, sin apenas decoración. Cuenta con dos puertas de entrada; la principal, situada a los pies de la parroquia, se fecha a finales del siglo XVIII con un carácter ya neoclásico y todavía un influjo escuria-

\footnotetext{
* Investigadora predoctoral. Universidad de Sevilla.

${ }^{1}$ Catálogo de Bienes Protegidos de la Junta de Castilla y León.
} 


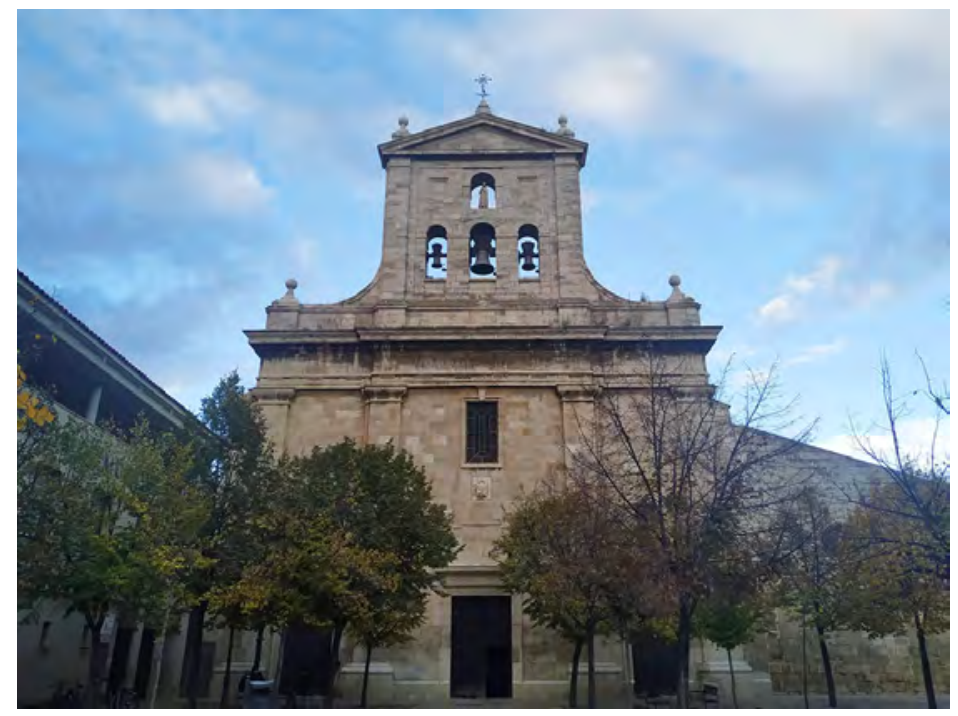

Fig. 1. Manuel Turrillo, iglesia de San Pablo (Palencia), fachada principal, finales del siglo XviIr. Fotografía: Ester Prieto Ustio.

lense. Formada por dos cuerpos, el inferior es una mole rectangular con tres puertas adinteladas, delimitadas por pilastras de orden toscano que ocupan toda la superficie. La parte superior se compone por una gran espadaña de líneas muy depuradas con cuatro hornacinas, una de ellas acoge una escultura de la Virgen de Fátima y las tres restantes contienen campanas. Se remata con un frontón triangular y dos aletones laterales decorados con bolas. El proyecto de remodelación de esta fachada, presentado por el arquitecto Manuel Turrillo, fue aprobado por la Comisión de Arquitectura de la Real Academia de Bellas Artes en 1787 (Saiz y Sánchez 2017)² (fig. 1).

Unos años antes de esta fecha, entre 1770 y 1771, se fecha el Estado general de las cofradias y hermandades de la ciudad de Palencia ${ }^{3}$, documento en el cual se recogen las cuatro agrupaciones asentadas en el convento de San Pablo, así como datos relativos a las mismas.

La cofradía Jesús Nazareno contaba con 80 hermanos en ese momento, llevaba a cabo una celebración anual y sus rentas eran de 1220 reales, mientras que sus gastos sumaban un total de 1114 reales.

2 El documento aparece compilado en Juntas de la Comisión de Arquitectura de 15 de octubre y 13 de diciembre de 1787, ARABASF, libro 3-139, fols. fol. 74 y 79. Referencia documental recogida en el artículo mencionado en el texto.

${ }^{3}$ Archivo Histórico Nacional, Consejos, 7097, Exp. 20, N. 1. 


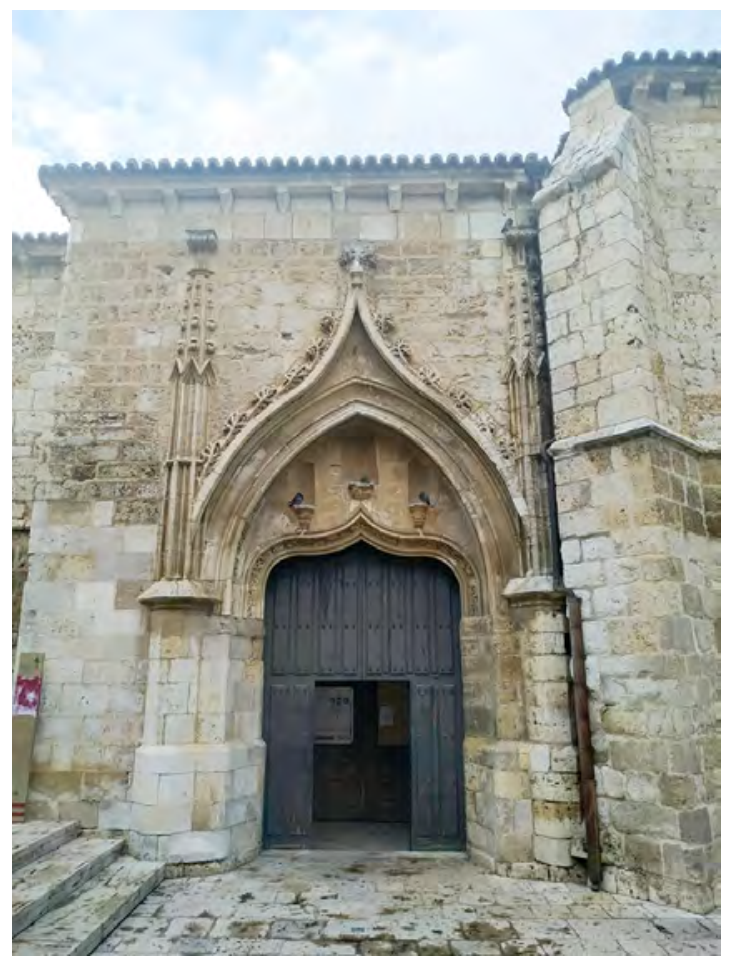

Fig. 2. Anónimo, iglesia de San Pablo (Palencia), fachada lateral, finales del siglo Xv-comienzos del Xvi. Fotografía: Ester Prieto Ustio.

La cofradía de la Santa Vera Cruz, con 1000 cofrades inscritos, constituía la segunda más popular en cuanto a miembros de la ciudad, por detrás de la de San Antonio Abad. Con un total de tres fiestas al año, sumaba 2653 reales de rentas y 2634 reales de gastos.

600 individuos formaban parte de la cofradía de Nuestra Señora del Rosario, la cual poseía 2672 reales en rentas, sus gastos ascendían a 3346 reales y celebraba una única fiesta anual.

La última cofradía con sede en el recinto dominico era la de las Ánimas del Camposanto de San Juan de Dios, cuyas rentas y gastos sumaban la misma cantidad, 2070 reales. Sus 380 cofrades organizaban una fiesta al ańo.

Volviendo al exterior del conjunto, su otra portada, abierta hacia el lado de la epístola, se llevó a cabo a finales del siglo Xv y comienzos del xvi. Consta de una combinación de arcos apuntados y conopiales, con decoración antropomórfica y vegetal entre sus arquivoltas, con todo el conjunto enmarcado entre pináculos laterales al modo de columnas, muy en consonancia con el dominado gótico isabelino o estilo Reyes Católicos (Martínez 1989) (fig. 2). 
Una de las grandes joyas de San Pablo es su capilla mayor. Realizada en sólida piedra con planta cuadrada, su parte exterior tiene un cierto carácter defensivo, contrastando con el interior, decorado con destacados ejemplos del arte renacentista espańol. El cubrimiento se lleva a cabo con una gran bóveda estrellada y combada, la cual acoge un destacado retablo plateresco. En los laterales de la capilla, se ubican los sepulcros de los I y iII marqueses de Poza, importantes benefactores tanto del templo como del convento. Estas tres obras conjugan los materiales más característicos del Renacimiento como la madera -retablo mayor-, la piedra-el sepulcro de los I marqueses de Poza-y el mármol -el nicho funerario de los III marqueses-, los cuales veremos con más detalle a lo largo de estas páginas.

En el presbiterio también se sitúa la sillería de coro, la cual originalmente se encontraba en el coro alto - a los pies de la iglesia-, pero tras reformas litúrgicas se traslada a la capilla mayor. Tallada en madera de nogal y ejecutada a finales del siglo XV y comienzos de la centuria posterior, cuenta con decoraciones vegetales y geométricas. Aparece en varias ocasiones el escudo de la familia Mendoza, y es que uno de sus más célebres miembros, Diego Hurtado de Mendoza, fue obispo de la Diócesis palentina entre 1471 y 1485 (García y Alonso 1981).

\section{BREVE CONTEXTO CULTURAL, PALENCIA: SIGLOS XV-XVII}

Desde finales del siglo XV y hasta comienzos del XVII, las ciudades castellanas de Palencia, Burgos y Valladolid vivieron un verdadero florecimiento económico gracias al comercio textil -especialmente del lanar-con Flandes, otros puntos de la Península e incluso América (Casado 2018), lo que ayudó a desarrollar grandes empresas artísticas en el ámbito civil, con la construcción de nuevas moradas para sus acaudalados propietarios, oratorios para la devoción particular, así como capillas de carácter funerario para funcionar como panteones familiares en los templos, y también en el ámbito religioso, ya que muchas órdenes religiosas ya asentadas en estas urbes emprendieron reformas en sus iglesias y conventos o incorporaron obras de arte adaptadas a las nuevas propuestas estéticas, de igual modo que hicieron los cabildos catedralicios.

Este auge monetario dio la posibilidad del establecimiento, ya desde el reinado de los Reyes Católicos, de una serie de artistas procedentes principalmente de las zonas flamencas, francesas y alemanas, como es el caso de Felipe Vigarny (Del Río 2000) y Juan de Juni (Fernández 2012), los cuales causaron una notabilísima influencia en artífices locales, al igual que la llegada de los modelos italianos a través de estampas, grabados y las estancias en tierras transalpinas de los castellanos Alonso Berruguete (Hoyos 2013) y Diego de Siloé (Gómez-Moreno 1963), quienes pudieron conocer de primera mano las ideas artísticas planteadas en la Italia del Cinquecento.

Palencia se convirtió en receptora de las tendencias propuestas en las escuelas burgalesa y vallisoletana, contando con la participación de los artistas más destacados de cada una de ellas en obras de la capital y los alrededores, pero también existieron dos talleres propiamente palentinos, el de Juan Ortiz el Viejo, discípulo 
de Vigarny y cuyo hijo, Luis Ortiz, será su sucesor al timón del obrador, y el de Juan de Valmaseda, ambos escultores muy activos en la primera mitad del siglo Xvi en la zona del Camino de Santiago palentino y la Tierra de Campos, como se puede observar en Población de Campos, Requena de Campos, Frómista o Carrión de los Condes, en cuyas iglesias se custodian piezas gubiadas por estos talleres (Portela 1977). También fue cuna de dos de los artistas más destacados del panorama renacentista español, Alonso y Pedro Berruguete, ambos nacidos en Paredes de Nava.

\section{LOS RETABLOS DE LA IGLESIA DE SAN PABLO: SIGLOS XV-XVII}

El templo palentino acoge entre sus muros una gran variedad retablística, pero vamos a centrar nuestro trabajo en el análisis de los retablos de Santa Úrsula, de la Piedad, retablo mayor y los sepulcros-retablos de los marqueses de Poza, en los que observaremos la evolución artística desde la pintura del gótico internacional hasta la escultura renacentista de influjos escurialenses.

\section{RETABLO DE SANTA ÚRSULA}

El que fuera el retablo dedicado a santa Úrsula y las once mil vírgenes, se conserva actualmente desmembrado y repartido por diversas partes del mundo. Según la historiografía (Pérez y Rodríguez 1995; Post 2014), en una fotografía ${ }^{4}$ realizada en el interior del convento de San Pablo en torno a 1879, posiblemente por Jean Laurent o algún artista de su entorno, se observaba un retablo barroco conformado por una escultura de san Pío V y una serie de paneles de clara factura gótica, los cuales fueron identificados como los procedentes de este malogrado conjunto al que nos vamos a referir, el cual estaría constituido en dos cuerpos con ocho tablas, una predela con siete compartimentos y cinco calles; en la central podría haberse ubicado una representación individual de la santa, según la reconstrucción realizada por Fernando Pérez y María Victoria Rodríguez (Pérez y Rodríguez 1995). Por su parte, Joaquín Yarza ha sugerido que, siguiendo las tendencias escultóricas del

${ }^{4}$ Dicha fotografía, según las investigaciones de Pérez y Rodríguez, 1995 y Post, 2014, forma parte del Archivo Ruiz Vernacci, compuesto por un numerosísimo conjunto de soportes fotográficos realizados entre 1858 y 1960, aglutinando producciones de fotógrafos como Jean Laurent, Catalina Melina Dosch, Alfonso Roswag, Joseph Jean Marie Lacoste Borde, Ángel Redondo de Zúńiga, Juana Roig Villalonga y el propio Joaquín Ruiz Vernacci. Este archivo fue adquirido en 1975 por el Estado español, y en la actualidad se encuentra integrado en la Fototeca del Instituto del Patrimonio Cultural de Espańa. Hemos consultado dichos fondos durante el mes de enero de 2020, pero no hemos encontrado la fotografía mencionada tanto por Pérez y Rodríguez como por Post, por lo que no podemos corroborar esta hipótesis. 
momento, es posible que una Crucifixión hubiese constituido el remate del ático (VV. AA. 1993).

Se ha mencionado que en 1909, las cuatro tablas inferiores del conjunto retablístico 5 se encontraban en manos de sir Francis Beaufort Palmer, experto británico en leyes y miembro del Burlington Fine Arts Club, aunque se desconoce cómo llegaron a formar parte de su colección. Diez años más tarde, las piezas salieron a subasta en la sede londinense de Christie's como el lote número 6, siendo adquiridas por la compañía Gooden \& Fox -posteriormente conocida como Hazlitt, Gooden \& Fox Ltd.-, conformada por los marchantes y asesores artísticos S.T. Gooden y F.W. Fox, para William Hesketh Lever, por un precio de 624 libras $^{6}$.

Antes de que Lever, vizconde de Leverhulme, quien compaginó su labor empresarial y política con la filantropía y el coleccionismo artístico, las incluyera en The Lady Lever Art Gallery -museo que fundó en 1922 en honor de su esposa Elizabeth, ubicado en Port Sunlight, Liverpool-, estas tablas fueron mostradas en exposiciones como la Spanish Old Masters, celebrada entre 1913 y 1914 en las galerías Graffton ${ }^{7}$ y en la Exhibition of Spanish Paintings, la cual se pudo visitar entre 1920 y 1921 en la Royal Academy of London ${ }^{8}$.

Las tablas superiores del retablo, «Petición de la mano de santa Úrsula, El embajador de Inglaterra da cuenta a su rey de los acontecimientos de su misión, Bautismo de Conan en presencia de Santa Úrsula y su padre y Llegada a Inglaterra de santa Úrsula", pertenecieron al coleccionista bilbaíno Antonio Gorostiza, aunque en 1992, el Museo Nacional del Prado las compró en la subasta celebrada en Sotheby's Madrid por la nada desdeñable suma de 79660000 de pesetas, cuantía económica posibilitada gracias los fondos procedentes del legado Villaescusa (VV. AA. 1993; VV. AA. 1995).

La predela del conjunto contenía siete imágenes de santos mártires emparejados, a excepción de una de las piezas, hoy en día en paradero desconocido, la cual, según las investigaciones de Charles Post, podía haber representado a santo Domingo (Post 2014).

Las tablas que muestran por un lado a santa Catalina y san Sebastián, y por el otro a santa Margarita y san Zoilo, fueron propiedad del célebre coleccionista y abogado americano John G. Johnson, quien legó sus más de mil obras artísticas a la ciudad de Filadelfia, con la condición de que éstas fueran expuestas en el que fuera su hogar. Aunque la Casa-Museo se inauguró en 1923, no permanecería muchos años abierta, ya que no tenía óptimas condiciones para la exhibición de las piezas, por lo que fueron transferidas al Philadelphia Museum of Art, donde se encuentran en la actualidad?

${ }^{5}$ Las cuales se corresponden con las representaciones de Santa Úrsula habla con las mártires, La llegada de Santa Úrsula a Roma, La condena a muerte de Santa Úrsula y El Martirio de Santa Úrsula.

${ }^{6}$ Sharples, J. (s.d.).

7 Graffton Gallery 1913.

${ }^{8}$ Royal Academy, 1920-1921.

9 Philadelphia Museum of Arts. 
La restante pintura de la predela, en la que aparecen san Bartolomé y santa María Magdalena, se ubica en el Zornmuseet -Mora, Suecia-, recinto museístico que acoge la casa y gran parte de la producción del pintor Anders Zorn, quien, además de ser un reconocido retratista, también adquirió obras artísticas para su residencia. Es posible que las pinturas de la iglesia de San Pablo fueran adquiridas en uno de sus frecuentes viajes a España, ya que existen constancias de que visitó en al menos ocho ocasiones la Península (Sandström 1992).

La autoría del conjunto retablístico -las ocho tablas del cuerpo y las seis de la predela- ha sido muy cuestionada desde su "redescubrimiento", ya que expertos como Mayer, Berenson y Post lo relacionaban con la escuela de Niza (Mayer 1915), la zona del Piamonte -con influencias de Jacques Durandi- (Berenson 1913) y la escuela catalana (Post 2014), respectivamente, aunque este último investigador, Charles Post, más adelante lo relacionó con las escuelas castellanas y aragonesas.

Por su parte, Gaya Nuño señaló que su autor podía ser el Maestro de Villamediana, activo en el ámbito palentino (Gaya Nuño 1958), pero tanto Gudiol como Yarza lo atribuyeron a la escuela valenciana y lo fecharon en torno a 1400-1410 (Yarza 1993), siendo el primero quien propuso las semejanzas estilísticas entre este conjunto y el retablo de san Jorge (Gudiol 1955) del Museo de Jérica (Castellón) -antes en la iglesia de misma advocación y realizado por Berenguer Mateu entre 1430-1431-.

Actualmente, tanto el Museo Nacional del Prado como The Lady Lever Art Gallery tienen sus piezas catalogadas como anónimas de la escuela valenciana; si bien la pinacoteca española las data entre 1425-1450, la británica retrasa su ejecución hacia 1400-1410. Por su parte, el Philadelphia Museum of Art cataloga las tablas como ejecución del valenciano Jaume Mateu en torno a 1450.

En todas las obras se pueden observar las principales características de la pintura gótica de la primera mitad del siglo xv, como el abundante uso del pan de oro, la concepción de figuras estilizadas, el movimiento en ropajes, así como la incorporación de detalles en la ambientación o en los fondos (Pitarch 1982).

La temática escogida tuvo una enorme difusión durante la Edad Media gracias a su inclusión en La Leyenda Dorada de Jacopo de la Vorágine, y en la propia ciudad castellana fue destacada, ya que en la seo palentina existía una capilla dedicada en exclusiva a santa Úrsula y las once mil vírgenes, en la cual se custodiaba la cabeza momificada de Córdula, la única doncella que escapó y se escondió de los hunos, pero arrepentida por no aceptar el martirio, se entregó a sus enemigos (Ferreiro 1991).

\section{RETABLO DE LA PIEDAD}

El primer retablo ejecutado en el siglo Xvi de la iglesia dominica es el que se sitúa en la Capilla de las Angustias, recinto que en su día perteneció a Gonzalo Zapata, deán del Cabildo de la catedral de Palencia desde 1479 hasta su fallecimiento en 1519.

Por el momento no se han encontrado testimonios documentales de los motivos por los que el religioso finalmente eligió el templo de San Pablo para su ente- 


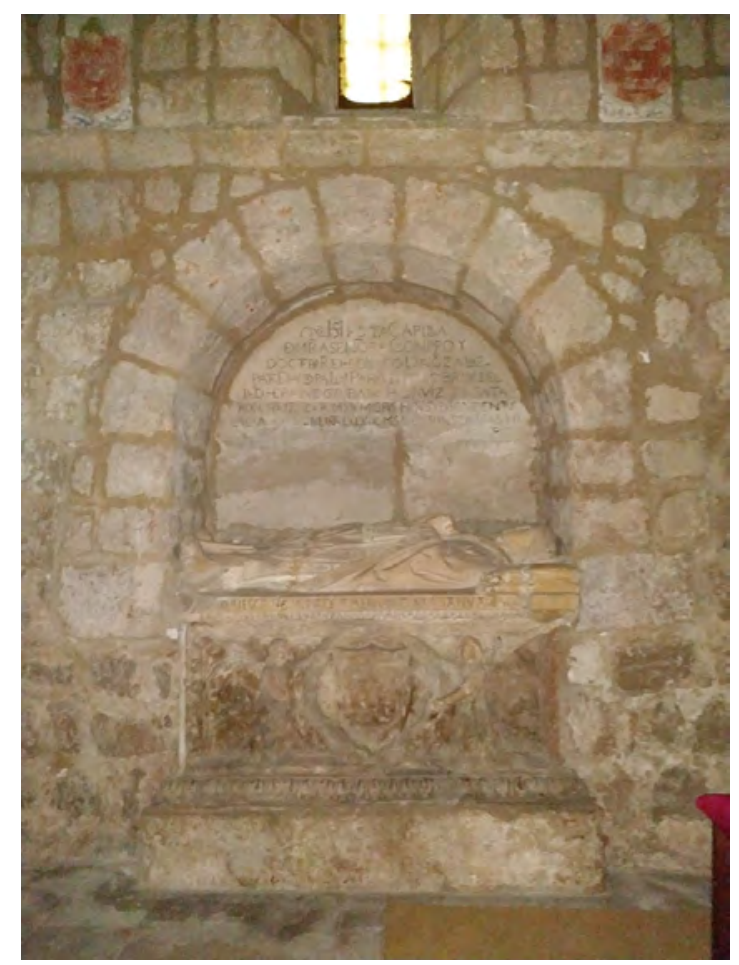

Fig. 3. Escuela castellana, sepulcro del deán Gonzalo Zapata, ¿1519? Fotografía: Ester Prieto Ustio.

rramiento y el de sus familiares, ya que se conserva una solicitud del 21 de junio de 1499 en la que ruega al Cabildo su inhumación en la seo palentina (Ara 1989).

Aún en vida, el deán Zapata emprendió toda una modificación del espacio para convertirlo en panteón familiar, llevando a cabo acciones como la incorporación de un arco de comunicación entre la capilla y el antiguo presbiterio, la ejecución del sepulcro y un retablo, así como el cerramiento de la misma, con una interesante reja fechada a comienzos del Quinientos y vinculada al taller de Alonso Relojero, en la que aún se observan elementos gotizantes, como el remate a modo de friso calado por dientes de sierra y arquillos, que se corona con un entrelazamiento de arcos conopiales (Andrés 1990).

La tumba del religioso se ubica en un arcosolio, en cuyo fondo aparece una inscripción en la que se indica su propiedad y patrocinio. En el frontal del conjunto, en mal estado de conservación, se sitúan dos ángeles portando el escudo de armas de la familia, y sobre un camastro se observa una escultura funeraria del deán yacente descansando sus manos en el pecho (fig. 3). 


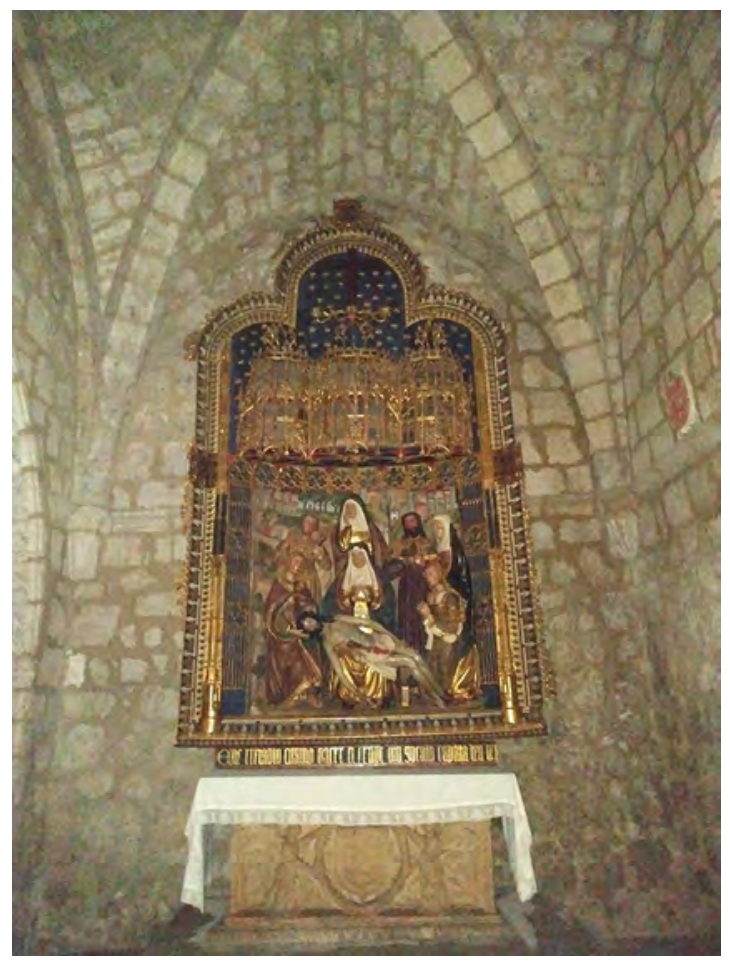

Fig. 4. Escuela castellana, retablo de la Piedad, iglesia de San Pablo (Palencia), 1516. Fotografía: Ester Prieto Ustio.

El retablo de la Piedad fue llevado a cabo en torno a 1516 (Quadrado 1885), $\mathrm{y}$ al igual que con el dispersado conjunto anterior, existen muchas dudas sobre su autoría, siendo vinculado por diversos expertos sobre escultura castellana al círculo de Felipe Vigarny, aunque la composición es demasiado arcaizante para los modelos que se trabajaban en esas fechas el taller del de Borgoña (Portela 1977). También se ha puesto en relación con el retablo mayor de la iglesia de Santa María de Dueñas, ejecutado entre 1510-1518 por Alonso de Ampudia, Pedro Manso y Antonio de Malinas (Martínez 2002), con claras trazas aún tardogóticas, sobre todo por los elementos arquitectónicos que enmarcan el retablo. Esta influencia aún medieval ha hecho que se piense en la atribución a Alejo de Vahía (Yarza 1987), o bien a algún taller del entorno vallisoletano (Ara 1974), pero no hay nada claro por el momento.

El original conjunto se compone de un altorrelieve que representa el Llanto sobre Cristo muerto, rematado por un juego arquitectónico de tracerías gotizante, sobre el que se coloca una cruz -quizás pudiera haber sido un Calvario o la representación de un Cristo en la cruz- y la representación celeste, enmarcado todo en un arco trilobulado (fig. 4). 


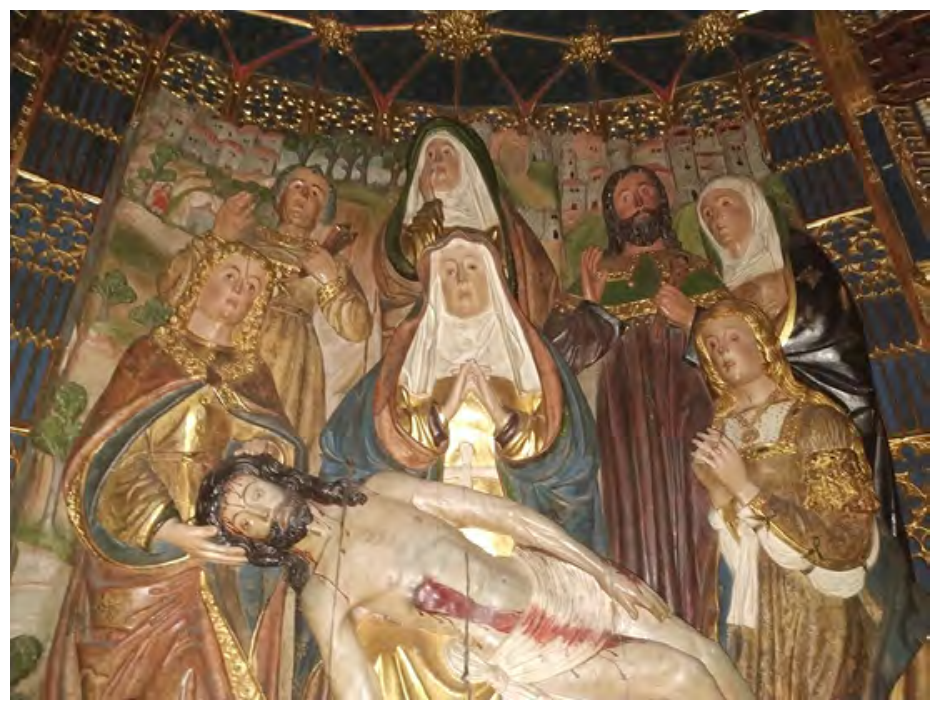

Fig. 5. Detalle de Escuela castellana, retablo de la Piedad, iglesia de San Pablo (Palencia), 1516. Fotografía: Ester Prieto Ustio.

Conformado en tres planos, el primero muestra a san Juan sustentando la cabeza de un Jesús ya muerto, mientras que la Virgen porta el cuerpo de su hijo en su regazo y María Magdalena, orante, se acompaña por el tarro de perfumes a sus pies. En el segundo, se representan las figuras de José de Arimatea, María Cleofás, Nicodemo y María Salomé, mientras que en el último podemos observar la entrada de una ciudad con una sensación de cierto abigarramiento.

El dramatismo de la escena se logra con la representación de los gestos de dolor en los rostros de los personajes, ciertamente alargados, con marcadas cejas, labios gruesos y carnaciones en los mofletes. También podemos comprobar el dinamismo con el movimiento de manos en el caso de Nicodemo, José de Arimatea -que portan los clavos y las tenazas que usaron para bajar a Jesús de la cruz- y María Salomé, así como el carácter realista de la figura de Cristo, con unas heridas muy sangrantes y un buen estudio anatómico de un cuerpo que cae sin vida, algo que será muy característico en Castilla (fig. 5).

Destacan las vestimentas, relacionadas con la moda de la época, como la capa que porta san Juan o el vestido brocado que lleva María Magdalena, quien viste de manera diferente que el resto de Santas Mujeres, ya que éstas se representan con grandes capas, pesadas túnicas y toca en la cabeza. Es muy interesante el tratamiento de los plegados, con una gran caída, lo que da mucha consistencia y corporeidad a las esculturas.

Existen composiciones similares, aunque de menor calidad artística, en otros puntos de la provincia, como en la iglesia de Santa Eugenia (Astudillo), en el tem- 


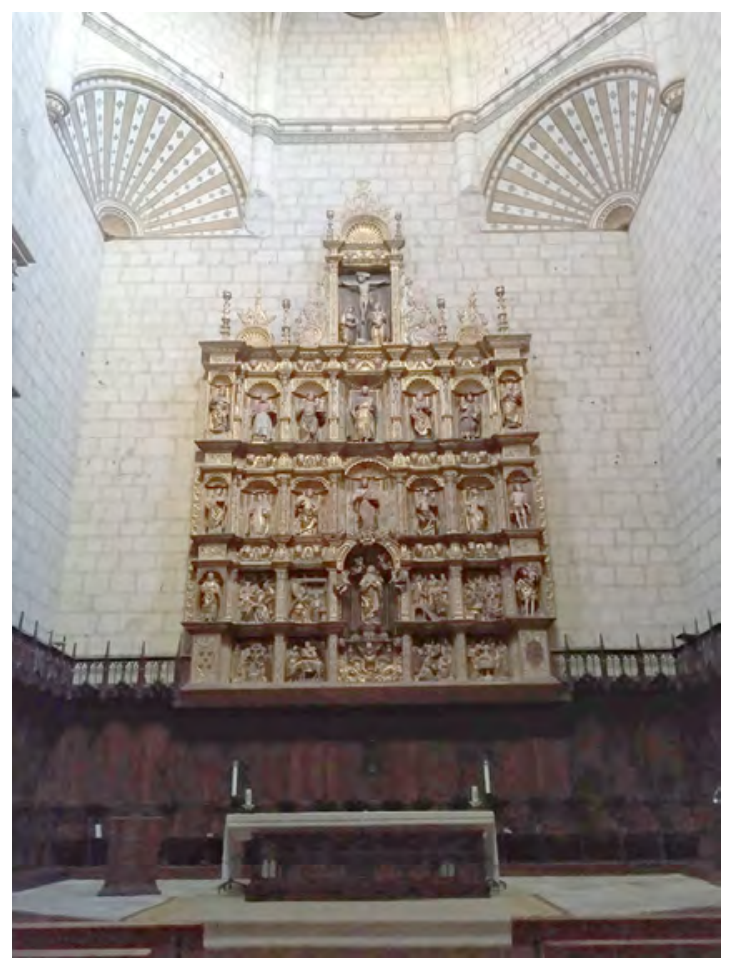

Fig. 6. Escuela castellana, retablo Mayor, iglesia de San Pablo (Palencia), ca. 1526. Fotografía: Ester Prieto Ustio.

plo de San Cornelio y San Cipriano (San Cebrián de Campos) o el ubicado en el Museo Diocesano y procedente de San Cebrián de Campos (Portela 1977).

\section{RETABLO MAYOR}

El retablo mayor de San Pablo, ejecutado alrededor de 1520 y atribuido tanto al círculo de Felipe Vigarny (Weise 1925, Proske 1952 y Azcárate 1958) como a Juan Ortiz el Viejo (Parrado 2003-2004 y Diccionario Biográfico electrónico de la Real Academia de la Historia), constituye una de las obras renacentistas más destacadas de la provincia (fig. 6).

Su principal modelo fue el propio retablo mayor de la catedral palentina (Revilla 1950), cuyas trazas fueron realizadas por Pedro de Guadalupe a partir de 1504 tras el encargo del obispo Diego de Deza, quien había contemplado el realizado por el mismo artífice en el Colegio de Santa Cruz de Valladolid. Las esculturas y pinturas que lo conforman fueron llevadas a cabo por los mejores artistas del 
ámbito castellano del momento, como Alejo de Vahía, Felipe Vigarny, Juan de Valmaseda, Juan de Flandes, y ya en el siglo XVII, Gregorio Fernández.

Este monumental retablo, con tres cuerpos, predela, ático y once calles separadas por pilastras, es uno de los primeros realizados siguiendo las directrices platerescas en toda España, y se convirtió en referencia para obras posteriores tanto en la ciudad como en los entornos vallisoletanos y burgaleses (Huerta 2001).

También el dominico se relaciona con el retablo de san Gregorio de la seo, ya que éste sigue un esquema muy plano, carece de doseles y sagrario, incorpora escenas coronadas con veneras y lo más destacado es la importancia de la escena principal, que ya comienza a sobresalir espacialmente (Payo y Martínez 2014).

El conjunto, al igual que el catedralicio, sigue una tipología «de casillero», debido a que las líneas verticales y horizontales se cruzan y cortan formando una retícula. Está compuesto por tres cuerpos compartimentados en siete calles verticales y articulados por pilastras sobre las que se elevan zócalos de querubines. Inferior y superiormente se remata con banco y ático, respectivamente (Andrés 1990).

La predela y el primer cuerpo presentan una serie de ocho relieves -cuatro en cada lado- que narran la infancia de Cristo y escenas de la vida de la Virgen: Presentación de María, Anunciación, Visitación, Nacimiento, Adoración de los Magos, Circuncisión, Huida a Egipto y Jesús entre los Doctores. Los relieves del banco son flanqueados por el escudo de la familia Rojas - patronos de la capilla mayor- y la Orden de los Predicadores.

En la parte central se abre una gran hornacina que acoge una imagen de la Asunción de la Virgen acompañada de cuatro ángeles, situada encima de una repisa decorada con un angelote y elementos propiamente renacentistas -tarjas entremezcladas con motivos vegetales-. En los extremos de los relieves -anexos a la escultura-, flanquean el cuerpo las imágenes de san Juan Evangelista y san Cristóbal.

El segundo y el tercer cuerpo se componen de figuras insertas en hornacinas aveneradas, representando a los santos más destacados de la orden dominica y de la devoción palentina. El cuerpo central -de izquierda a derecha- muestra a san Antolín, patrón de la ciudad; santa Catalina de Siena, portando su corazón en la mano y una corona de espinas sobre la testa; santo Domingo de Guzmán, el ilustre fundador del convento, acompañado de un perro con una antorcha en la boca; en el centro y de tamaño mayor aparece san Juan Bautista, acompañado por un cordero y la piel de camello; santo Tomás de Aquino, con el cuerpo de Cristo dentro de un cáliz y éste encima de un libro; san Pedro Mártir de Verona y san Sebastián.

En el último cuerpo se encuentra san Gregorio, con una paloma en su hombro; san Pío V, cuya escultura fue añadida posteriormente; san Antonio de Padua, acompañado del Nińo. En la zona central y de mayores dimensiones se coloca a san Pablo, titular del templo, junto con su atributo más destacado, la espada; santa Lucía, con una bandeja en la que porta sus ojos, como símbolo de su martirio; Santiago, ataviado como un peregrino, y santa Ana triple, acompañada por la Virgen y en Niño sobre sus rodillas.

El ático, de composición rectangular y delimitado por pilastras, se remata por un arco carpanel con una venera. En él se sitúa un Calvario, cuyo Cristo sirvió de inspiración para obras posteriores, como así se puede observar en el Crucificado 
realizado por Juan Ortiz para la iglesia de Nuestra Señora de la Asunción de Marcilla de Campos, y los situados en los templos de Castronuevo de Esgueva y Arrabal de Portillo, en la provincia de Valladolid (Parrado 2003-2004).

Las novedades que aporta este retablo son su acusada verticalidad gracias al uso de pilastras, el uso de cabezas de putti como elementos de separación en los frisos y la independencia del ático del propio corpus retablístico. Tanto las veinte esculturas -contando con el Calvario- como los ocho relieves comparten mismos aspectos formales, y al no contar con documentación sobre el encargo de esta obra, como ya hemos señalado, los especialistas han vinculado su hechura a Felipe Vigarny y su círculo más cercano, o a Juan Ortiz el Viejo. Ante la ausencia de datos documentales y no contar con una única teoría acerca de su autoría, lo que sí podemos afirmar es que quien realizó la pieza destaca por las cuidadas proporciones, la simetría corporal, la minuciosidad del estudio anatómico, rostros armónicos, el uso del contrapposto y monumentalidad en los ropajes -como mantos amplios a la manera de togas, plegados finos y crispados y paños que descienden hacia el suelo-.

Este retablo influyó en otras composiciones de la zona, como el que se encuentra en la capilla del sagrario de la catedral de Palencia, iniciado en 1529 por Ortiz, artistas de los círculos de Valmaseda y del propio Vigarny. También presenta una combinación de relieves y esculturas, utiliza pilastras y el ático goza de gran protagonismo, separándose del propio retablo. Las mismas características aparecen en el retablo mayor de la iglesia de San Cornelio y San Cipriano de San Cebrián de Campos, elaborado también por Juan Ortiz en fechas cercanas (De la Casa 2002).

\section{SEPULCRO-RETABLO DE LOS I MARQUESES DE POZA}

La capilla mayor de la iglesia de San Pablo fue utilizada como panteón familiar de los marqueses de Poza ${ }^{10}$. Juan de Rojas y Rojas, nacido en Monzón de Campos, recibió este título -antes señorío- por parte de Carlos V en 1537, convirtiéndose en el primero de su familia en ostentarlo. Casado con Marina de Villandrando ${ }^{11}$, hija de los condes de Salinas, fue un hombre fiel a la Corona incluso durante la revuelta comunera -en la que asaltaron su castillo burgalés de Mazuelo de Muñó-, por lo que sería nombrado alcalde y escribano mayor de los hijosdalgo en los reinos de Castilla, según la disposición firmada por Carlos I en $1548^{12}$ (fig. 7).

Antes de ostentar el marquesado, ya en 1514, De Rojas adquirió la capilla mayor del templo para su enterramiento, por lo que se llevó a cabo una remodelación espacial para adaptarla a las nuevas tendencias artísticas, así como al gusto del

${ }^{10}$ Entre los siglos XIV y XVI, esta capilla acogió las sepulturas de destacados personajes como don Nuńo González de Lara y su esposa, doña Teresa Alfonso, o lo señores de Montealegre, don Pedro Manuel y doña Juana Manrique (Andrés 1990).

${ }^{11}$ Las capitulaciones del enlace y los asuntos relacionados con la dote de Marina pueden consultarse en el Archivo Histórico de la Nobleza, Altamira, C.1, D.15.

12 Archivo de la Real Chancillería de Valladolid, Secretaría del acuerdo, Caja 2, 17. 


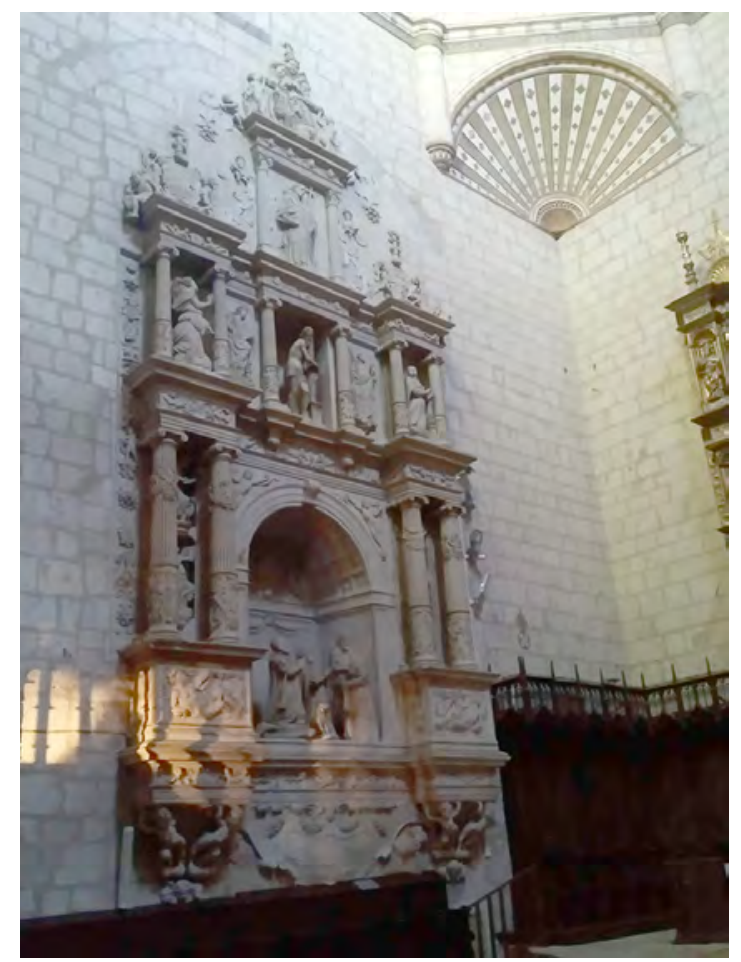

Fig. 7. Escuela castellana, sepulcro-retablo de los I marqueses de Poza, iglesia de San Pablo (Palencia), 1559. Fotografía: Ester Prieto Ustio.

noble, quien, además de su relación con este templo, dotó en 1556 de una capellanía a la iglesia del pueblo palentino de Valdespina ${ }^{13}$.

El sepulcro se finalizó en 1559 , y, al igual que con el resto de retablos de esta iglesia, su autoría siempre ha estado muy discutida, pensándose en Alonso Berruguete y Francisco Giralte (Salvador 1997), aunque en la actualidad se mantienen las teorías de Parrado del Olmo, atribuyéndose las trazas a Juan Sanz de Escalante y las esculturas a Manuel Álvarez y Juan Ortiz Fernández (Parrado 1981).

Hemos incluido esta pieza en nuestro breve estudio, ya que, aunque no es formalmente un retablo, la organización del enterramiento se lleva a cabo a la manera de éste, inspirándose tanto en modelos italianos como en el sepulcro de don Rodrigo de Mercado, conservado en la iglesia de San Miguel de Ońate, realizado por Diego de Siloé a finales de los años cuarenta del siglo Xvi (Andrés 1990). También su orga-

${ }^{13}$ Archivo Histórico de Nobleza, Altamira, C.1, D.33. 
nización recuerda a los esquemas arquitectónicos de las iglesias de San Miguel de Villarramiel o la parroquia de Tudela de Duero (Zalama 1987).

Como si fuera un arco triunfal, el conjunto se divide en dos cuerpos, tres calles, predela y ático, siendo sus materiales constructivos la piedra -probablemente procedente de la zona norte de la provincia, donde existían importantes canterasy alabastro.

El macizo basamento recoge las columnas superiores del cuerpo central por medio de unos remates sostenidos por putti, mientras que la parte central está formada por una cartela simulando una gran tarja, decorada con racimos de uvas y motivos a candelieri, en la que se puede leer la siguiente inscripción:

Aquí yace el muy ilustre Seńor D. Juan de Roxas, Marqués de Poza, y la muy ilustre Señora $\mathrm{D}^{\mathrm{a}}$. Marina Sarmiento su muger, el qual mandó hacer esta obra. Murió a primero de Agosto ańo de mil quinientos y cinquenta y ocho, acabose esta obra a diez y seis de Enero de mil quinientos y cincuenta y nuebe ${ }^{14}$.

En los laterales del primer cuerpo, a cada lado del enterramiento, aparecen dos columnas pareadas, con el fuste estriado y el tercio inferior tallado, las cuales se alzan sobre sólidas bases rectangulares, decoradas con relieves de alegorías, en la parte izquierda la Castidad y la Justicia, ambos personajes representados con sus principales atributos. En sus estrechos intercolumnios, encontramos hornacinas aveneradas en las que se sitúan los cuatro evangelistas. Las columnas son rematadas por un sistema de entablamento arquitrabado decorado por amorcillos (Parrado 1981).

La parte central se compone de un profundo arcosolio -formado por un arco de medio punto con el interior casetonado- en el que colocan las figuras orantes de Juan de Rojas y María Sarmiento, realizadas en alabastro, los cuales destacan por su realismo y el detallismo a la hora de representar los ropajes, los cuales eran la moda del momento. En los flancos del arco se representa un relieve de san Jerónimo penitente y otro de san Juan Bautista -patrón del marqués-. En el fondo del conjunto aparece un cortinaje, en cuyo tímpano observamos una Virgen acompañada del Niño y una serie de ángeles que portan las arma Christi.

Los laterales del segundo cuerpo son muy similares a los del anterior, aunque en este caso tienen una dimensión menor y hay más espacio en los intercolumnios, en los que se representa la Anunciación, situándose el arcángel Gabriel en el lado izquierdo y la Virgen en el derecho. El espacio central es idéntico a los laterales, aunque en él se sitúa una interesante escultura en alabastro de Cristo atado a la columna. Entre el cuerpo central y los laterales, aparecen dos relieves de dos de los santos dominicos por excelencia, santa Catalina de Alejandría y san Antonio de Padua (Redondo 1987).

El ático, trabajado con más planismo, se forma con dos columnas corintias con el fuste estriado, entre las cuales se ubica un altorrelieve del fundador de la

\footnotetext{
${ }_{14}$ Real Academia de la Historia.
} 
Orden, mientras que extremos aparecen los escudos de armas del matrimonio, y en la parte superior, la imagen de Dios Padre.

Esta tipología funeraria fue pionera en Palencia y su provincia, siendo el sepulcro de los I marqueses de Poza fuente de inspiración para otras obras, como se puede comprobar en el sepulcro de Fadrique de Acuña, conde de Buendía (López Yepes y López Yepes 1977), situado en la iglesia de Santa María de Dueñas y en el que también intervino Manuel Álvarez.

\section{SEPULCRO-RETABLO DE LOS III MARQUESES DE POZA}

Situado enfrente del enterramiento anterior, éste acoge los cuerpos de Francisco de Rojas y Enríquez y su esposa Francisca Enríquez de Almansa, terceros señores del marquesado de Poza.

Francisco ${ }^{15}$, nieto de Juan de Rojas, fue un destacado cortesano durante los reinados de Felipe II y Felipe III. Caballero de la Orden de Alcántara ${ }^{16}$, fue señor de Monzón, Cabia, Serón y Valdespina, alcalde mayor de los hijosdalgo de Castilla -cargo que también ostentó su abuelo, como acabamos de ver-, merino mayor de Burgos, presidente del Consejo de Hacienda ${ }^{17}$ y miembro del Consejo de Estado (Salazar y Castro 1697) (fig. 8).

El sepulcro fue encargado por Francisca, hija de los marqueses de Alcañices y gran benefactora del monasterio, ya que en su testamento otorgó al mismo un juro de 4500 maravedíes $^{18}$. Aunque su esposo falleció en 1605, el contrato para la construcción de su lugar de reposo tuvo lugar en 1609 en Valladolid entre la marquesa y los ensambladores Cristóbal y Francisco Velázquez, Antonio de Riera y Juan de Muniátegui, y el maestro cantero Antonio de $\mathrm{Arta}^{19}$. Parece ser que también colaboró en la obra Antonio Riera, pero su nombre no figura en la documentación del encargo. Antes de este encargo, la marquesa concertó la obra con el escultor Alonso de Vallejo, asentado en Madrid, pero se desconocen los motivos de la ruptura de este encargo (Martín 1958). Como hemos podido ir observando en este estudio, ésta es la única obra hasta el momento de la que se tiene constancia documental de su encargo y de los artistas que en ella trabajaron.

Con una marcada influencia de los Leoni, los hermanos Pompeo y Leone a partir de sus intervenciones en El Escorial (Martín 1951-1952) propusieron una

${ }^{15}$ Es posible que este personaje sirviera de inspiración al poeta Friedrich Schiller para la creación del personaje del marqués de Posa (o Poza) de la obra Don Carlos -1783-1787- y a su vez para la adaptación a la ópera que llevó a cabo Giuseppe Verdi en 1867 con Don Carlo.

${ }_{16}$ Archivo Histórico Nacional, OM-Caballeros_Alcantara, Exp. 1309.

${ }_{17}$ Muy interesante es la correspondencia al respecto de asuntos relacionados con este Consejo mantenida entre Rojas y Cristóvão de Moura e Távora, marqués de Castel-Rodrigo y virrey de Portugal. Biblioteca Nacional de España, Mss/6178.

${ }_{18}$ Archivo General de Simancas, CME, 783, 3.

19 Véase Anexo Documental (García, 1951). 


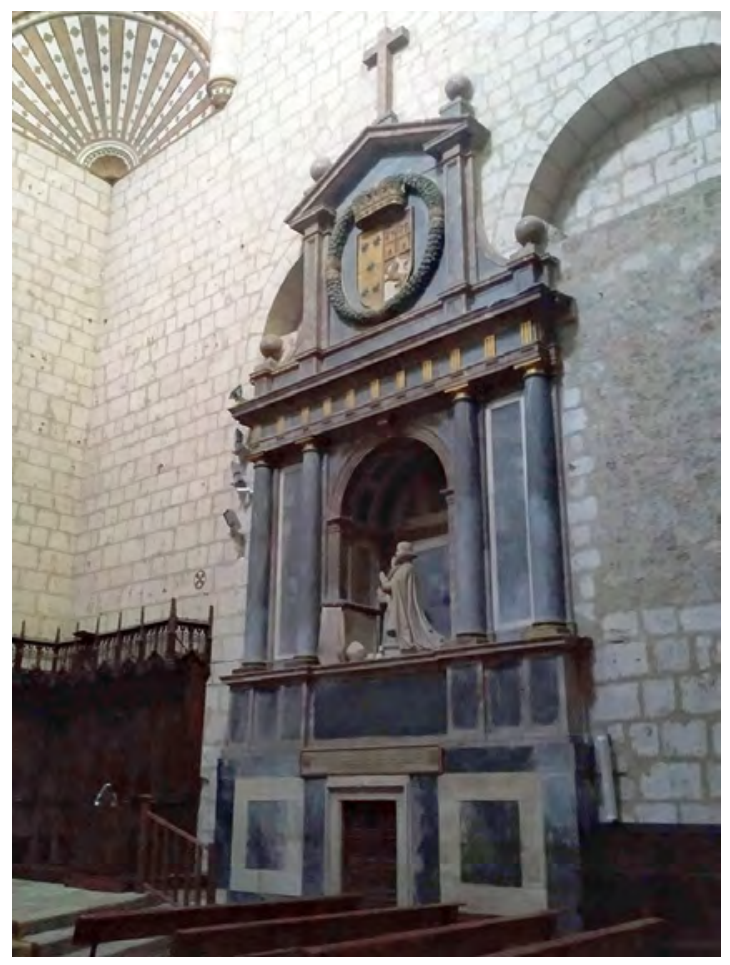

Fig. 8. Cristóbal y Francisco Velázquez, Antonio de Riera y Juan de Muniátegui, sepulcro-retablo de los II marqueses de Poza, iglesia de San Pablo (Palencia), ca. 1609. Fotografía: Ester Prieto Ustio.

vuelta a figuras más clasicistas, más estáticas, siguiendo un canon ciertamente idealizado, dotándolas de serenidad y distanciándose así de la tensión, los cánones alargados y las formas manieristas. A partir del retablo del monasterio madrileño-cuyas trazas fueron dadas por Juan de Herrera-, se prima la concepción arquitectónica, con espacios delimitados, una ausencia decorativa y se incorpora el uso de materiales como el mármol y el bronce.

El panteón de los marqueses, que sigue estas propuestas, es realizado en mármol, jaspe y bronce dorado, componiéndose de un único cuerpo dividido en tres calles y se acompaña de un gran ático y predela, primando la influencia de la arquitectura. En la parte más inferior del conjunto, se ubica una pequeña puerta por la que se accede a un reducido espacio donde están los cuerpos de los difuntos. Sobre ésta, aparece una sencilla predela con juegos cromáticos conseguidos con la combinación de jaspe y mármol en los laterales, y en la parte central se observa una inscripción con datos sobre los esposos.

Los laterales están formados por dos estrechas columnas muy clásicas, con el fuste liso de jaspe y rematadas en mármol y bronce. Los intercolumnios los com- 


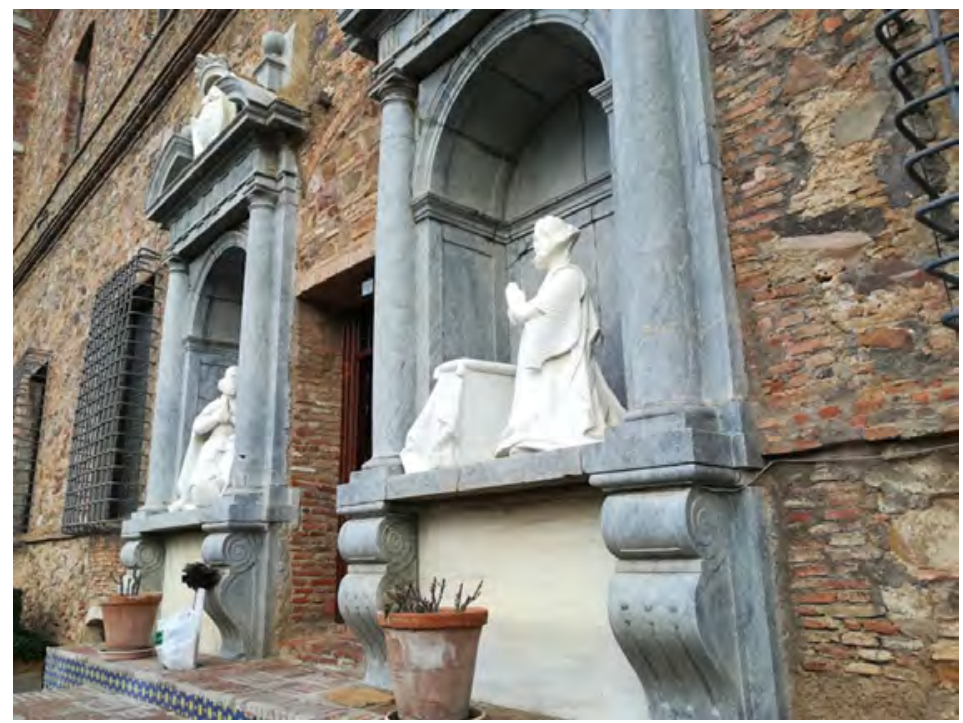

Fig. 9. Antonio de Riera, sepulcros de Alonso de Guzmán y María de Figueroa, Archivo-Museo Álvaro de Bazán (El Viso del Marqués), 1613. Fotografía: Ester Prieto Ustio.

ponen una combinación bícroma entre el verde jaspe y el mármol. Por encima de ellos se añade un sencillo entablamento con pequeñas aplicaciones verticales de bronce dorado.

El espacio central lo compone un arco de medio punto con profundidad, en el que se colocan las esculturas de los fallecidos. El matrimonio aparece rezando ante un pedestal marmóreo, vestidos a la moda cortesana de Felipe III, portando la popular gorguera. A los pies de Francisco se coloca un yelmo, aludiendo su pertenencia a una orden militar. El ático se remata con un frontón triangular, simulando una espadaña, acompañado por bolas de tradición escurialense. En él se coloca entre una guirnalda de motivos vegetales el escudo de la familia, único elemento que rompe con los materiales constructivos y los colores de la composición.

Esta obra inspiró el conjunto funerario de don Alonso de Guzmán y María de Figueroa, originariamente para el monasterio de Nuestra Señora de la Concepción de Viso del Marqués -Ciudad Real- (Marías 1978). Este enterramiento fue encargado al escultor Antonio de Riera en 1613, y actualmente se encuentra en los jardines del Archivo-Museo Álvaro de Bazán, edificio que fuera palacio de los marqueses de Santa Cruz (fig. 9). 


\section{CONCLUSIONES}

Como hemos podido ir observando a lo largo de este breve estudio, la actual iglesia palentina de San Pablo y exconvento dominico fue un destacado recinto de la ciudad a lo largo de la Edad Media y la Edad Moderna, tanto por las condiciones de su fundación, los acontecimientos allí desarrollados y los personajes que en él reposan como por las obras de arte que se custodian o custodiaron entre sus muros.

Durante los siglos XV y XVII, las más novedosas tendencias artísticas se dieron cita en este templo, desde la pintura gótica valenciana o la escultura gótica-flamenca, pasando por retablos renacentistas y enterramientos con claras dependencias italianizantes y escurialenses, estilos y ejemplos que ponen de manifiesto la relevancia de la ciudad en esas centurias.

Su situación geográfica, recursos naturales y económicos propiciaron que Palencia y su provincia se convirtieran, junto con Valladolid y Burgos, en un destacadísimo foco cultural en el cual se dieron cita artistas de muy diversas disciplinas y procedencias, además de ser cantera y lugar de nacimiento de importantes creadores del momento, por lo que la iglesia de San Pablo se convierte en un excelente paradigma para poder analizar la acusada evolución estilística desarrollada a lo largo de estos dos siglos, tránsito del Medievo a la Modernidad.

Recibido: 14 de febrero de 2020; ACeptado: 21 de septiembre de 2020 


\section{REFERENCIAS}

Andrés, S. (1990). «Los Dominicos en Palencia: El convento de San Pablo», en VV. AA. Jornadas sobre el arte de las Órdenes religiosas en Palencia. Palencia: Diputación Provincial de Palencia. pp. 71-110.

Ara, C. (1974). En torno al escultor Alejo de Vahía: 1490-1510. Valladolid: Universidad de Valladolid. $92 \mathrm{pp}$.

Ara, C. (1989). «La actividad artística en la catedral de Palencia durante los obispados de Diego Hurtado de Mendoza y Fray Alonso de Burgos (1471-1499)», en VV. AA. 1989. Jornadas sobre la Catedral de Palencia. 1 al 15 de agosto de 1988. Palencia: Diputación Provincial de Palencia. pp. 67-104

Atrins, C. (2018). The John G. Johnson Collection: A History and Selected Works. Philadelphia: Philadelphia Museum of Art. 845 pp.

Azcárate, J.M. (1958). Escultura del siglo XVI. Ars Hispaniae, vol. XIII. Madrid: Plus Ultra. 395 pp.

Berenson, B. (1913). Fichas números 260 y 261, en Graver Johnson, J. Catalogue of a Collection of Paintings and Some Art Objects (Johnson Collection), volumen I. Philadelphia: J.G. Johnson $488 \mathrm{pp}$.

CaSAdo, H. (2018). Comercio, finanzas y fiscalidad en Castilla (siglos XVYXVI). Barcelona: Midac. 340 pp.

De la Casa, E.M. (2002). «El retablo de la Piedad de San Cebrián de Campos». Publicaciones de la Institución Tello Téllez de Meneses. 73: 401-420.

Del Río, I. (2001). El escultor Felipe Bigarny, (h.1470-1542). Valladolid: Junta de Castilla y León, Consejería de Educación y Cultura. 450 pp.

Domínguez, S. (2017). El convento dominico de San Pablo de Palencia (1220-1600): breve reseña histórica y colección diplomática. Salamanca: San Esteban Editorial. 771 pp.

Esteban, A. y Valdeón, J. (1985). «Esbozo de una geografía social. Palencia a fines de la Edad Media». Studia historica. Historia medieval. 3: 117-142.

Fernández de Madrid, A. (1932). Silva palentina. Palencia: Imprenta de El Diario Palentino. 849 pp.

Fernández, M.A. (2012). Juan de Juni: escultor. Valladolid: Universidad de Valladolid, Secretariado de Publicaciones e Intercambio Editorial. 230 pp.

Ferreiro, J. (1991). La leyenda de las once mil virgenes: sus reliquias, culto e iconografía. Murcia: Editum. 340 pp.

Fuente, M.J. (1989). La ciudad de Palencia en el siglo XV. Aportación al estudio de las ciudades castellanas en la Baja Edad Media. Madrid: Editorial Universidad Complutense. 631 pp.

Fuente, M.J. (2012). La primera universidad hispana: el estudio general de Palencia. Palencia: Cálamo. $304 \mathrm{pp}$.

García, A. y Alonso, B. (1981). Synodicon Hispanum: Burgos y Palencia. Madrid: Biblioteca de Autores Cristianos. 800 pp.

García, E. (1951). Palencia. Papeletas de Historia y Arte. Palencia: Artes Gráficas Mazo 211 pp.

García. P. (1986). La Ciudad de Palencia en el siglo XIX: la desamortización y su transformación urbanistica (1836-1868). Palencia: Diputación Provincial de Palencia. 432 pp.

GaYa, J.A. (1958). La Pintura Española fuera de España. Historia y Catálogo. Madrid: España-Calpe. $371 \mathrm{pp}$. 
Gómez-Moreno, M. (1963). Diego Siloé: homenaje en el IV centenario de su muerte. Granada: Universidad de Granada. 105 pp.

González, J. (1984). Historia de Palencia. Palencia: Diputación Provincial de Palencia. 646 pp.

Graffton Gallery (1913). Illustrated catalogue of the exhibition of Spanish old masters in support of National Gallery funds and for the benefit of the Sociedad de Amigos del Arte Española, Oct. 1913 to Jan. 1914 [Internet]. En Internet Archive. [Cited 17 ene 2020]. Available from https://archive.org/details/illustratedcatal00grafiala/page/8/mode/2up.

Gudiol, J. (1955). La pintura gótica. Ars Hispaniae, vol. Ix. Madrid: Plus Ultra. 420 pp.

Hoyos, J. (2013). Alonso Berruguete, su obra e influencia: actas del curso de la Universidad "Casado del Alisal». Palencia: Diputación Provincial de Palencia. 191 pp.

Huerta, P.L. (2001). «Notas sobre el retablo mayor de la catedral de Palencia». Pátina, 10-11: 240-259.

Junta de Castilla y León [Internet]. En Catálogo de Bienes Protegidos de la Junta de Castilla y León [cited 18 ene 2020]. Available from https://servicios.jcyl.es/pweb/datos.do?numero= 7558\&tipo=Inmueble\&ruta $=$.

López Yepes, A. y López Yepes, J. (1977). «El Monte de la Piedad de Dueńas (Palencia) fundado por D. Fadrique de Acuña, Conde de Buendía (c. 1550)». Boletín de documentación del Fondo para la Investigación Económica y Social, 9-2: 364-388.

Marías, F. (1978). "Antonio de Riera en El Viso del Marqués». Boletín del Seminario de Estudios de Arte y Arqueología. 44: 477-478.

Mayer, A. (1915). «Die spanischen Azulejos und ihre Bedeutung für die Erforschung der Quattrocentomalerei». Der Cicerone: Halbmonatsschrift für die Interessen des Kunstforschers \& Sammlers. 7: 66-70.

Martín, J.J. (1951-1952). «Sobre la intervención de León Leoni en el retablo del Escorial». Boletín del Seminario de Estudios de Arte y Arqueología. 18: 126-127.

Martín, J.J. (1958). Escultura barroca castellana. Madrid: Fundación Lázaro Galdiano. 425 pp.

Martínez, R. (1989). La arquitectura gótica en la ciudad de Palencia (1165-1516). Palencia: Diputación Provincial de Palencia. 270 pp.

Martínez, R. (2002). «Pedro Manso y el retablo mayor de la iglesia parroquial de Dueńas (Palencia)». Publicaciones de la Institución Tello Téllez de Meneses. 73: 421-428.

Medrano, M.J. (1725). Historia de la provincia de España de la Orden de Predicadores. Madrid: Oficina de Don Gabriel del Barrio. 2119 pp.

Milicua, J. (1954). Palencia Monumental. Madrid: Plus Ultra. 155 pp.

Ministerio de Educación, Cultura y Deporte [Internet]. En Fototeca del Patrimonio Histórico: Gobierno de España [cited 1-31 ene 2020]. Available from http://www.mcu.es/fototeca_patrimonio/search_fields.do?buscador=porCampos\&limpiar=true.

Museo Nacional del Prado [Internet]. Petición de la mano de Santa Úrsula, en Colección Museo del Prado [cited 15 ene 2020]. Available from https://www.museodelprado.es/coleccion/obrade-arte/peticion-de-la-mano-de-santa-ursula/784f99ae-002a-4bd7-92b9-a3f511e1e890.

Navarro, R. 1946. Catalogo Monumental de la Provincia de Palencia. Fascículo Cuarto: Partido Judicial de Palencia. Palencia: Diputación Provincial de Palencia. 213 pp.

Parrado, J.M. 1981. Escultores seguidores de Berruguete en Palencia. Valladolid: Ediciones Universidad de Valladolid. 485 pp.

Parrado, J.M. (2003-2004). «Sobre algunas esculturas del siglo XVI». Boletín del Seminario de Estudios de Arte y Arqueología. 69-70: 303-320. 
Payo, R. y Martínez, R. (2011). La catedral de Palencia. Catorce siglos de historia y arte. Burgos: Promecal Publicaciones. 632 pp.

Pérez, F. y Rodríguez, M.V. (1995). «Iconografía de Santa Úrsula en Palencia el retablo de San Pablo de Palencia», en Calleja González, M.V., coord. Actas del III Congreso de Historia de Palencia: 30, 31 de marzo y 1 de abril de 1995. Palencia: Diputación Provincial de Palencia. pp. 763-772.

Pérez, M. (1995). «Cálices de convento de San Pablo de Palencia». Publicaciones de la Institución "Tello Téllez de Meneses». 66: 321-336.

Philadelphia Museum of Arts [Internet]. Predella panel showing Saints Margaret and Bartholomew. En Collections of Philadelphia Museum of Arts [cited 18 ene 2020]. Available from https://www.philamuseum.org/collections/permanent/102018.html?mulR=1953409991|36.

Philadelphia Museum of Arts [Internet]. Saints Sebastian and Catherine of Alexandria. En Collections of Philadelphia Museum of Arts [cited 18 ene 2020]. Available from https://www.philamuseum.org/collections/permanent/102017.html?mulR=1253344118|47.

Pitarch, A. (1982(. Pintura gótica valenciana: el periodo internacional (desde la formación del Taller de València, ca. 1374, hasta la presencia de la segunda corriente flamenca, ca. 1440-1450). Barcelona: Edicions Universitat de Barcelona. 38 pp.

Portela, F.J. (1977). La escultura del siglo XVI en Palencia. Palencia: Diputación Provincial de Palencia. 488 pp.

Post, C. (2014). A History of Spanish Painting. Volume IV-Part. 1. The Hispano-Flemish Style in NorthWestern Spain. Cambridge: Harvard University Press. 364 pp.

Proske, B.G. (1952). Castilian Sculpture, Gothic to Renaissance. Nueva York: Hispanic Society of America. 525 pp.

Quadrado, J.M. (1865). Recuerdos y bellezas de España. Valladolid, Palencia y Zamora. Madrid: Imprenta de López. 434 pp.

Quadrado, J.M. (1885). España. Sus monumentosy su arte, su naturaleza e historia. Valladolid, Palencia y Zamora. Barcelona: Establecimiento Tipográfico-editorial de Daniel Cortezo y C. ${ }^{a}$. 669 pp.

Real Academia de la Historia [Internet]. Relación de varios sepulcros de la familia de Rojas, marqueses de Poza, en el convento de San Pablo de Palencia. En Biblioteca Digital Real Academia de la Historia [cited 18 ene 2020]. Available from http://bibliotecadigital.rah.es/es/ consulta/registro.do?control=RAH20112010546.

Real Academia de la Historia. Diccionario Biográfico electrónico [Internet]. Juan Ortiz [cited 19 ene 2020]. Available from http://dbe.rah.es/biografias/57367/juan-ortiz.

Redondo, M.J. (1987). El sepulcro en España en el siglo XVI. Madrid: Centro Nacional de Información y Documentación del Patrimonio Histórico. 443 pp.

Revilla, R. (1950). Retablo mayor de la Santa Iglesia Catedral de Palencia. Publicaciones de la Institución Tello Téllez de Meneses. 5: 91-104.

Royal Academy (1920-1921). Exhibition of Spanish Painting, 3 November 1920 to 15 January 1921. [Internet]. En Arts \& Artists: Royal Academy of Arts [cited 17 ene 2020]. Available from https://www.royalacademy.org.uk/art-artists/exhibition-catalogue/1920-21-exhibition-of-spanish-painting.

SAiz, J.L y SÁnchez, J.I. (2017). «La iglesia parroquial de Guaza de Campos (Palencia) y la influencia de la Academia de San Fernando en su proyecto». BSAA arte. 83: 253-276. 
Salazar y Castro, L. (1697). Historia Genealógica de la Casa de Lara justificada con instrumentos, y escritores de inviolable fe, volumen 2. Madrid: Imprenta Real (impresor Mateo de Llanos y Guzman). $891 \mathrm{pp}$.

Salvador, J. (1997). Los conventos de Dominicos en la provincia de Palencia. Palencia: Diputación Provincial de Palencia. 598 pp.

Sharples, J. (s.d.). The National Inventory of Continental European Paintings [Internet]. En VADS: Univerity fot the Creative Arts (UK) [cited 15 ene 2020]. Available from https://vads.ac.uk/ large.php?uid $=243034 \& \operatorname{sos}=0$.

Sandström, B. (1992). «Zorn y España», en VV. AA. Sorolla-Zorn. Madrid: Ministerio de Cultura. pp. 39-48.

Urrea, J. y Martínez, R. (1978). «Construcción, proceso y derribo del arco del Mercado de Palencia (1784-1909)». Boletín del Seminario de Estudios de Arte y Arqueología Valladolid, vol. 44: 510-516.

VADS: University for the Creative Arts, NICE Paintings-National Inventory of Continental European Paintings (UK) [Internet]. Santa Úrsula habla con las mártires, en Lady Lever Art Gallery, Port Sunlight [cited 15 ene 2020]. Available from https://www.vads.ac.uk/digital/ collection/NIRP/id/30735.

VADS: University for the Creative Arts, NICE Paintings-National Inventory of Continental European Paintings (UK) [Internet]. La llegada de Santa Úrsula a Roma en Lady Lever Art Gallery, Port Sunlight [cited 15 ene 2020]. Available from https://www.vads.ac.uk/digital/ collection/NIRP/id/30869.

VADS: University for the Creative Arts, NICE Paintings-National Inventory of Continental European Paintings (UK) [Internet]. La condena a muerte de Santa Úrsula en Lady Lever Art Gallery, Port Sunlight [cited 15 ene 2020]. Available from https://www.vads.ac.uk/digital/ collection/NIRP/id/30038.

VADS: University for the Creative Arts, NICE Paintings-National Inventory of Continental European Paintings (UK) [Internet]. El Martirio de Santa Úrsula en Lady Lever Art Gallery, Port Sunlight [cited 15 ene 2020]. Available from https://www.vads.ac.uk/digital/collection/NIRP/id/30069.

VV. AA. (1989). Jornadas Sobre La Catedral de Palencia. 1 al 15 de agosto de 1988. Universidad de Verano Casado del Alisal. Palencia: Diputación Provincial de Palencia. 314 pp.

VV. AA. (1993). Un mecenas póstumo: el legado Villaescusa: adquisiciones 1992-1993. Madrid: Museo del Prado. 133 pp.

VV. AA. (1994). Paintings from Europe and the Americas in the Philadelphia Museum of Art: A Concise Catalogue. Philadelphia: Philadelphia Museum of Art. 548 pp.

VV. AA. (1995). Últimas adquisiciones: 1982-1995. Madrid: Museo del Prado. 124 pp.

Weise, G. (1925). Spanische Plastik Aus Sieben Jahrhunderten. Reutlingen: Gryphius. 251 pp.

YArZA, J. (1987). "Definición y ambigüedad del tardogótico palentino», en VV. AA. Actas del I Congreso de Historia de Palencia. Castillo de Monzón de Campos, 3-5 diciembre de 1985. Palencia: Diputación Provincial. pp. 23-60.

Yarza, J. (1993). "Cuatro escenas de la vida de Santa Úrsula», en VV. AA. Un mecenas póstumo: el legado Villaescusa: adquisiciones 1992-1993. Madrid: Museo del Prado. pp. 12-19.

Zalama, M.A. (1987). «Portadas retablo renacentistas en. Valladolid y Palencia». Boletín del Seminario de Estudios de Arte y Arqueología. 53: 312-316. 


\section{ANEXO DOCUMENTAL}

\section{Contrato para la realización del sepulcro de los iit marqueses de Poza}

Información recopilada por Esteban García Chico en Papeletas de Historia y Arte. Palencia: Artes Gráficas Mazo, 1951, pp. 133-137 y por Anastasio Rojo Vega en el blog https://investigadoresrb. patrimonionacional.es/node/9060.

Doña Francisca Enríquez de Cabrera [...] biuda del señor don francisco de rojas marques de poça del consejo de estado y guerra de su magestad [...] hizo concierto con Cristóbal Velázquez, su hijo Francisco Velázquez y Juan de Muniategui, maestros ensambladores; y Antonio de Arta, maestro cantero, sobre una capilla en Palencia. [...] que los dichos cristobal y francisco velazquez juan de monategui y antonio de arta como tales maestros y escultores toman a su cargo y riesgo y debajo de la dicha mancomunidad y renunciaciones de ley se obligan de acer y que aran en la capilla mayor del monesterio de san pablo de la ziudad de Palencia de la orden de santo domingo cuya fundaçion y patronazgo es de los dichos señores don francisco de rojas y dońa francisca enriquez su muger marques y marquesa de poça un nicho en que en ancho y alto sea igual con el que esta hecho en la dicha capilla al lado del ebangelio donde estan los bultos de los señores marques y marquesa de poça don juan de rojas y dońa maria sarmiento y como lo demuestra una traça que dello esta hecha y firmada del señor contador juan de sabanza en nombre y por la dicha seńora marquesa [...] de la forma y con las condiciones siguientes: primeramente an de acer un çocalo de marmol blanco y negro de las canteras de estremoz como lo demuestra la dicha traça yten an de açer encima deste çocalo un pedestal sobre que cargan las colunas con su basa y sotabasa de jaspe colorado y los entrepaños de marmol blanco y negro como lo muestra la dicha traça yten que la piedra donde a de ir el letrero a de ser de marmol negro yten an de acer cuatro colunas de marmol blanco y negro de doce pies de alto con sus basas y capiteles de bronçe dorado y entre coluna y coluna an de echar un entrepaño de marmol negro con sus fajas de jaspe y los traspilares de jaspe todos con sus capiteles y basas de bronçe yten que el dicho nicho a de tener siete pies de ancho y quatro de ondo desde el bibo del traspilar guarnecido con sus pilastras como lo muestra el alçado y plata de la traça mas a de llebar por la parte de adentro del nicho quatro pilastras de jaspe enbutidas de marmol negro y entre pilastra y pilastra guarnecido de jaspe y marmol y las pilastras an de llebar la inposta resaltada como lo muestra la traça y de pilastra a pilastra an de cerrar dos arcos de jaspe el delantero que sale a la capilla con sus molduras como lo muestra la traça y el de adentro sin molduras las dobelas destos arcos an de ser inbutidas de marmol muy bien ajustado y pegados con su betun de fuego yten an de acer el cornizamento desta obra de orden dorica con las gotas del alquitrabe de bronçe dorado y los trilifos del friso de bronçe dorado con metopas de marmol y su alquitrabe y corniza de jaspe como lo muestra la traça mas an de acer sobre la corniza un pedestal de jaspe y marmol como lo muestra la traça yten an de acer e elijir sobre este pedestal sus pilatras de jaspe enbutidas de marmol con basas y capiteles de bronçe dorado con sus basas y arbotantes yten an de acer un escudo de armas con su corona con las armas que les señalaren y su feston alrededor muy bien adornado yten an de acer su frontespiçio con sus bolas y pedestales de jaspe como le muestra la traça yten an de acer debajo del dicho nicho una caja con su arco donde a de cargar la figura que quepa un onbre a andar alla dentro y la entrada sera quitando una piedra del çocalo para meter un ataud la qual dicha obra y las piedras della an de ser de jaspe colorado de las canteras de espeja y el marmol blanco y negro de las canteras de estremoz que es en el reino de portugal todo ello muy bien enbutido y labrado e ilustrado a contento de la persona que para ello señalare la seńora marquesa y toda la obra a de ir muy bien asentada con sus grapas donde fuere necesario y los enbutidos con su betun de fuego pegados y muy bien ajustados yten mas an de acer los dichos maestros un bulto de siete pies de alto puesto en pie de la figura del señor marques con el adorno que muestra la traça de marmol de las canteras de estremoz de una piedra sola sin añadidura ninguna y sin pico que la yenda por ninguna parte ni respentadura 
ni entrecascado y con su almuada de marmol blanco y las borlas de bronçe doradas y el sitial de marmol blanco todo ello conforme al retrato que esta en la dicha traça y a contento de su señoria yten que encima del frontespicio se a de acer un pedestal y encima una cruz de jaspe de quatro pies de alto conforme a la traça yten que todos los claros que sobraren a los lados deste nicho se an de inchir de piedra labrada como esta lo demas de la capilla yten que en el pedestal de debajo del nicho en la lamina de marmol negro se a de esculpir en letras de bronce doradas metidas en la misma lamina el letrero que se sigue «aqui yace don francisco de rojas marques de poça de los consejos destado y guerra de los señores reyes don felipe segundo y terçero falleçio a trece de henero de mil y seiscientos y quatro hiço esta obra doña francisca enriquez de cabrera su muger hija de los seńores almirante de castilla duques de medina de rioseco y condes de modica don luis enriquez y dońa ana de cabrera y tanbien hiço la reja y doto la misa mayor conbentual en seiscientos ducados en cada un año perpetuos con que los trecientos ducados se an de enplear en cada un ańo para aumento de la dicha memoria y dotacion acabose tal dia" y que las letras del dicho letrero an de ser del tamańo y de la manera questan escritas en un patron de papel de marca mayor y esta firmado del dicho señor contador juan de sabanza y de los tres maestros y del presente scrivano que queda en poder del dicho contador yten que el padre prior del dicho conbento a de dar parte acomodada y cerrada donde se labre y guarde el jaspe y marmol para la seguridad y comodidad de la obra yten que los dichos maestros se encargan y se obligan quando començaren la dicha obra a cubrir la rela con lienço de manera que no resciba dańo con el polbo y si lo rescibiere a de ser a su costa y por su quenta lo an de adreçar y cubrir la dicha reja yten que los dichos maestros an de quitar los antepechos que estan en la capilla y alargar las gradas y escodar las demas para que parezcan todas nuebas y todo lo demas que fuere necesario para asentarlas lo an de acer los dichos maestros a su costa sin que la dicha señora marquesa les aya de dar cosa alguna de materiales ni manos para ello las quales dichas gradas an de estar hechas para el dia de todos santos primero que biene deste presente año de mil y seiscientos y nuebe yten que toda la dicha obra la an de acer sin perjuicio ni daño de lo que esta hecho y quedando todo el edificio y obra con la seguridad y firmeça necesaria por quanto se a de abrir para acer la dicha obra y tomar parte de los dos arcos por quanto no cave en uno que lo que sobrare de los dichos dos arcos se a de cerrar de la misma piedra y el nicho que se ace de nuebo a de imitar en alto y ancho sin tener mas ni menos al que esta hecho enfrente del y al ornato del yten que toda la dicha obra conforme a la dicha traça y condiciones y en la manera que dicha es la daran hecha y acabada en toda perficion dentro de dos años contados desde oy dia de la fecha desta escritura en adelante yten que toda la dicha obra conforme a la dicha traça y condiciones y en el dicho tiempo la an de acer los dichos maestros a toda su costa ansi de manos como de materiales a los plaços que iran declarados sin que su seńoria sea obligada a darles otra cosa alguna yten que si los dichos maestros dieren acavada la dicha obra y puesta en perficion antes de los dichos dos ańos por cada mes que la anticiparen se les aya de dar cien ducados mas del preçio questa concertado yten con condiçion que si los dichos maestros no cunplieren pusieren y asentaren y acavaren la dicha obra en perficion dentro de los dichos dos años se les aya de bajar mil ducados del dicho precio y que demas desto su seńoria pueda poner a costa de los dichos maestros personas que lo acaben a contento de su señoria y por el precio en que se concertare [...] yten con condicion que despues de acabada y puesta en perficion la dicha obra la dicha señora marquesa pueda poner persona o personas a satistafion de su seńoria lapidarios y escultores que sepan de traça y arquititura para que bean si en todo an cunplido con la traça y condiciones [...] nonbrando ansimismo los dichos maestros de su parte personas del dicho arte para que informen a los que nonbrare la dicha seńora marquesa yten que los dichos ocho mil ducados del precio de la dicha obra la dicha señora marquesa se los a de pagar en esta manera dos mil ducados luego para ir a las canteras y estando toda la piedra en la obra para començar a labrar otros dos mil ducados y estando la mitad de la obra asentada otros dos mil ducados y los otros dos mil ducados restantes se les an de pagar estando la obra acavada y dada por buena por las personas que su señoria nonbrare lo qual pagara su seńoria llanamente de contado [la marquesa garantiza el pago con una serie de juros y rentas...] [por 
su parte, los maestros dan por garantía...] yten una casa quel dicho cristobal velazquez tiene junto a la calle de la cruz que ace esquina con la dicha cruz y con casas de esteban del peso en que bibe y unas tierras de pan llebar con sus eras camino de medina del campo de cinco yguadas y un cercado junto al monesterio del corpus cristi desta ziudad de seus yguadas yten un majuelo del dicho francisco velazquez de trece alanzadas que tiene do dicen el ojo de nalda que linda con majuelo de muńoz y el camino de renedo yten la mitad de las casas en que bibe el dicho juan de muniategui en la calle del sacramento desta ciudad que es suya [...] 



\section{REVISORES}

Antonio Albardonedo Freire

Jesús Rojas-Marcos González

Carmen de Tena Ramírez

María de Los Ángeles Fernández Valle

Claudio Petit Laurent Charpentier

Alejandra Palafox Menegazzi

Ivan Sergio

Emilce Nieves Sosa

Consuelo Soler Lizarazo

Pompeyo Pérez Díaz

María Inmaculada RodríGuez MoyA

Victor Mínguez Cornelles

Juan Chiva Beltrán

Pedro Zamorano Pérez

Carmen Milagros González de Chávez

Ana María Quesada Acosta

Ricardo Anguita Cantero

Valeria CAMPORESI

Kepa Sojo

Esther Torrado Martín-Palomino

Simonne Teixera

Aline dos Santos Portilho

Juan IgnÁCio Brizuela 
INFORME DEL PROCESO EDITORIAL DE ARHA 0 (2020)

El equipo de dirección se reunió virtualmente en los meses de mayo y julio de 2020 para tomar decisiones sobre el proceso editorial del número 0 de ARHA. El tiempo medio transcurrido desde la recepción, evaluación, aceptación, edición e impresión final de los trabajos fue de 6 meses.

\section{Estadística:}

N. ${ }^{\circ}$ de trabajos recibidos: 8 .

N. ${ }^{\circ}$ de trabajos aceptados para publicación: 5 (62,5\%). Rechazados: 3 (37,5\%).

Media de revisores por artículo: 2 .

Media de tiempo entre envío y aceptación: 6 meses.

Los revisores varían en cada número, de acuerdo con los temas presentados. 


\section{ENVÍOS}

Para enviar un artículo o reseña a ACCADERE. Revista de Historia del Arte es imprescindible que se registre en la siguiente dirección: www.ull.es/revistas.

El registro no solo sirve para enviar elementos en línea, sino también para comprobar el estado de los envíos. Los originales remitidos se enviarán en formato Microsoft Word y se publicarán en el idioma en el que se han entregado.

\section{IDIOMAS ACEPTADOS}

Castellano, portugués, inglés, italiano.

\section{TIPOS DE CONTRIBUCIÓN}

\section{A. Artículo}

Manuscritos de entre 15 y 30 páginas (desde el título hasta la última figura, fuente Times New Roman 12 , interlineado 1,5$)$.

Artículos más largos (31-55 páginas) deberán fundamentar la extensión con una carta de justificación.

El resumen tendrá un máximo de 200 palabras y se entrega en uno de los idiomas aceptados y en inglés.

Las palabras clave, hasta un máximo de 8 , se entregan en uno de los idiomas aceptados y en inglés.

\section{B. Nota / Documento}

Manuscritos de 12 páginas como máximo (desde la página del título principal hasta la última figura, fuente Times New Roman, interlineado 1,5).

Una figura y una tabla como máximo.

El resumen tendrá un máximo de 150 palabras y se entrega en uno de los idiomas aceptados y en inglés.

Las palabras clave, hasta un máximo de 4 , se entregan en uno de los idiomas aceptados y en inglés.

\section{Entrevista}

Contribuciones de entre 10 y 12 páginas (desde la página del título principal hasta la última figura, fuente Times New Roman, interlineado 1,5).

\section{RESEÑA}

La extensión será de entre 5 y 7 páginas (desde la página del título principal hasta la última figura, fuente Times New Roman, interlineado 1,5). En el caso de reseñas sobre un conjunto de obras la extensión máxima admitida es de 10 páginas.

En la cabecera figurarán los datos del libro: autor/es (apellidos, nombres), (ed., comp., coord., dir.), título del libro en cursiva, lugar, editorial, año de edición, páginas del libro, y si lleva ilustraciones, etc.

Las reseñas no llevarán bibliografía y si se incluyen algunas notas serán las imprescindibles.

Solo se admitirán reseńas de obras editadas en los tres últimos años.

La revista no se compromete a la publicación de reseńas no solicitadas.

\section{INSTRUCCIONES GENERALES DE FORMATO}

- El formato del archivo deberá ser Microsoft Word.

- Fuente Times New Roman de tamaño 12 para texto, 10 para notas.

- Interlineado a 1,5.

- Páginas numeradas consecutivamente.

- Tamaño de página A4.

- Márgenes de 2,5 cm.

- El artículo llevará el TÍTULO centrado en mayúsculas (letra de tamaño 12). No debe incluirse el nombre y filiación del autor o autores del trabajo, pues esta información se incluirá en los metadatos solicitados por el sistema al subir el archivo.

- A continuación, separado por tres marcas de párrafo (retornos), se incluirán el Resumen en español y las PALABRAS CLAVE; y seguidamente título en inglés (versalita), el AbSTRACT y las Keywords.

- Las notas se colocarán a pie de página con numeración correlativa e irán a espacio sencillo. Las llamadas a notas han de ir siempre junto a la palabra, antes del signo de puntuación. Se recomienda que sean solo aclaratorias y que se incluyan dentro del texto aquellas en las que se citen únicamente el autor, año y página. 
- Asegurarse de que todas las citas se encuentran recogidas en la sección de referencias. Las citas intercaladas en el texto (inferiores a 40 palabras) irán entre comillas bajas o espańolas («...»), en letra redonda. Las omisiones dentro de las citas se indicarán mediante tres puntos entre corchetes [...]. Si en una cita entrecomillada se deben utilizar otras comillas, se emplearán las altas (“...”). Las citas superiores a tres líneas se sacarán fuera del texto, sin comillas, con sangría izquierda $(1,5 \mathrm{~cm})$, en letra de tamańo 10.

- Tablas y figuras en páginas aparte y numeradas. Figuras aparte en formato JPEG, TIFF, PNG o EPS en calidad $300 \mathrm{ppp}$, con pie de foto como se detalla en el ejemplo:

Figura 1. Alessandro Ciccarelli, Vista de Santiago desde Peñalolen, 1853, $85 \times 125 \mathrm{~cm}$,

Pinacoteca Banco Santander, Santiago, Chile.

\section{INSTRUCCIONES GENERALES PARA LAS REFERENCIAS}

\section{A. Referencias en el texto}

Para citar en el texto se utilizará el formato apellido-año usado por APA.

Ejemplos:

- Un autor: (Rossi Pinelli 2014).

- Dos autores: (Argan y Fagiolo 2014).

- Varios autores: (Borrás Gualis et al. 1991).

- Organización: (ICOM 2010).

- Múltiples citas: (Rossi Pinelli 2014; Borrás Gualis 1991).

- Múltiples citas del mismo autor/es en diferentes años: (Rossi Pinelli 2014, 2015, 2018, 1999, 2000, 2002).

- Múltiples citas del mismo autor/es durante el mismo año: (Rossi Pinelli 2014a, 2014b).

B. Listado de REFERENCias

- Se presenta al final del texto.

- Apellidos y luego iniciales del nombre: Argan, G.C., Rossi Pinelli, O.

- Organización alfabética por apellido del autor, cuando hay más de un trabajo por autor, estos se listan cronológicamente.

- El año de la publicación y el volumen son necesarios para todas las referencias.

\section{EJEMPLOS}

LiBros

- Rossi Pinelli, O. (2014). La storia delle storie dell'arte. Torino: Piccola Biblioteca Einaudi. Nuova serie.

- Borrás Gualis, G., Lomba Serrano, C. y Gómez, C. (1991). Los palacios aragoneses. Zaragoza: Caja de Ahorros de la Inmaculada de Aragón.

- Argan G.C., Fagiolo M. (1974). Guida a la storia dell'arte. Florencia: Sansoni.

Capítulo de libro

- Cinelli, N. (2019). «Bajo el bello cielo de Chile. Alessandro Ciccarelli, primer director de la Academia de Pintura en Santiago (siglo XIx)", en Fernández Valle, M.A., López Calderón, C. y Rodríguez Moya, I. (eds.), Pinceles y gubias del barroco iberoamericano. Sevilla: Andavira Editora. pp. 393-403.

Artículo

- Lootsma, H. (2017). «A re-assembled altarpiece by Bernard van Orley». Burlington Magazine, Londres: Burlington Magazine Limited, n. ${ }^{\circ} 159$, pp. 88-98.

\section{RECURSO INFORMÁTICO}

- Cardona, R. (2016). «El hombre perdido: última novela de la nebulosa», Revista de Filología, San Cristóbal de La Laguna: Universidad de La Laguna, n. ${ }^{\circ}$ 34, pp. 41-50. URL: http://webpages.ull.es/publicaciones/ volumen/revista-de-filologia-volumen-34-2016.pdf; consulta hecha el día 29/01/2021.

Los artículos que no se atengan a estas normas serán devueltos a sus autores.

\section{DECLARACIÓN DE PRIVACIDAD}

Los nombres y las direcciones de correo electrónico introducidos en esta revista se usarán exclusivamente para los fines establecidos en ella y no se proporcionarán a terceros o para su uso con otros fines. 
